\title{
Remote Sensing of Suspended Sediment Concentration and Hydrologic Connectivity in a Complex Wetland Environment
}

\author{
Colleen McCormick Long
}

A thesis submitted to the faculty of the University of North Carolina at Chapel Hill in partial

fulfillment of the requirements for the degree of Master of Science in the Department of Geological Sciences.

Chapel Hill

2012

Approved by:

Dr. Tamlin Pavelsky

Dr. Jason Barnes

Dr. Larry Benninger 
(C) 2012

Colleen McCormick Long

ALL RIGHTS RESERVED 


\begin{abstract}
Colleen McCormick Long: Remote Sensing of Suspended Sediment Concentration and Hydrologic Connectivity in a Complex Wetland Environment

(Under the direction of Dr. Tamlin Pavelsky)
\end{abstract}

We use daily MODIS imagery in bands 1 and 2 to monitor suspended sediment and, by proxy, hydrologic recharge in the Peace-Athabasca Delta, Canada from 2000 to present. To identify an appropriate suspended sediment concentration (SSC)-reflectance model, we compare 31 published equations using field observations of spectral reflectance and SSC. Results suggest potential for spatial transferability of such models if they 1) use of a near infrared band in combination with at least one visible band, 2) were developed based on SSCs similar to those in the new site, and 3) are nonlinear. We develop a twelve-year time series of SSC in Lake Athabasca and observe timing and sources of major sediment fluxes. We also track the influx of Athabasca River water to floodplain lakes. In three lakes we identify discharge thresholds required for hydrologic recharge, and we find a significant decline in the threshold exceedence frequency since 1970. 


\section{Acknowledgements}

I am very grateful for the guidance of Dr. Tamlin Pavelsky, whose willingness to share ideas, knowledge, and time made the completion of this thesis possible. Additional reviews from Dr. Jason Barnes and Dr. Larry Benninger further improved the final version of this paper. I also thank Zach Miller, Dr. Larry Benninger, Robert Grandjambe, and the staff of Wood Buffalo National Park for assistance in the field. Funding for this work came from the UNC Department of Geological Sciences Martin Fund and the Geological Society of America (Grant \#9536-11). 
Table of Contents

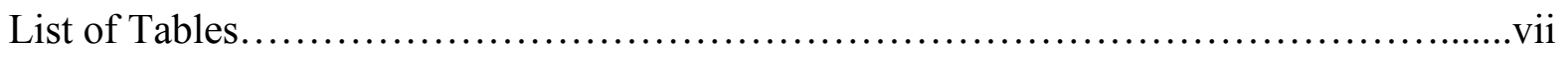

List of Figures..............................................................

Chapter

1. Remote Sensing of Suspended Sediment Concentration and Hydrologic Connectivity in a Complex Wetland Environment...............1

Abstract............................................................

Introduction........................................................

Study Area: The Peace-Athabasca Delta.................................5

Methods.............................................................. 8

Collection of Field Data..........................................8

Collection and Processing of Satellite Imagery....................9

Evaluation of SSC-Reflectance Models...........................11

Analysis of SSC in Lake Athabasca.............................12

Analysis of Floodplain Lake Recharge.............................13

Results

Spatial Transferability of SSC-Reflectance Models...................14

Sediment Dynamics in the Western End of Lake Athabasca............16

Tracking Recharge of Small Floodplain Lakes......................18

Discussion and Conclusions.........................................20 
References.......

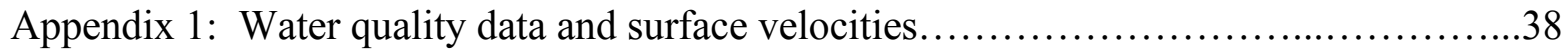

Appendix 2: In situ reflectance measurements.....................................45

Appendix 3: Sediment Area Index time series for floodplain lakes........................52

Appendix 4: Select additional sediment maps and MODIS images........................58 


\section{List of Tables}

\section{Table}

1. Compilation of 31 published SSC-reflectance models

2. Frequency of river discharge threshold exceedence 


\section{List of Figures}

Figure

1. The Peace-Athabasca Delta

2. Athabasca River Discharge, 1970-2011

3. Field data collection sites and study areas

4. Comparison of measured and predicted SSCs for a transect in Lake Athabasca

5. MODIS Reflectance vs. In situ reflectance

6. Analysis time periods and selection method

7. Subset of the 31 tested SSC-reflectance models

8. MODIS-derived sediment maps for the western end of Lake Athabasca

9. Time series of SSC in Lake Athabasca and discharge on the Peace and Athabasca Rivers

10. Athabasca River discharge vs. SSC in Lake Athabasca and in the Athabasca River

11. Athabasca River discharge vs. Sediment Area Index

12. Frequency of threshold exceedence 
Chapter 1:

Remote Sensing of Suspended Sediment Concentration and Hydrologic Connectivity in a Complex Wetland Environment

\begin{abstract}
Maintaining the ecological diversity and hydrologic connectivity of freshwater delta systems depends on regular recharge of floodplains with river water, which can be difficult to observe on the ground. Rivers that form deltas often carry large amounts of suspended sediment, but floodplain lakes and wetlands usually have little sediment in suspension. Remote observation of high sediment water in lakes and wetlands therefore often indicates connectivity with the river network. In this study, we use daily 250-m MODIS imagery in band $1(620-670 \mathrm{~nm})$ and band $2(841-876 \mathrm{~nm})$ to monitor suspended sediment transport and, by proxy, hydrologic recharge in the Peace-Athabasca Delta, Canada. To identify an appropriate suspended sediment concentration (SSC)-reflectance model, we compare 31 published empirical equations using a field dataset containing 147 observations of SSC and in situ spectral reflectance. Results suggest potential for spatial transferability of such models, but success is contingent on the equation meeting certain criteria: 1) use of a near infrared band in combination with at least one visible band, 2) development based on SSCs similar to those in the observed region, and 3) a nonlinear form. Using a highly predictive
\end{abstract}


SSC-reflectance model (Spearman's $\rho=0.95$ ), we develop a twelve-year time series of SSC in the westernmost end of Lake Athabasca, observe the timing and sources of major sediment flux events, and identify a threshold river discharge of $\sim 1700 \mathrm{~m}^{3} / \mathrm{s}$ above which SSC in Lake Athabasca is clearly associated with flow in the Athabasca River. We also track the influx of Athabasca River water to floodplain lakes, and in three of the lakes identify distinct discharge thresholds $\left(1040 \mathrm{~m}^{3} / \mathrm{s}, 1150 \mathrm{~m}^{3} / \mathrm{s}\right.$, and $\left.1850 \mathrm{~m}^{3} / \mathrm{s}\right)$ which result in lake recharge. For each of these lakes, we find a statistically significant decline in the threshold exceedence frequency since 1970, suggesting less frequent recharge during the summer.

\section{Introduction}

Freshwater deltas are among the most biologically productive and ecologically diverse terrestrial ecosystems. To sustain their characteristic complexity, these environments depend on regular recharge with sediment-laden river water, generally through overbank flooding and flow through distributary channel networks (Lesack et al., 1998). Transport and deposition of sediment in deltas shapes the landscape through construction of natural levees, aggradation of wetland areas, and progradation of the delta margin (Syvitski et al., 2009). Moreover, the movement of water and sediment through delta ecosystems is a key mechanism for cycling of nutrients and contaminants (Bloesch, 1995; Hernández-Ayón et al., 1993; Pereira et al., 1996; Owens et al., 2005). Delivery of sediment to deltas worldwide has declined in the last century due to trapping in upstream reservoirs, artificial construction of levees, and impacts of climate change (Kummu \& Varis, 2007; Syvitski, 2008; Syvitski et al., 2005; Vörösmarty et al., 2003). These decreases in the amount and frequency of sediment and water input, as well as constraints on the spatial extent of recharge, can 
substantially impact geomorphic and biogeochemical processes in deltas (Meade, 1996; Yang et al., 2003).

The supply of river water to delta floodplains is largely controlled by hydrologic connectivity, and an understanding of connectivity is therefore critical to assessing a delta's ecological health (Pringle, 2003; Bracken \& Croke, 2007). Defining and quantifying connectivity, however, remain intractable problems in many systems. Metrics used to assess hydrologic connectivity must often be uniquely chosen based on the catchment under investigation (Ali \& Roy, 2010), and many techniques require extensive fieldwork (e.g. Fennessy et al., 2004; Jencso et al., 2009; Wolfe et al., 2007). The information these methods provide can be limited in complex freshwater deltas where small changes in water level are highly consequential, low slopes lead to frequent reversals in flow direction, and connections form through small channels or diffuse transport processes. Some previous studies have used remote sensing to monitor connectivity and effectively bypass the problems associated with in situ assessments, but most results show general spatiotemporal variations in the degree of connectivity without fully constraining timing and magnitude of specific recharge events (e.g. Mouchot et al., 1991; Pavelsky \& Smith, 2008; Smith \& Alsdorf, 1998).

Using remote sensing to monitor the presence of high-sediment river water in floodplain lakes compliments other methods of assessing connectivity by tracking specific recharge events, even in complex delta systems (Pavelsky \& Smith, 2009). Because the suspended sediment concentrations (SSCs) in delta-forming rivers generally exceed those in floodplain lakes and wetlands, high-sediment water observed outside of the river often indicates connectivity to the river. Sediment can therefore be used as a tracer of hydrologic 
recharge in freshwater deltas. Because deltas often have highly variable flow conditions and many lakes and wetlands, frequent and long-term in situ measurements of SSC can be prohibitively difficult to obtain. Remote sensing is not subject to the challenges of in situ data collection, and since the 1970s has been used to quantify SSCs in surface waters (Ritchie et al., 1976).

The amount of sediment in water directly affects the reflectance of solar radiation in the visible and near-infrared portions of the spectrum; in general, the more sediment in suspension, the higher the reflectance (Curran \& Novo, 1988; Ritchie, 2003). However, the exact form of the relationship between SSC and reflectance also depends on the mineralogy, color, and size of the sediments (Novo et al., 1989). These factors can be highly variable in natural environments, and therefore the applicability of an SSC-reflectance relationship is generally assumed to be limited to the setting in which the data were collected. Most studies develop unique relationships by relating field measurements of SSC to reflectance data from satellite imagery (for examples, Table 1). This purely empirical approach restricts development of SSC maps from satellite imagery on regional and global scales. A limited number of previous studies have explored whether models developed in one location are spatially transferable to another (Holyer, 1978; Ritchie \& Cooper, 1991; Topliss et al., 1990) and suggest that transferability may be possible. However, these studies have focused on low SSCs (Holyer, 1978) and a limited range of wavelengths (Ritchie \& Cooper, 1991; Topliss et al., 1990), and they do not incorporate work from the past two decades. Development of one or more spatially transferable models would be of great scientific and practical interest, but no recent work has compared the applicability of existing models in a common natural setting. 
The Peace-Athabasca Delta (PAD) (Figure 1), located in northeastern Alberta, Canada, is an ideal setting for studying the transferability of SSC-reflectance models. It exhibits a wide range of SSCs, receives sediment from more than one source, and is often cloud-free during the summer. Previous work has demonstrated that robust statistical relationships between SSC and remotely sensed reflectance can be constructed in the PAD (Pavelsky \& Smith, 2009). Furthermore, recent alterations to flow on the Peace and Athabasca Rivers associated with changing climate and human impacts have raised questions about how hydrologic recharge in the PAD may be changing. Remote sensing of spatial and temporal variations in SSC can help address these questions.

This study is comprised of three major components. We first explore the applicability of published, site-specific SSC-reflectance models to the PAD in order to understand the extent to which these relationships are spatially transferable. We then use a highly predictive model to distinguish the source and timing of major sediment flux events in the western end of Lake Athabasca, which forms the eastern boundary of the PAD. Finally, we use remote sensing of SSC to determine discharge thresholds above which river water recharges small floodplain lakes in the PAD and examine changes in the exceedence frequency of these thresholds.

\section{Study Area: The Peace-Athabasca Delta}

The Peace-Athabasca Delta is a hydrologically complex and ecologically diverse freshwater delta formed by the confluence of the Peace, Athabasca, and Birch Rivers near the western end of Lake Athabasca (Figure 1). The three intersecting river deltas cover $\sim 5,200$ $\mathrm{km}^{2}$, making the PAD one of the world's largest freshwater deltas. It has been named a 
United Nations Educational, Scientific, and Cultural Organization (UNESCO) World Heritage site and a Ramsar Convention Wetland of International Importance because of its biological significance and role as the largest alluvial-wetland habitat in the region. The delta provides a habitat for migratory birds and land mammals including moose, black bear, and wood buffalo (Prowse \& Conly, 2002). The wildlife and vegetation in the PAD also have cultural and historical importance to indigenous residents in the region, including the Athabascan Chipewyan and Mikisew Cree First Nations. A large portion of the delta ( $\sim 80 \%)$ is protected within Canada's Wood Buffalo National Park. However, the PAD depends on the rivers that flow into it to support its aquatic and terrestrial habitats, and natural or anthropogenic changes in river flow far upstream can have significant effects on the delta.

During normal flow conditions, the main source of recharge to the delta is the northflowing Athabasca River, and drainage is northward through several distributaries to the Peace River and, ultimately, the Slave River. However, if the water level on the Peace River is higher than that of Lake Athabasca, flow reverses along the distributary channels that connect the Peace River to the lake. The relationship between flow on the Peace River and the hydrology and ecology in the Peace sector of the delta have been addressed by several studies since the 1970s in response to the completion of the W.A.C. Bennett dam, which regulates flow from the headwaters of the Peace River (Farley \& Cheng, 1986; Leconte et al., 2001; Peters \& Prowse, 2001; Prowse \& Demuth, 1996). There is some evidence that flow regulation has decreased the frequency of ice jam flooding on the Peace River, which is the primary mechanism of very large-scale flooding in the PAD (Beltaos et al., 2006a; Beltaos et al., 2006b). Between 1959 and 1976, major ice-jam flooding occurred four times in seventeen years, but between 1976 and the present (36 years), the only major events occurred 
in 1996 and 1997 (Beltaos et al., 2006a). As a result, the dominant sources of recharge in recent decades have been springtime ice jam floods and summertime high water events on the Athabasca River (Pavelsky \& Smith, 2008; Peters et al., 2006; Töyrä \& Pietroniro, 2005).

Since the 1970s, summer discharge on the Athabasca River has declined (Figure 2) due to both natural and anthropogenic forces. Increased evapotranspiration and diminished contributions from snowpack and glaciers in the Canadian Rockies, likely related to anthropogenic climate change, are responsible for much of this decline (Schindler, 2001; Schindler \& Donahue, 2006). Increasing water withdrawals for industrial operations in the Alberta Oil Sands (located on the Athabasca River about $250 \mathrm{~km}$ upstream from the PAD) could add to future discharge declines (Schindler \& Smol, 2006), though winter, not summer, is the key time of year for assessing the ecological impacts from oil sands withdrawals (Andrishak \& Hicks, 2011). The effects of this decline on hydrologic recharge in the PAD are largely unknown. In particular, the thresholds of discharge required to deliver river water to ecologically important floodplain lakes remain unquantified.

Recharge of floodplain lakes in the Athabasca sector of the PAD occurs when flow on the Athabasca River rises sufficiently to either overtop its levees or reverse flow on the small channels that ordinary are directed into the river from floodplain lakes. Except during recharge events, SSCs are higher in the Athabasca River than in floodplain lakes. As a result, the presence of high sediment water in a floodplain lake represents, under most circumstances, an input of river water. A detailed time series of SSCs in these lakes would provide information about how hydrologic recharge in the PAD is responding to the decreases in discharge on the Athabasca River. Pavelsky and Smith (2009) used satellite images to capture episodic recharge of floodplain lakes in the Athabasca sector of the delta 
and related timing of recharge to discharge on the Athabasca River. We expand on this work by examining SSC in Lake Athabasca and determining the threshold discharge values required for hydrologic recharge of floodplain lakes.

\section{Methods}

\section{Collection of Field Data}

During a field season from June $20^{\text {th }}$ to July $7^{\text {th }}, 2011$, we measured spectral reflectance and water quality in lakes, rivers, and distributary channels in the PAD. In-situ measurements of temperature $\left({ }^{\circ} \mathrm{C}\right)$, color dissolved organic matter concentration $(\mu \mathrm{g} / \mathrm{L})$, turbidity (NTU), chlorophyll content $(\mu \mathrm{g} / \mathrm{L})$, and specific conductivity $(\mu \mathrm{S} / \mathrm{cm})$ were collected using a Eureka Manta Multiprobe a total of 147 times at 71 unique locations (Figure 3). Multiprobe measurements were collected at two-second intervals for at least three minutes and averaged to obtain one value for each variable per site. Surface flow velocity was measured at most river locations (67 total measurements) using a stopwatch, a handheld GPS, and a small drogue (following Pavelsky and Smith, 2009). These datasets augment water quality data collection in the PAD beginning in 2006 and continuing in 2007, 2010, and now 2011. The 2006-2007 data is archived at the Oak Ridge National Laboratory Distributed Active Archive Center for Biogeochemical Dynamics and is available at http://daac.ornl.gov//HYDROCLIMATOLOGY/guides/PAD.html.

Spectral reflectance from the water surface was measured at $1 \mathrm{~nm}$ intervals between 350 and $1025 \mathrm{~nm}$ at each of the 147 field sites using an ASD FieldSpec $₫ 3$ Portable Spectrometer with an attached OL 731 Smart Detector for solar irradiance measurements. A white reference measurement was obtained from a Spectralon ${ }^{\circledR}$ white standard at each 
location prior to collection of reflectance spectra to account for changes in lighting conditions between sites. Three reflectance measurements were collected at each location and then averaged to obtain one reflectance value per wavelength per site.

Suspended sediment concentrations were also measured at each site. We collected $275 \mathrm{~mL}$ water samples from the top $\sim 15 \mathrm{~cm}$ of the water column. Water samples were filtered onto pre-weighed $1.2 \mu \mathrm{m}$ Millipore cellulose filters using a vacuum filtration system. After filtration, the filters were dried in an oven at $100^{\circ} \mathrm{C}$ for 30 minutes and then reweighed on a high precision balance to determine the weight of total suspended matter. This weight divided by the sample volume yielded the suspended sediment concentration $(\mathrm{mg} / \mathrm{L})$.

\section{Collection and Processing of Satellite Imagery}

Previous studies have used high resolution satellite imagery to track variations in SSC in wetland environments (e.g. Doxaran et al., 2002; Mertes et al., 1993; Ritchie \& Cooper, 1991). Because of infrequent temporal sampling, however, such imagery is unsuitable for tracking SSC in the PAD on daily to weekly timescales. We therefore use imagery from NASA's two Moderate-resolution Imaging Spectroradiometer (MODIS) sensors, which each provide daily observations. Many previous studies have found that a combination of red and near-infrared bands, such as MODIS band 1 (red; 620-670 nm) and band 2 (near-infrared; 841-876 nm), results in robust quantification of SSC (e.g. Doxaran et al., 2009; Holyer, 1978; Novo et al., 1989). Additionally, MODIS bands 1 and 2 have sufficiently high spatial resolution $(250 \mathrm{~m})$ in the red and near-infrared bands to detect moderate-sized floodplain lakes such as those found in the PAD. 
Daily MODIS Level 2G Aqua and Terra scenes (MOD09GQ) collected over the PAD were downloaded using NASA's Warehouse Inventory Search Tool (http://wist.echo.nasa.gov) for every summer (May-September) from 2000 through 2011. A total of 3,672 images were obtained. The Aqua satellite was not launched until 2002, and therefore for 2000-2002 only one MODIS-Terra image per day is available. All MODIS Level $2 \mathrm{G}$ scenes are radiometrically and geometrically corrected for variations in sun and sensor angle and atmospheric conditions. Scenes were projected into UTM Zone 12N/WGS 84 , and the dataset was automatically filtered to remove scenes where the PAD is more than $30 \%$ cloud covered based on a band 1 reflectance threshold of 0.15 (following Chen et al., 2009). Elimination of cloudy images yielded 1,620 total images suitable for analysis.

Most data collection points in PAD rivers are not visible in MODIS imagery because the spatial resolution is too coarse. Among the 147 field data collection points, though, is a twenty-three point transect in the western end of Lake Athabasca, and MODIS pixels corresponding to these points are free of land contamination (Figure 4a). We use data from these points to directly validate MODIS-derived reflectance and SSC against field observations. Reflectance data was extracted from MODIS bands 1 and 2 for the 23 transect points, and comparison of the Band 2/Band 1 ratio with same-day in situ reflectance at the same wavelengths shows a high correlation $(\mathrm{r}=0.91)$ and little bias $(p=0.08$ using a paired Student's $t$ test) (Figure 5). A ratio is used for this comparison to account for atmospheric variations over short spatial scales that are not addressed by the large-scale corrections applied to the MODIS images. The high correlation suggests that in situ reflectance can be used to test the applicability of empirical SSC-reflectance models to the PAD, and models developed and tested using in situ data can also be applied to MODIS imagery. 


\section{Evaluation of SSC-reflectance models}

In order to determine if an existing SSC-reflectance model can be applied in the PAD, we evaluate the spatial transferability of 31 published SSC-reflectance empirical relationships representing a range of hydrologic environments including rivers, inland lakes, estuaries, deltas, and bays. Some models predict turbidity instead of SSC, but as in many discussions of remote sensing of SSC (e.g. Duane Nellis et al., 1998; Wass et al., 1997) we treat both metrics interchangeably. We use 147 in situ spectral observations from the PAD to estimate SSC using each model and compare the results against in situ SSC measurements. Because the relationships often contain outliers and are sometimes non-linear in form, Spearman's $\rho$ (Spearman, 1904), a nonparametric test of correlation, is a more appropriate measure of covariance in this case than is Pearson's r. Collectively, the models in Table 1 were developed using SSCs from $<10$ to $2250 \mathrm{mg} / \mathrm{L}$, but most individual studies are limited to a narrow range of concentrations. The 147 field measurements of SSC in the PAD range from 3.9 to $3602 \mathrm{mg} / \mathrm{L}$, and no previous work has tested the applicability of SSC-reflectance models across such a wide range of concentrations.

Some models predict SSCs that are highly linearly correlated with measured values but are numerically dissimilar. In order to improve these models' predictive capacity, we perform linear regressions between measured and modeled values and divide the modeled values by the slope of the regression line. These scaling factors may be required in part because of physical differences in the sediment color and grain size among different locations. It is also possible that in some studies reflectance is scaled differently (e.g. as a percent, a proportion, or between 0 and 255), and this is not reported in all cases. 


\section{Analysis of SSC in Lake Athabasca}

Among the most highly predictive models is one developed by Doxaran et al., (2009) specifically for MODIS data (see section 4.1). We use this model to analyze sediment dynamics in the western end of Lake Athabasca using MODIS imagery from summers 20002011. To monitor time series of sediment input to Lake Athabasca from the Peace and Athabasca Rivers, we establish two virtual sediment gauges in the western end of Lake Athabasca: one at the terminus of the Athabasca Delta, and a second on the north shore of Lake Athabasca in an area that generally receives high sediment water only from the Peace River (Figure 3). To create these virtual gauges, we quantify SSC for three horizontally adjacent pixels at each location and then use the median value to represent the SSC. We remove images where any of the six gauge pixels are cloud covered (Band $1>0.15$ ). Previous work suggests that SSC-reflectance models are time invariant in a localized environment so long as the source of sediment remains the same (Dekker et al., 2001; Ritchie, 2003), and we use the scaled Doxaran et al., 2009 equation to develop time series of SSC at both virtual gauges for each summer from 2000-2011 with daily to weekly temporal resolution (on average, $\sim 40 \%$ of days per summer were suitable for inclusion).

We compare the SSC time series from the two virtual gauges to daily river discharge measurements on the Peace and Athabasca Rivers. River discharge data was obtained from Environment Canada for the gauge stations Athabasca below McMurray (Station ID: 07DA001) and Peace at Peace Point (Station ID: 07KC001). We apply a three-day lag to the Athabasca River discharge data to account for the $\sim 250 \mathrm{~km}$ distance between the gauge and the PAD. The optimal lag of three days is based on 1) calculations with surface flow velocity measurements in the Athabasca River and the distance to the gauge, and 2) regressions 
between 84 SSC measurements in the Athabasca River and river discharge with 0, 1, 2, 3, and 4 day lags. The three-day lag gives the highest $\mathrm{R}^{2}$ value $(0.88)$ in the regressions. The gauge for the Peace River is about $155 \mathrm{~km}$ away from Lake Athabasca, but because flow dynamics are complicated and often reverse in this reach of the river, we were unable to determine a consistent lag. Instead, we use same-day discharge for the Peace River.

\section{Analysis of Floodplain Lake Recharge}

We manually select six floodplain lakes that are consistently visible in MODIS images (Figure 3) to determine Athabasca River discharge thresholds above which river water is consistently delivered to floodplain lakes in the Athabasca sector of the PAD. We are unable to quantify SSCs in these lakes with the model used in Lake Athabasca because the spatial resolution of MODIS results in mixed pixels contaminated by vegetation or bare soil in most of the small floodplain lakes. Instead, for each clear-sky MODIS image we use a binary metric to monitor Sediment Area Index (SAI), the proportion of lake area containing high sediment water (following Pavelsky and Smith 2009). To calculate SAI, we create individual masks of each lake, and remove images in which any masked pixel is contaminated by cloud. For each lake in each remaining image, we count the number of water pixels (defined as MODIS Band $2<0.05$ ) and the number of high sediment water pixels (defined as MODIS Band $1-$ Band $2 \geq 0.01$ ). The sizes of the lakes vary temporally, and analyses for each lake are limited to days when lake area exceeds $0.25 \mathrm{~km}^{2}$ (4 inundated pixels). The number of high-sediment water pixels divided by the total number of water pixels yields the SAI. 
We compare the SAI time series for each lake to discharge on the Athabasca River on days during the rising limb of the first major summertime hydrograph peak. These events (one per year) are found by identifying all points of inflection on the hydrograph and then selecting the first event after June $1^{\text {st }}$ when discharge increases by at least $60 \%$ between two inflection points (for example, Figure 6). As water rises in the Athabasca River, it recharges the floodplain lakes at specific stage thresholds, but once recharge has begun the sediment and water dynamics become much more complex. As such, it is during this first summertime high water event that we are most likely to cleanly identify a recharge threshold. After discharge reaches a maximum, the decline in river discharge and the decline in SSC in the lake do not happen at the same rate, so only the rising limb of the peak is used here. We do not consider peaks before June $1^{\text {st }}$ to avoid the effect of early spring floods related to ice jams, in which water levels, sediment concentrations, and river discharge are often decoupled. The timing and duration of each event are shown in Figure 6. In 2001, we manually extend the analysis period by 4 days because of a one-day $9 \%$ decline during the rising limb of the hydrograph.

\section{Results}

\section{Spatial Transferability of SSC-Reflectance Models}

Our results confirm that it is possible to predict SSCs in the PAD using models developed elsewhere; several models produce estimates of SSC that are highly correlated with our validation dataset (Table 1). Among the highly predictive models, the form of the best-fit relationship between observed and predicted SSCs varies, and it often has a power law, rather than a linear, form (Figure $7 \mathrm{~b}, \mathrm{c}, \mathrm{f})$. The model from Doxaran et al. (2009) is the 
only one to produce values that are linearly correlated with the validation dataset across the entire range of SSCs observed in the PAD (Figure 7a). This equation, with a scaling factor of 2.9 applied, accurately predicts SSCs using both in situ reflectance measurements and satellite-based reflectance from MODIS Terra and Aqua (Figure 4b). Comparing measured SSCs to those predicted with this model results in a better R-squared value for the PAD (0.94) than for the Gironde Estuary (0.89), where the model was developed. Some other models produce values that are linearly correlated with the validation dataset at low concentrations (i.e. $<\sim 200 \mathrm{mg} / \mathrm{L}$ ), but become nonpredictive at higher concentrations (Figure $7 \mathrm{~d}, \mathrm{e})$. For all cases in which the best-fit relationship is linear, application of a correction factor based on the slope of the linear regression between the observed and modeled data is necessary to reproduce observed SSC values.

Although some models do accurately predict SSCs in the PAD, values from the majority of the models do not closely match the validation dataset. Some produce negative values for SSC or turbidity (e.g. Fraser, 1998; Song et al., 2011; Islam et al., 2001; Hellweger et al., 2006) (Figure 7f), others give values orders of magnitude different from our measurements (e.g. Aranuvachapun \& Walling, 1988; Dekker et al., 2001; Keiner \& Yan, 1998; Lathrop et al., 1991; Hellweger et al., 2006), and many are poorly correlated with field measurements. Differences in mineralogy, sediment color, and sediment size can likely explain some of the limited predictive power of these models in the PAD, but it is surprising that many models offer no predictive capacity given the positive relationship between SSCs and spectral reflectance that forms the basis for all of the models.

Comparing the successful models to those that are ineffective suggests three main factors which influence the predictive ability of any given model and increase the potential 
for spatial transferability: 1) the use of a combination of a near infrared band with one or more visible bands, 2) development based on SSCs with a maximum similar to the maximum SSC observed in the PAD, and 3) a nonlinear equation form. The six best models (all with $\rho \geq 0.95$ ) were developed using maximum SSCs of at least $1000 \mathrm{mg} / \mathrm{L}$ and a combination of reflectance in a near infrared and a visible band. The seventh best, though calibrated for less turbid waters, also uses a near infrared band along with visible bands. Of the remaining 24 models, 16 use only a single band, 7 use a combination of bands but do not include a near infrared band, and 1 uses a combination of bands not including a visible band. Finally, out of the nine linear equations tested, only one is in the top ten (Fraser 1998), suggesting that nonlinear models are preferable for modeling SSCs in the PAD.

Our results indicate that spatial transferability of a model is most likely to be successful if the model meets all three proposed criteria. Models that meet only one of these criteria (e.g. they predict high SSCs using one band alone, or have a nonlinear form but were developed to model only low SSCs) produce weaker correlations. Strong performance of a model in predicting SSCs in the PAD does not indicate universal transferability, but the characteristics of high-performing models identified here can be used to guide model selection in environments where in situ measurements are unavailable to calibrate sitespecific relationships.

\section{Sediment Dynamics in the western end of Lake Athabasca}

To understand the dynamics of water input to Lake Athabasca by the Peace and Athabasca Rivers, we created daily sediment maps of the westernmost end of the lake (Figure 8). From the maps, we can clearly detect both the spatial extent and the source of 
sediment-laden river water input to the lake. We can also distinguish the source of river water delivered to the lake using virtual sediment gauges near the lake's two sources of inflow (i.e. the Peace and Athabasca Rivers) (Figure 4). Comparison of SSC time series from these two locations (Figure 9) reveals temporally separate peaks in SSC indicating the source of river water during major flux events. The Athabasca River always flows into Lake Athabasca, but we also identify two instances, in May 2007 and July 2011, where peaks in SSC at the northern shore of the lake indicate inflow of Peace River water.

There is an observable relationship between the timing of significant peaks in SSC in Lake Athabasca and peaks in Athabasca River discharge (Figure 9). Parallels between fluctuations are difficult to detect for small variations in SSC and at low discharge, but the largest peaks in discharge do cause peaks in SSC, most notably in 2001, 2007, and 2011. To better understand the relationship between these two variables, we examine data from the rising limb of the first summertime hydrograph peak, the same metric used to identify inflow thresholds for small lakes (Figure 6). As with small lakes, it is during these events that SSC in Lake Athabasca is most likely to reflect river discharge instead of wind, biological activity, or other confounding variables. Results suggest an Athabasca River discharge threshold of $\sim 1700 \mathrm{~m}^{3} / \mathrm{s}$ at which Lake Athabasca SSCs near the Athabasca Delta begin to increase dramatically from $\sim 200 \mathrm{mg} / \mathrm{L}$ to a maximum of $1085 \mathrm{mg} / \mathrm{L}$ at an Athabasca River discharge of $\sim 3200 \mathrm{~m}^{3} / \mathrm{s}$ (Figure 10). Our compilation of 12 years of near-daily data shows that at discharges less than $\sim 1700 \mathrm{~m}^{3} / \mathrm{s}$, SSCs remain below $\sim 100 \mathrm{mg} / \mathrm{L}$ and are uncorrelated with Athabasca River discharge.

In order to determine the sensitivity of this result to the SSC virtual gauge location, we also measured SSCs at locations closer to and further from the margin of the Athabasca 
Delta. The relative values of SSC varied predictably (i.e. higher closer to shore and lower out in the lake), but at all locations the same discharge threshold of $\sim 1700 \mathrm{~m}^{3} / \mathrm{s}$ was apparent. Such a threshold is not observed between SSCs in the Athabasca River and river discharge, however. In this case, the variables are linearly correlated $(\mathrm{r}=0.94)$ even at low discharges (Figure 10). Finally, we examined the equivalent dataset for the Peace River and find no correlation between river discharge and SSC at the Peace River virtual gauge. This is likely because input of Peace River water depends on the relative levels of the river and Lake Athabasca and not only on river discharge.

\section{Tracking Recharge of Small Floodplain Lakes}

Athabasca River water is input to Lake Athabasca under all flow conditions, but summertime recharge of ecologically important floodplain lakes occurs only when river stage is sufficiently high. To identify discharge thresholds which consistently initiate recharge in individual lakes, we compare Athabasca river discharge during the time periods identified in Figure 6 with the Sediment Area Index of six floodplain lakes consistently visible in MODIS imagery (Figure 11). Positive relationships between Athabasca River discharge and SAI are apparent in Lakes 1, 2, and 3. For each of these lakes, there is a distinct discharge threshold above which there is always high sediment water present and below which there is little to no high sediment water. We know from field observations that these three lakes are hydrologically connected to the Athabasca River through small distributary channels which sometimes, but not always, flow into the lakes. Often, water flows very slowly out of the lakes and back to the river. The threshold values likely represent the discharges at which flow reverses on the channels and Athabasca River water begins to enter the lakes. 
High sediment water was detected in Lake 4 on just two days, neither of which corresponds to high discharge. This lake is likely disconnected from the river system by natural levees that are not overtopped even during high flow events. In Lakes 5 and 6, there is some suggestion of a threshold discharge value above which SAI is always greater than 0 , but the relationships for these lakes are complicated by the presence of many instances of high SAI and low river discharge. We know from field observations that Lakes 5 and 6 , like Lakes 1, 2, and 3, are hydrologically connected to the Athabasca River through distributary channels. The apparent discharge thresholds on Lakes 5 and 6 may represent inflow of river water. In these lakes, however, other factors that are not as influential in Lakes 1, 2, and 3, such as resuspension of lake-bottom sediments by wind, likely increase SAI without influence from the river.

The river discharge thresholds for inflow of water to the three high river-influence lakes are $1040 \mathrm{~m}^{3} / \mathrm{s}$ (Lake 1), $1150 \mathrm{~m}^{3} / \mathrm{s}$ (Lake 2), and $1850 \mathrm{~m}^{3} / \mathrm{s}$ (Lake 3). Previous studies have explored hydrologic connectivity in the PAD and have yielded qualitative measures of floodplain lake connectivity (e.g. Pavelsky \& Smith, 2008; Prowse \& Demuth, 1996; Wolfe et al., 2007), but no other study has previously identified discharge thresholds required for recharge. We use these thresholds to identify the number of days in each year since 1970 on which Athabasca River discharge is sufficiently high to recharge each lake (Figure 12). Because lake recharge often depends on relative water surface elevations in the river and lake, recharge likely did not occur on all days above this threshold, but a higher number of days above the discharge threshold likely implies greater overall recharge. Since 1970, there has been a statistically significant $(p<0.05)$ decrease in recharge frequency for each of the three lakes. During the first half of the study period (1970-1990), Lakes 1 and 2 were 
recharged in all years, and Lake 3 was recharged in every year except 1981 (Table 2). In contrast, during the second half of the study period (1991-2011) discharge on the Athabasca River failed to reach the threshold required to recharge Lake 2 three times, and the threshold for Lake 3 was met in just ten of the twenty years.

\section{Discussion and Conclusions}

The first principal conclusion of this study is that models for remotely sensing SSC developed in one location can, in some cases, be transferred to another location. The first criterion we identify for making such a transfer (i.e., that a near infrared band and a visible band used in combination are more effective than a single band used alone or another sort of combination) is supported by previous work also suggesting that multispectral models are preferable for remotely sensing SSC (e.g. Holyer, 1978; Schiebe et al., 1992; Topliss et al., 1990). Some previous studies (e.g. Doxaran et al., 2002; Holyer, 1978; Novo et al., 1989) have more specifically suggested that the best models use a combination of a near infrared and a red band. In our study, the model that produces the best linear correlation with our field dataset uses this combination, but five of the top seven models use a near infrared band paired with a green or blue band. This suggests that bands in the green and blue part of the spectrum may be just as effective as red bands for remotely sensing SSC as long as they are paired with a near infrared band.

Our results suggest that models developed using comparatively low SSCs have limited success predicting the higher SSCs in the PAD, while models based on higher SSCs are more effective. This finding is corroborated by past studies, which have found that different models are optimal for low and high SSCs (e.g. Ritchie et al., 2003) or that models 
which work well at low concentrations can saturate at higher concentrations (e.g. Ritchie and Cooper, 1988; Ritchie et al., 2003; Chu et al., 2009; Topliss et al., 1990; Holyer et al., 1978; Han and Rundquist, 1994). Some of the models we test are also predictive for low SSCs but then become saturated at higher concentrations (e.g. Doxaran et al., 2003; Topliss et al., 1990; Song et al., 2011) (Figure 7 d,e). Holyer et al., (1978) found that saturation occurs when using reflectance in the red band, but using a near infrared band along with a red band corrects this problem. In contrast, our analysis shows no discernible pattern in which spectral bands were used among models that saturate. We suggest instead that the gap between the maximum SSC from which these models were developed and the much higher SSCs we observe in the PAD may result in saturation at high SSCs.

Finally, we suggest that nonlinear models may be more successful for predicting SSCs in a new location than other forms. Past studies suggest that linear relationships are effective for remotely sensing SSCs less than $50 \mathrm{mg} / \mathrm{L}$, but for values greater than this, curvilinear relationships are necessary (Ritchie et al., 2003). In the PAD, we found that exponential relationships worked the best. This is likely because of the large range of SSCs in the PAD, and for different environments other nonlinear forms may also work well. In environments where SSCs are relatively low, the form of the relationship may not be as significant when selecting a model; Ritchie \& Zimba, 2006) noted that for SSCs between 0 and $50 \mathrm{mg} / \mathrm{L}$, reflectance from almost any visible or near-infrared wavelength is linearly related to SSC. Nevertheless, in the PAD, where SSCs range from less than 5 to more than $3000 \mathrm{mg} / \mathrm{L}$, equation form is an important factor influencing success of models in predicting SSCs and it should be considered when evaluating models for spatial transferability. 
If the three primary conditions identified here are not met, then application of an SSC-reflectance relationship beyond its area of development may produce unreliable results. Even when these requirements are met, it remains necessary to develop a constant correction coefficient, obtained from a linear regression between observed and modeled SSCs, to account for location-specific differences in factors like sediment color and grain size. If limited availability of in situ data prevents development of such a correction, it remains possible to accurately observe relative differences in SSC. For much of our work focusing on spatial and temporal patterns of SSC, relative SSC measurements would be fully adequate.

The scaled equation from Doxaran et al., (2009) which we use to map SSC in Lake Athabasca is substantially more sophisticated than prior models used in the PAD (Pavelsky \& Smith, 2009), and it fully addresses anomalously high predicted SSCs from that work associated with biological activity. Our results allow us to distinguish between sedimentladen river water input from the Peace and Athabasca Rivers for major flux events. Input of Peace River water to Lake Athabasca is not directly controlled by discharge from the river, depending instead on the relative water levels of the river and the lake (PAD-PG, 1973). If the lake level is lower than the river level, the Peace River will flow into the lake regardless of river discharge. Though it is not possible to predict the input of Peace River water to Lake Athabasca using river discharge alone, remote monitoring of SSC allows us to track occurrences of inflow in the absence of in situ monitoring.

In contrast to the Peace River, the Athabasca River always flows into Lake Athabasca, and we expect to observe a relationship between discharge and input of river water to the lake. However, discharge and SSC in the lake are not significantly correlated for 
discharge less than $\sim 1700 \mathrm{~m}^{3} / \mathrm{s}$ and SSC less than $\sim 100 \mathrm{mg} / \mathrm{L}$, which suggests that river discharge is not the only important control on SSC in Lake Athabasca. Wind almost certainly also influences SSC at the water surface through resuspension of bottom sediment and mixing of lake and river water, and at low discharges it may overwhelm the river signal. It is also possible that when discharge is less than $1700 \mathrm{~m}^{3} / \mathrm{s}$, sediment settles out of suspension within the river itself before reaching the lake. At high discharge values, however, input of high sediment water appears to overcome these confounding factors and SSC becomes more strongly related to discharge.

Even at the lowest discharges, Athabasca River water flows into Lake Athabasca, but this is not always the case in the small floodplain lakes in the PAD. We assess the connectivity of six of these floodplain lakes to gain a more thorough understanding of recharge in the delta. Prowse and Demuth (1996) examined hydrologic connectivity in the PAD and divided the delta into regions of "open," "restricted," and "isolated" drainage based on the work of Jaques, and PAD-PG (1973). Based on these classifications, our high riverinfluence and strongly connected lakes (Lakes 1-3) as well as two of our low river-influence lakes (4 and 6) are in "restricted" zones. Lake 5, which we found to be more connected to the river than Lake 4, is in an "isolated" zone. Wolfe et al. (2007) use the same three classifications as Prowse and Demuth (1996) and also include a fourth category for very shallow, rainfall-influenced lakes. They base their classifications on $\delta^{18} \mathrm{O}$-derived evaporation-to-inflow ratios and examine three of our six study lakes: Lakes 2 and 3 are defined as "open," and Lake 5 is defined as "restricted." Our results agree more closely with the classifications of Wolfe et al. (2007) than with those of Prowse and Demuth (1996). Compared to these previous methods for observing hydrologic connectivity in the PAD, the 
principal advantage of the method used here is that it allows us to identify specific occurrences of lake recharge and thus determine discharge thresholds on the Athabasca River associated with lake recharge.

The three lakes most proximal to Lake Athabasca are the low river influence lakes, and it is likely that the lake level in Lake Athabasca strongly influences the amount of water and sediment they receive, especially when lake levels are high (Pavelsky \& Smith, 2008; Peters et al., 2006). The low river influence lakes are also significantly shallower than the high river influence (Smith \& Pavelsky, 2009) and sediment re-suspension due to wind likely interferes with the river discharge signal. Bottom-reflectance may also impact remote measurement of SSCs in these shallow lakes. Our results are in accordance with the findings of Pavelsky and Smith (2009), who found that suspended sediment in Lake 5 did not closely mirror discharge in the summer months, as well as with Prowse and Demuth (1996), whose classification shows Lake 5 as an "isolated" basin that is significantly recharged only by overbank flooding. Pavelsky and Smith (2008) noted that Lake 5 was hydrologically connected to the river system in 2007; our observation of an apparent threshold is in accordance with this finding, since in 2007 Athabasca River discharge exceeded the apparent threshold required to recharge Lake 5.

The identification of threshold discharges required to recharge lakes that are strongly influenced by the Athabasca River is valuable for understanding the effects on the PAD of declines in flow on the Athabasca River. In the past four decades, we have observed a substantial decline in the number of days on which Athabasca River discharge is sufficiently high to recharge the floodplain lakes studied here. In particular, recharge from the Athabasca River to Lake 3 has changed from occurring annually to occurring irregularly. Our results 
also suggest that if summer discharge on the Athabasca River continues to decline at the current rate, many small floodplain lakes (e.g. Lakes 1-3 in our analysis) will no longer be recharged with Athabasca River water except during the spring ice-jam flood period by approximately the 2040s, and possible as early as the 2020s in the case of Lake 3. Transformation of the Athabasca portion of the PAD from a frequently to an infrequently flooded environment has the potential to substantially affect delta ecology and biological productivity (McGowan et al., 2011; Prowse \& Conly, 2002; Wiklund et al., 2011). A reduction in the frequency of recharge would allow willow (Salix sp.) and shrub communities to overtake more productive grass- and sedge- dominated environments that currently serve as habitats for migratory birds (Timoney, 2006; Töyrä \& Pietroniro, 2005). Those lakes identified as highly river-influenced (i.e. Lakes 1, 2, and 3) are likely to face the most changes in their ecology and productivity, and all of these effects could be amplified by continued climate change or increased water withdrawals on the Athabasca River for use in the Alberta Oil Sands development (Schindler and Donahue, 2006). 
Figures

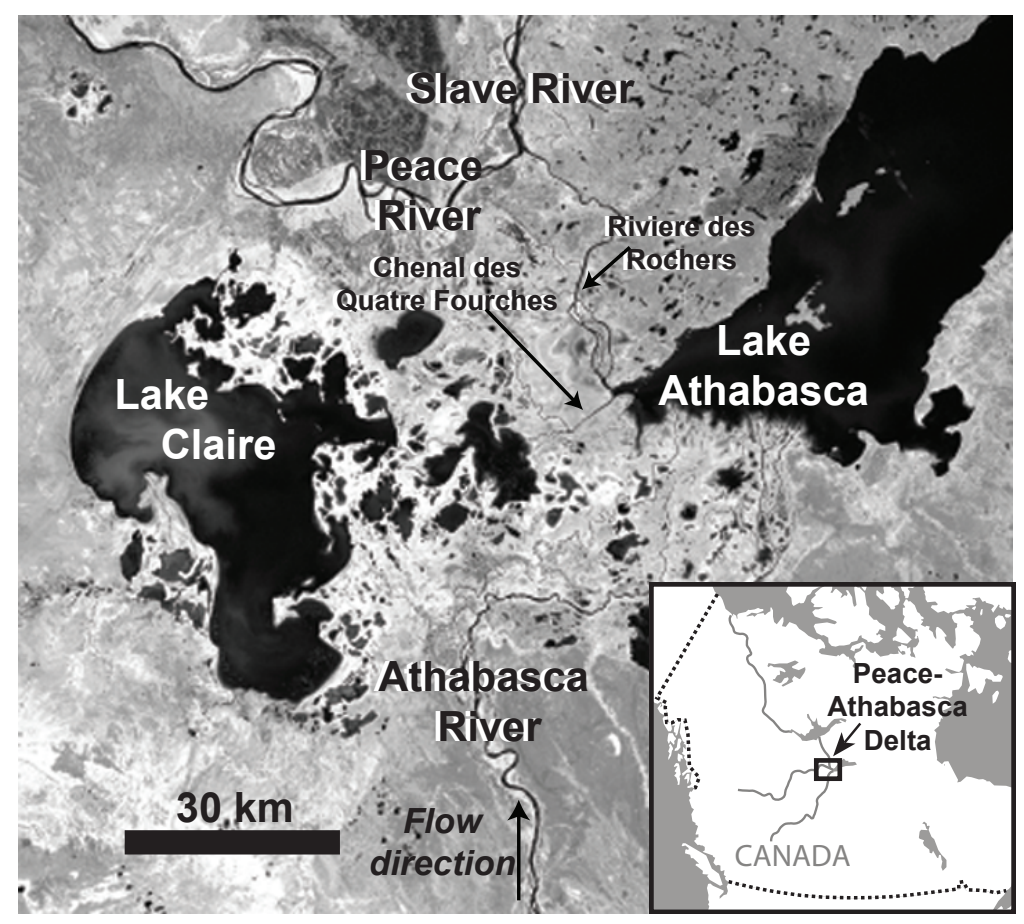

Figure 1. Landsat image of the Peace-Athabasca Delta. Inset (from Pavelsky and Smith, 2009) shows location of the delta in Canada.

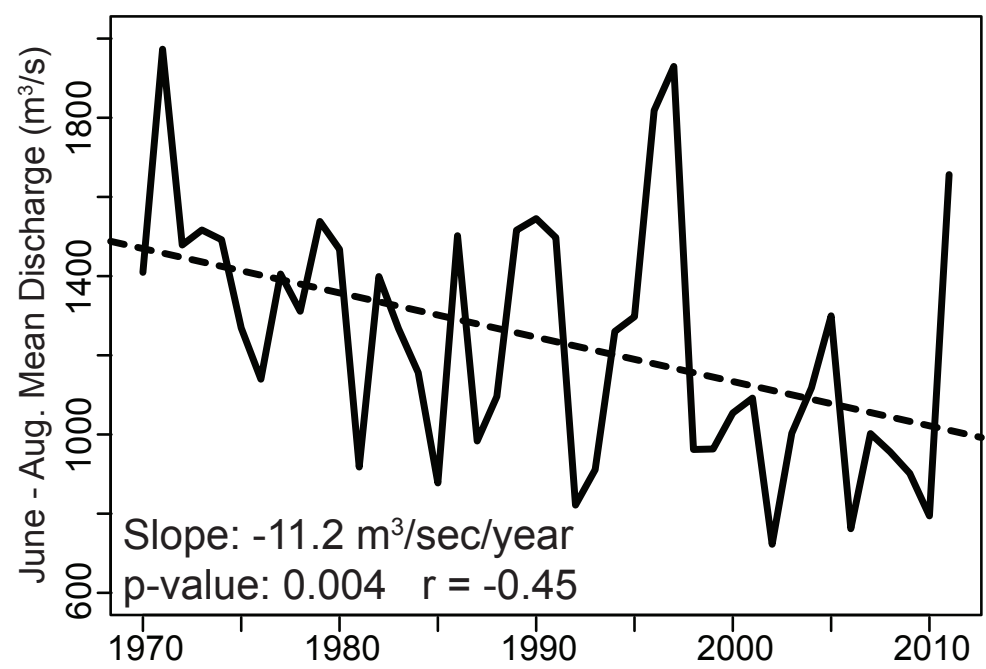

Figure 2. Mean summer (June-July-August) discharge on the Athabasca River below Fort McMurray from 1970-2011. Dashed line shows statistically significant decline in discharge over the time period. 


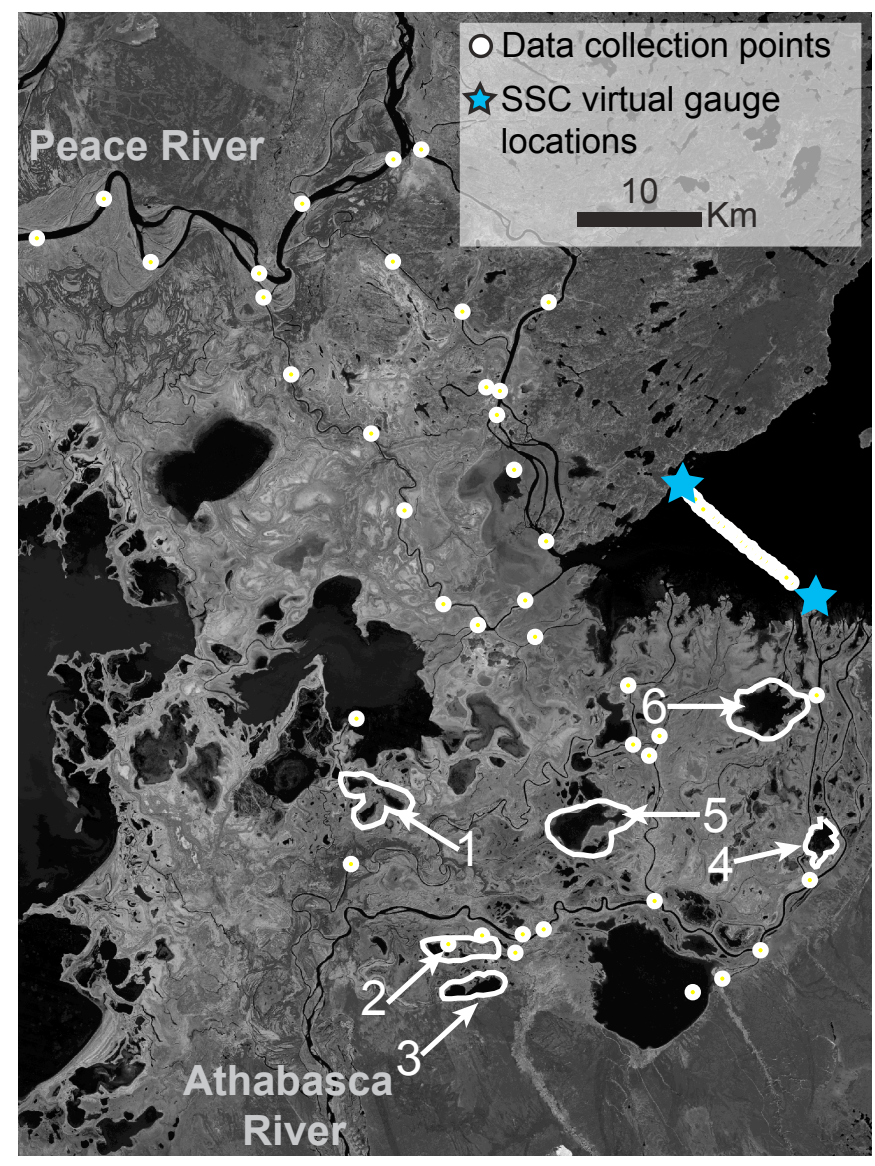

Figure 3. Landsat image of the central PAD showing the 71 locations where field data was collected in 2011. Outlined are the six small lakes referenced in Figures 11 and 12. Stars mark the locations of the virtual SSC gauges where the values in Figure 9 were calculated. 
a.

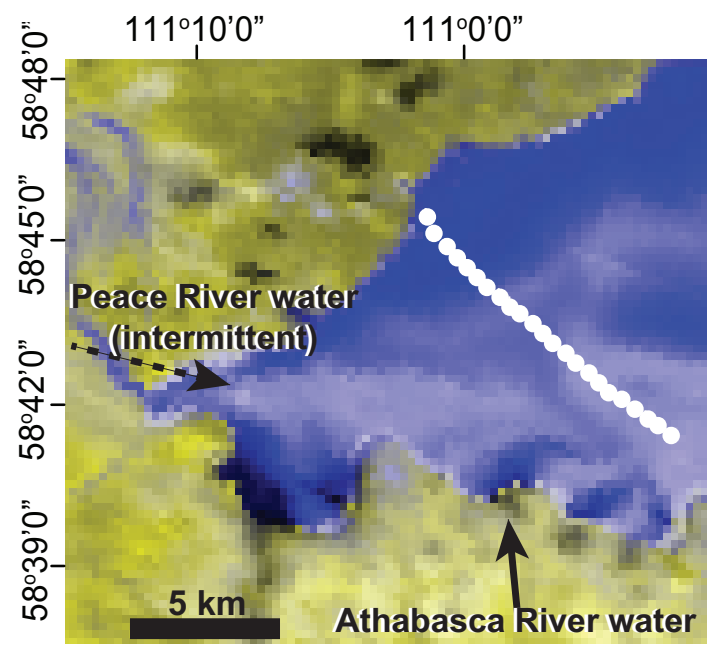

b.

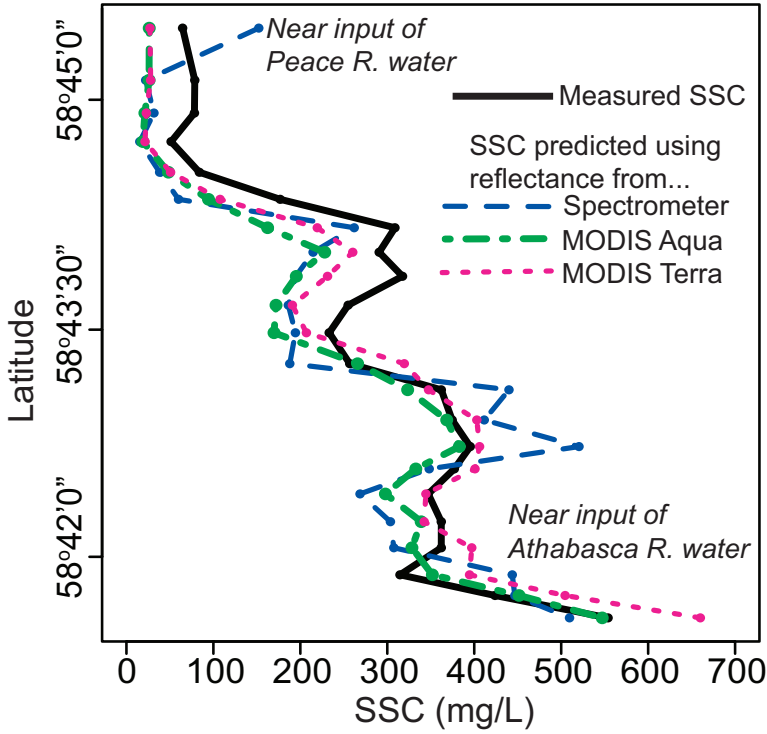

Figure 4. (a) False color MODIS image from the Terra platform obtained on June 27, 2011. Transect of 23 points where field measurements of SSC and reflectance were collected are shown in white. (b) Comparison between measured SSCs and those predicted using sameday reflectance from the spectrometer, MODIS Terra, and MODIS Aqua as inputs to the model from Doxaran et al., (2009) scaled for the PAD.

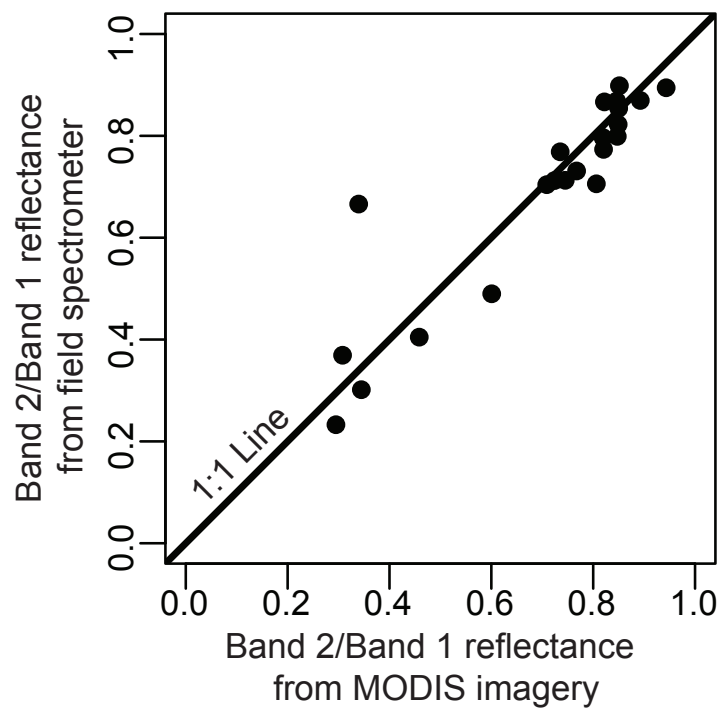

Figure 5. Comparison between the Band 2/Band 1 reflectance ratio from MODIS imagery and from field spectrometer measurements. Close fit to a 1:1 line verifies transferability of models between reflectance data sets. 


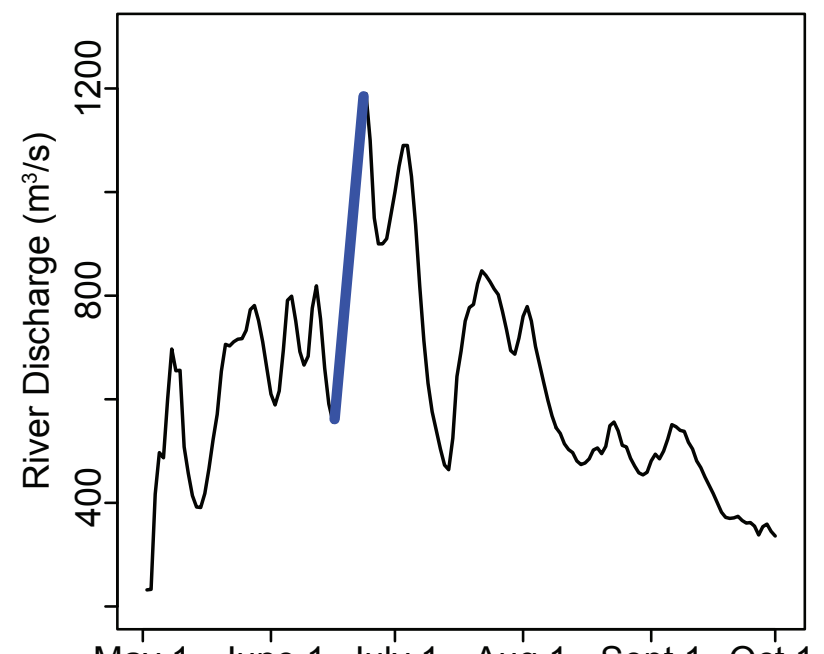

\begin{tabular}{|c|c|c|}
\hline Year & $\begin{array}{c}\text { Beginning } \\
\text { day of high } \\
\text { discharge } \\
\text { event }\end{array}$ & $\begin{array}{c}\text { Day of discharge } \\
\text { maximum for } \\
\text { selected event }\end{array}$ \\
\hline 2000 & June 8 & June 16 \\
\hline 2001 & July 19 & July 29 \\
\hline 2002 & June 16 & June 24 \\
\hline 2003 & June 22 & June 26 \\
\hline 2004 & July 6 & July 14 \\
\hline 2005 & July 21 & July 29 \\
\hline 2006 & July 28 & August 5 \\
\hline 2007 & June 5 & June 11 \\
\hline 2008 & August 11 & August 16 \\
\hline 2009 & July 11 & July 14 \\
\hline 2010 & July 13 & July 20 \\
\hline 2011 & June 18 & June 24 \\
\hline
\end{tabular}

Figure 6. River discharge on the Athabasca River below Ft. McMurray in 2002 as an example to show metric used for analyses. Bold, highlighted portion indicates the rising limb of the first summertime (after June 1) hydrograph peak (defined as an increase of $>60 \%$ between inflection points). Table shows timing and duration of all such events for 20002011. 

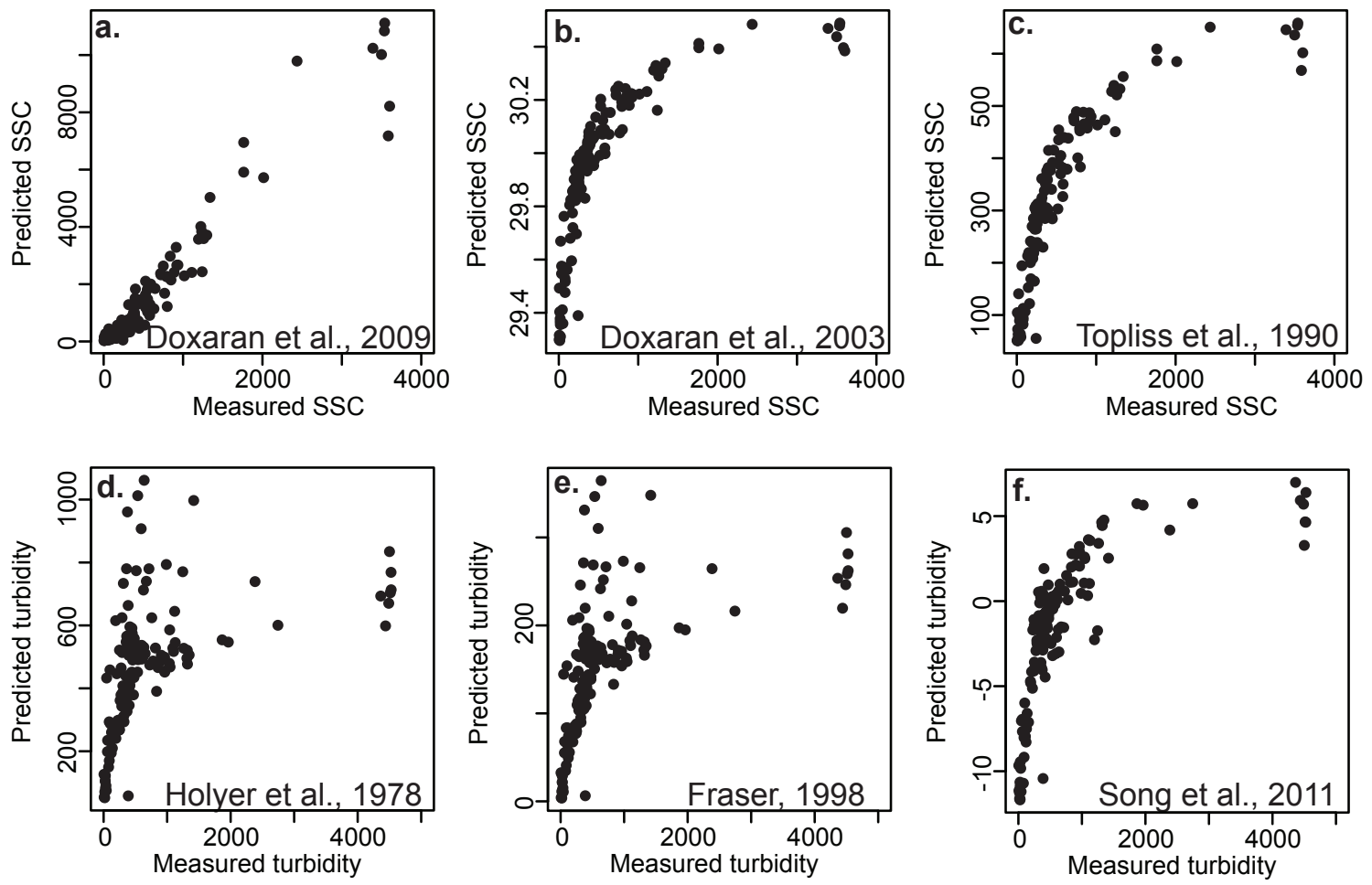

Figure 7. Subset of the 31 SSC-reflectance models used to model SSC data in the PAD. Plots show the relationship between measured values for SSC $(\mathrm{mg} / \mathrm{L})(\mathrm{a}-\mathrm{c})$ or turbidity (NTU) (d-f) on the $\mathrm{x}$-axis and predicted values on the $\mathrm{y}$-axis. See Table 1 for complete equations and Spearman's $\rho$ values. 

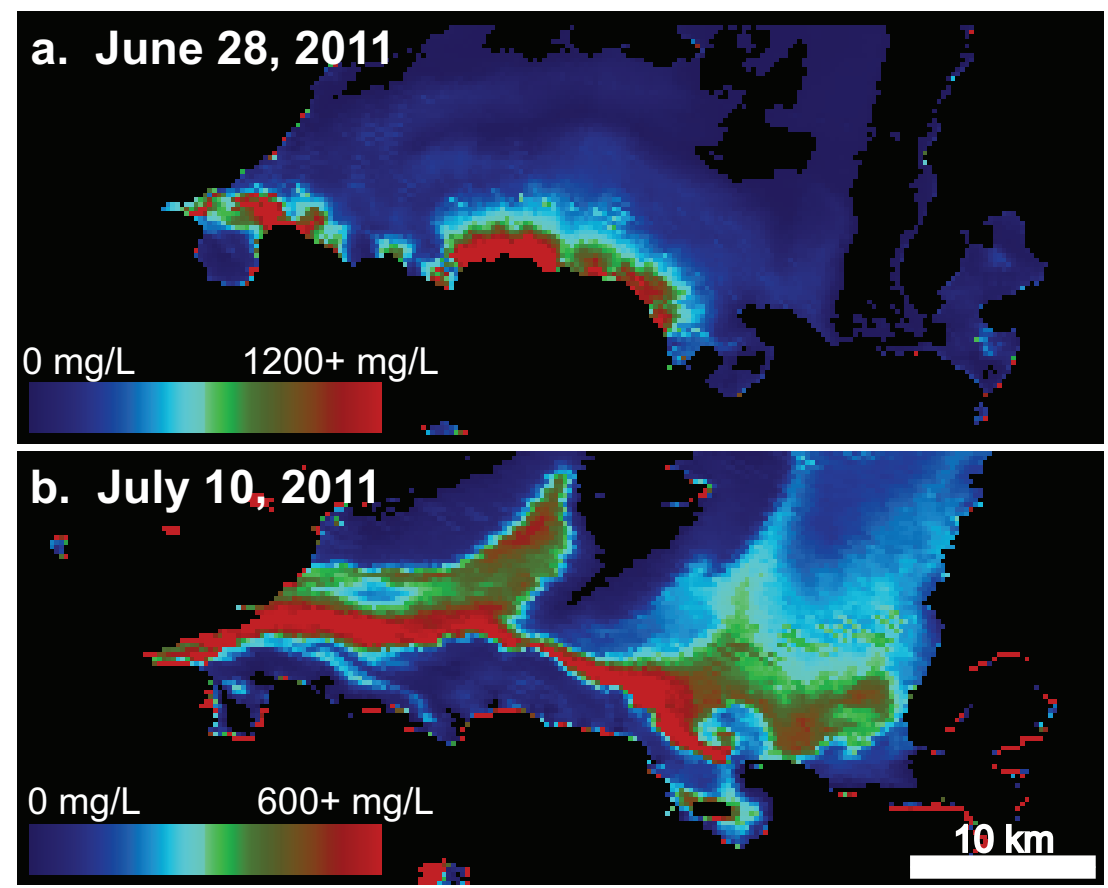

Figure 8. MODIS-derived sediment maps of the westernmost end of Lake Athabasca on (a) a day when only the Athabasca River is flowing into the lake and (b) a day when the Peace River is delivering high sediment water to the lake. 

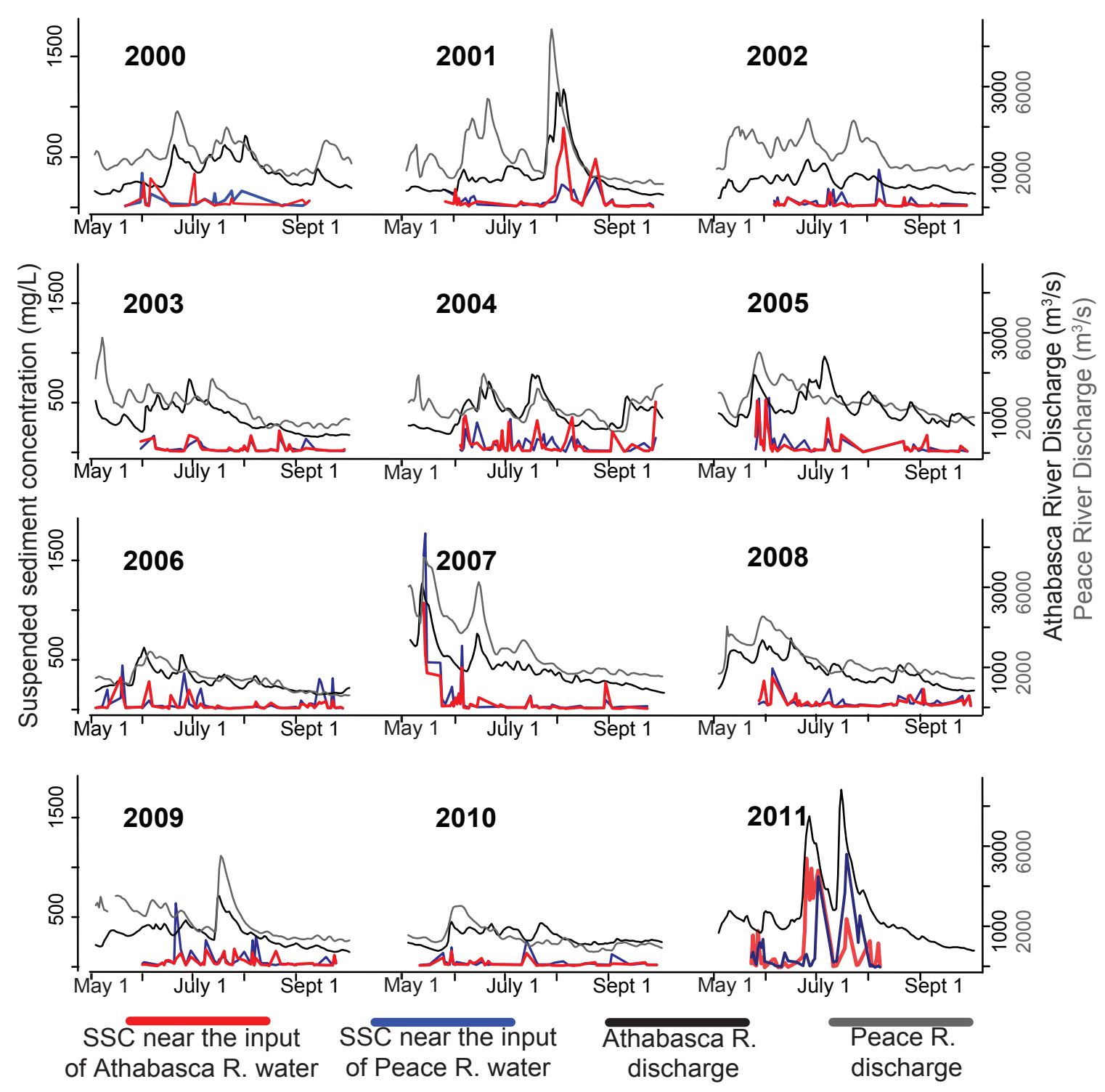

Figure 9. Annual time series of SSC in the western end of Lake Athabasca and discharge on the Peace and Athabasca Rivers. 


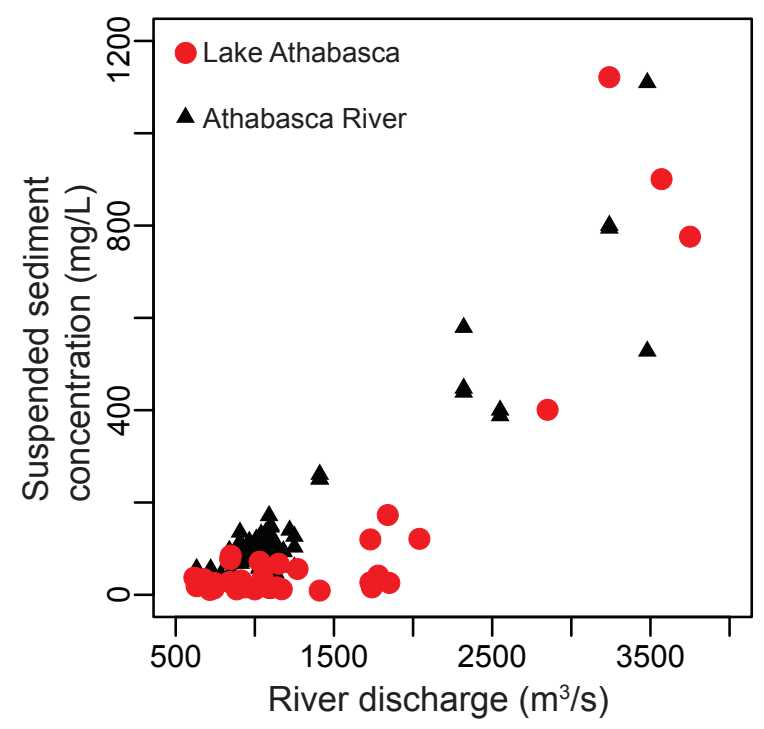

Figure 10. Athabasca River discharge vs. MODIS-derived SSC in Lake Athabasca near the margin of the Athabasca Delta (red points). Athabasca River discharge vs. in situ measurements of SSC in the river (black triangles). 

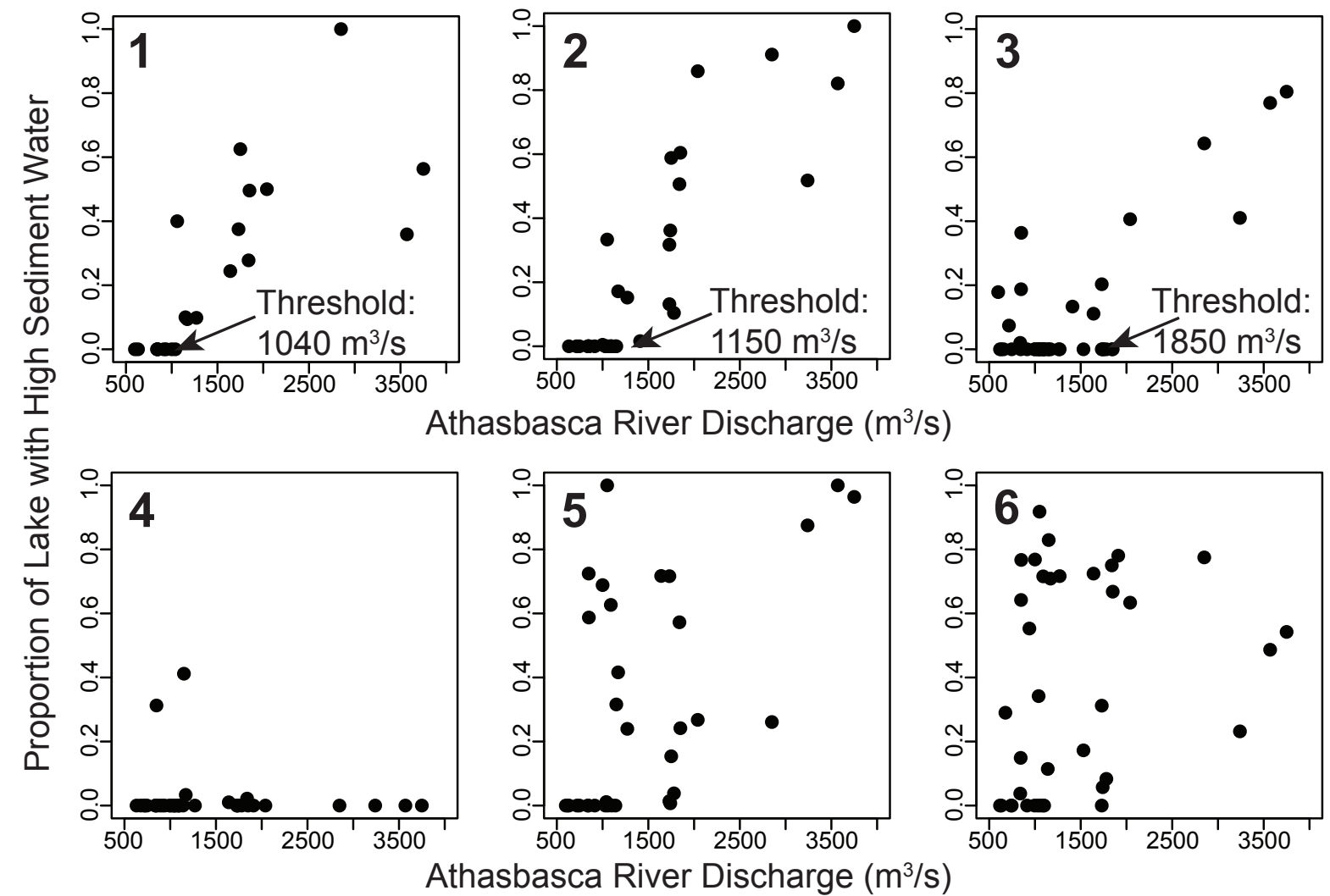

Figure 11. Plots of Athabasca River discharge vs. Sediment Area Index, or proportion of lake water that is classified as "high sediment," for six small lakes in the Athabasca Delta. Lake numbers correspond to labels in Figure 3. River discharge thresholds required to recharge Lakes 1, 2, and 3 with river water are labeled. 


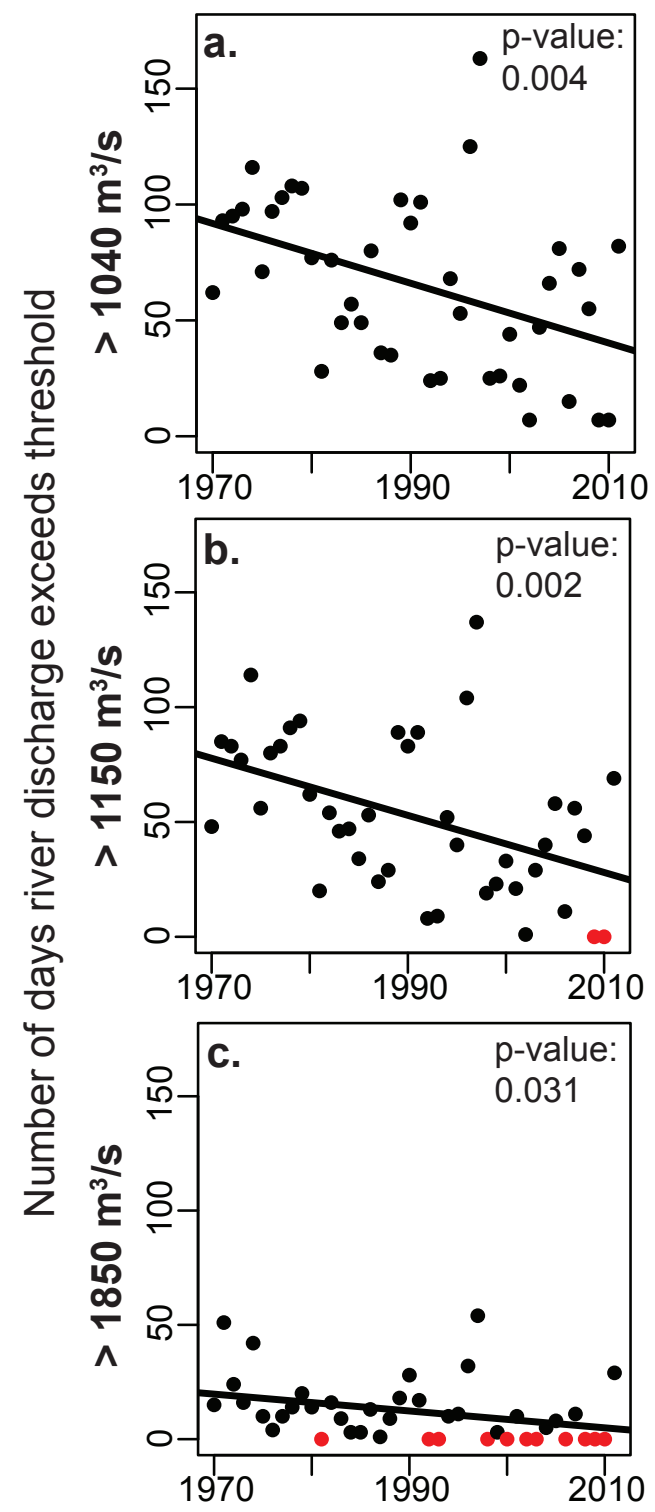

Figure 12. Number of days (y-axis) when Athabasca River discharge is above a threshold in each year (x-axis) from 1970-2011. Thresholds are (a) $1040 \mathrm{~m}^{3} / \mathrm{s}$, (b) $1150 \mathrm{~m}^{3} / \mathrm{s}$, and (c) $1850 \mathrm{~m}^{3} / \mathrm{s}$ and are for Lakes 1, 2, and 3, respectively. Decreases in the frequency of threshold exceedence are statistically significant $(\mathrm{p}<0.05)$ in all cases. 
Tables

\begin{tabular}{|c|c|c|c|c|c|}
\hline $\begin{array}{l}\text { Data } \\
\text { Products/ } \\
\text { Bands }\end{array}$ & Wavelengths & $\begin{array}{l}\text { Empirical Relationship between suspended sediment } \\
\text { (or turbidity) and reflectance }\end{array}$ & $\begin{array}{c}\text { Max } \\
\text { SSC } \\
\text { (mg/L) } \\
\text { or } \\
\text { Turbidity } \\
\text { (NTU) }\end{array}$ & $\begin{array}{l}\text { Spear- } \\
\text { man's } \\
\rho\end{array}$ & Reference \\
\hline $\begin{array}{l}\text { Landsat TM } \\
2 \text { and } 4\end{array}$ & $\begin{array}{l}\mathrm{R} 1=520-600 \\
\mathrm{R} 2=760-900\end{array}$ & $S P M=29.022 \times e^{0.0335 *\left(\frac{R 2}{R 1}\right)}$ & $\sim 2500$ & 0.97 & $\begin{array}{l}\text { Doxaran et al., } \\
2003\end{array}$ \\
\hline Sea WiFS & $\begin{array}{l}\mathrm{R} 1=545-565 \\
\mathrm{R} 2=845-885\end{array}$ & $S P M=26.083 \times e^{0.0366\left(\frac{R 2}{R 1}\right)}$ & $\sim 2500$ & 0.96 & $\begin{array}{l}\text { Doxaran et al., } \\
2003\end{array}$ \\
\hline $\begin{array}{l}\text { SPOT XS3 } \\
\text { and XS1 }\end{array}$ & $\begin{array}{l}\mathrm{R} 1=510-590 \\
\mathrm{R} 2=790-890\end{array}$ & $S P M=18.895 \times e^{0.0322 \times\left(\frac{R 2}{R 1}\right)}$ & $\sim 2500$ & -0.96 & $\begin{array}{l}\text { Doxaran et al., } \\
2003\end{array}$ \\
\hline $\begin{array}{l}\text { SPOT XS3 } \\
\text { and XS1 }\end{array}$ & $\begin{array}{l}\mathrm{R} 1=510-590 \\
\mathrm{R} 2=790-890\end{array}$ & $S P M=27.424 \times e^{0.0279 \times\left(\frac{R 2}{R 1}\right)}$ & $\sim 2500$ & -0.96 & $\begin{array}{l}\text { Doxaran et al.. } \\
2003\end{array}$ \\
\hline $\begin{array}{l}\text { Landsat MSS } \\
5 \text { and } 6\end{array}$ & $\begin{array}{l}\mathrm{R} 1=600-700 \\
\mathrm{R} 2=700-800\end{array}$ & $\ln (S S C)=-6.2\left(\frac{R 1}{R 2}\right)+1.4\left(\frac{R 1}{R 2}\right)^{2}+10.8$ & 1000 & 0.96 & $\begin{array}{l}\text { Topliss et al., } \\
1990\end{array}$ \\
\hline $\begin{array}{l}\text { MODIS 1 } \\
\text { and } 2\end{array}$ & $\begin{array}{l}\mathrm{R} 1=620-670 \\
\mathrm{R} 2=841-876\end{array}$ & $S P M=12.996 * e^{\frac{R 2}{R 1} / 0.189}$ & $\sim 2250$ & 0.95 & $\begin{array}{l}\text { Doxaran et al., } \\
2009\end{array}$ \\
\hline $\begin{array}{l}\text { Landsat TM } \\
1,3,4\end{array}$ & $\begin{array}{l}R 1=450-520 \\
R 2=630-690 \\
R 3=760-900\end{array}$ & Turbidity $=11.31 * \frac{R 3}{R 1}-2.03 * R 2-16.4$ & $\sim 12$ & 0.87 & $\begin{array}{l}\text { Song et al., } \\
2011\end{array}$ \\
\hline $\begin{array}{l}\text { Landsat TM } \\
4\end{array}$ & 790-900 & Turbidity $=16.1 * R-12.7$ & $\sim 5$ & 0.76 & Fraser, 1998 \\
\hline MODIS 2 & $841-876$ & $\ln (S S C)=(43.233 * R)+1.396$ & 2500 & 0.75 & $\begin{array}{l}\text { Wang et al., } \\
2009\end{array}$ \\
\hline $\begin{array}{l}\text { Field } \\
\text { spectrometer }\end{array}$ & 782 & Turbidity $=\left(1181 \times R^{2}\right)+(4062 \times R)-0.0$ & $\sim 2.5$ & 0.72 & Holyer, 1978 \\
\hline $\begin{array}{l}\text { Field } \\
\text { spectrometer }\end{array}$ & $\begin{array}{l}\mathrm{R} 1=652 \\
\mathrm{R} 2=782\end{array}$ & $\begin{array}{l}\text { Turbidity }=\left(233.7 \times R^{2}\right)-\left(1384 \times R^{2}\right)+ \\
(1120 \times R)+(4853 \times R)-5.08\end{array}$ & 50 & 0.67 & Holyer, 1978 \\
\hline $\begin{array}{l}\text { CASI Channel } \\
11\end{array}$ & $\begin{array}{l}755.5-780.8 \\
\text { (rounded to } \\
755-781 \text { ) }\end{array}$ & $S S C=529 * R$ & 2000 & 0.65 & $\begin{array}{l}\text { Wass et al., } \\
1997\end{array}$ \\
\hline $\begin{array}{l}\text { AHS } \\
\text { Advanced } \\
\text { Hyperspectral } \\
\text { Sensor } \\
\end{array}$ & $\begin{array}{l}\mathrm{R} 1=819-847 \\
\mathrm{R} 2=989-1019\end{array}$ & $\ln (T S M)=34.18 *(R 1-R 2)+3.16$ & 336 & 0.60 & $\begin{array}{l}\text { Sterckx et al., } \\
2007\end{array}$ \\
\hline Sea WiFS & $\begin{array}{l}\mathrm{R} 1=660-680 \\
\mathrm{R} 2=545-565\end{array}$ & $S P M=17.783 *\left(\frac{R 1}{R 2}\right)^{1.11}$ & $\sim 20$ & 0.47 & D'Sa et al., 2007 \\
\hline IKONOS red & $632-698$ & Turbidity $=0.078 * R-8.7$ & $\sim 1$ & 0.44 & $\begin{array}{l}\text { Hellweger et al., } \\
2007\end{array}$ \\
\hline Landsat TM 3 & $630-690$ & Turbidity $=10.0 * R-24.8$ & $\sim 5$ & 0.43 & Fraser, 1998 \\
\hline Landsat TM 1 & $450-520$ & Turbidity $=19.0 * R-97.9$ & $\sim 5$ & 0.43 & Fraser, 1998 \\
\hline $\begin{array}{l}\text { Field } \\
\text { spectrometer }\end{array}$ & 652 & Turbidity $=\left(33.96 \times R^{2}\right)+(5352 \times R)-4.38$ & $\sim 2.5$ & 0.42 & Holyer , 1978 \\
\hline MODIS 1 & $620-670$ & Turbidity $=1203.9 * R^{1.087}$ & $\sim 1$ & 0.43 & $\begin{array}{l}\text { Chen et al., } \\
2007\end{array}$ \\
\hline
\end{tabular}




\begin{tabular}{|c|c|c|c|c|c|}
\hline Landsat TM 2 & $520-600$ & Turbidity $=6.4 * R-28.0$ & $\sim 5$ & 0.39 & Fraser, 1998 \\
\hline CMODIS & $\begin{array}{l}\mathrm{R} 1=540-560 \\
\mathrm{R} 2=660-680\end{array}$ & $\log _{10} S=0.892+6.2244 *\left(\frac{R 1+R 2}{(R 1 / D ?)}\right)$ & $\sim 1000$ & 0.36 & Han et al., 2006 \\
\hline Landsat TM 3 & $630-690$ & $S S C=69.39 * R-201$ & 1150 & 0.36 & $\begin{array}{l}\text { Islam et al., } \\
2001\end{array}$ \\
\hline $\begin{array}{l}\text { Landsat MSS } \\
1 \text { and } 2\end{array}$ & $\begin{array}{l}\mathrm{R} 1=500-600 \\
\mathrm{R} 2=600-700\end{array}$ & $\ln (S S C)=-9.21\left(\frac{R 1}{R 2}\right)+2.71\left(\frac{R 1}{R 2}\right)^{2}+8.45$ & $\sim 150$ & 0.34 & $\begin{array}{l}\text { Ritchie \& } \\
\text { Cooper, } 1991\end{array}$ \\
\hline MOS/MESSR & $\begin{array}{l}\mathrm{R} 1=510-590 \\
\mathrm{R} 2=610-690\end{array}$ & $\ln (S S C)=-4.8\left(\frac{R 1}{R 2}\right)+0.9\left(\frac{R 1}{R 2}\right)^{2}+10.4$ & 1000 & 0.33 & $\begin{array}{l}\text { Topliss et al., } \\
1990\end{array}$ \\
\hline Landsat TM 3 & $630-690$ & $\log _{10}(S)=0.334+0.098 * R$ & 30 & 0.32 & $\begin{array}{l}\text { Keiner \& Yan, } \\
1998\end{array}$ \\
\hline $\begin{array}{l}\text { Landsat MSS } \\
5\end{array}$ & $600-700$ & $R=0.16+0.03 * \ln (S)$ & & 0.32 & $\begin{array}{l}\text { Aranuvachapun } \\
\text { \& Walling, } 1988\end{array}$ \\
\hline MODIS 1 & $620-670$ & $\ln (S S C)=50.171 * R-1.523$ & $\sim 2500$ & 0.31 & $\begin{array}{l}\text { Wang et al., } \\
2008\end{array}$ \\
\hline MODIS 1 & $620-670$ & $T S M=-1.91+1140.25 * R$ & 60 & 0.31 & $\begin{array}{l}\text { Miller \& } \\
\text { McKee, } 2004\end{array}$ \\
\hline MODIS 1 & $620-670$ & $R=7.5 * \log (S S C)+1.6$ & 500 & 0.31 & Chu et al., 2009 \\
\hline $\begin{array}{l}\text { Landsat TM } 2 \\
\text { and } 3\end{array}$ & $\begin{array}{l}\mathrm{R} 1=520-600 \\
\mathrm{R} 2=630-690\end{array}$ & $T S M=0.7581 * e^{61.683 *\left(\frac{R 1+R 2}{2}\right)}$ & 50 & 0.30 & $\begin{array}{l}\text { Dekker et al., } \\
2001\end{array}$ \\
\hline $\begin{array}{l}\text { Landsat TM } 1 \\
\text { and } 3\end{array}$ & $\begin{array}{l}\mathrm{R} 1=450-520 \\
\mathrm{R} 2=630-690 \\
\end{array}$ & $T S S=0.0167 * e^{12.3 \times \frac{R 2}{R 1}}$ & 35 & -0.05 & $\begin{array}{l}\text { Lathrop et al., } \\
1991\end{array}$ \\
\hline
\end{tabular}

Table 1. Compilation of published, empirically developed models relating suspended sediment concentration or turbidity to reflectance from the water surface. Maximum turbidity values have been converted to approximate SSCs. Equations are written as they are published, where SPM=Suspended Particulate Matter, SSC $=$ Suspended Sediment Concentration, TSM=Total Suspended Matter, SS=Suspended Solids, TSS=Total Suspended Solids. $R$ is the reflectance of the water at the given wavelengths. For equations that measure turbidity, maximum values shown in Column 5 have been converted to SSCs to facilitate intercomparison. Spearman's $\rho$ value is the correlation coefficient between SSC values measured in the PAD and SSC or turbidity values predicted by the model.

Scatterplots of observed vs. modeled values for the six bolded equations are shown in Figure 7.

\begin{tabular}{|c|c|c|c|}
\hline & Lake 1 & Lake 2 & Lake 3 \\
\cline { 2 - 4 } & $1040 \mathrm{~m}^{3} / \mathrm{s}$ & $1150 \mathrm{~m}^{3} / \mathrm{s}$ & $1850 \mathrm{~m}^{3} / \mathrm{s}$ \\
\hline $1970-1990$ & 0 & 0 & 1 \\
\hline $1991-2011$ & 0 & 3 & 10 \\
\hline
\end{tabular}

Table 2. Number of years in which threshold discharge required for lake recharge was not reached on the Athabasca River. 
Appendix 1: Water quality data and surface velocities

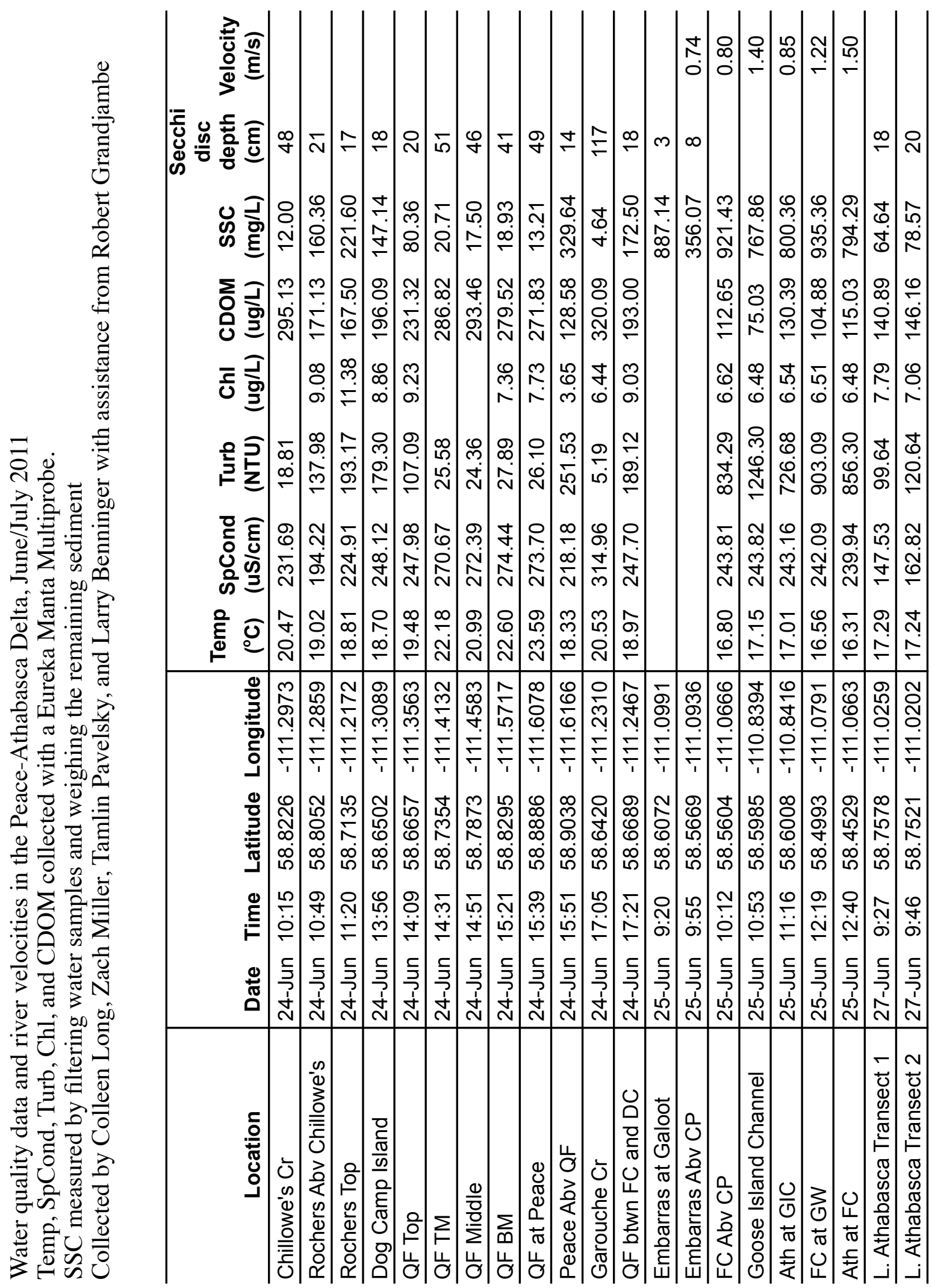




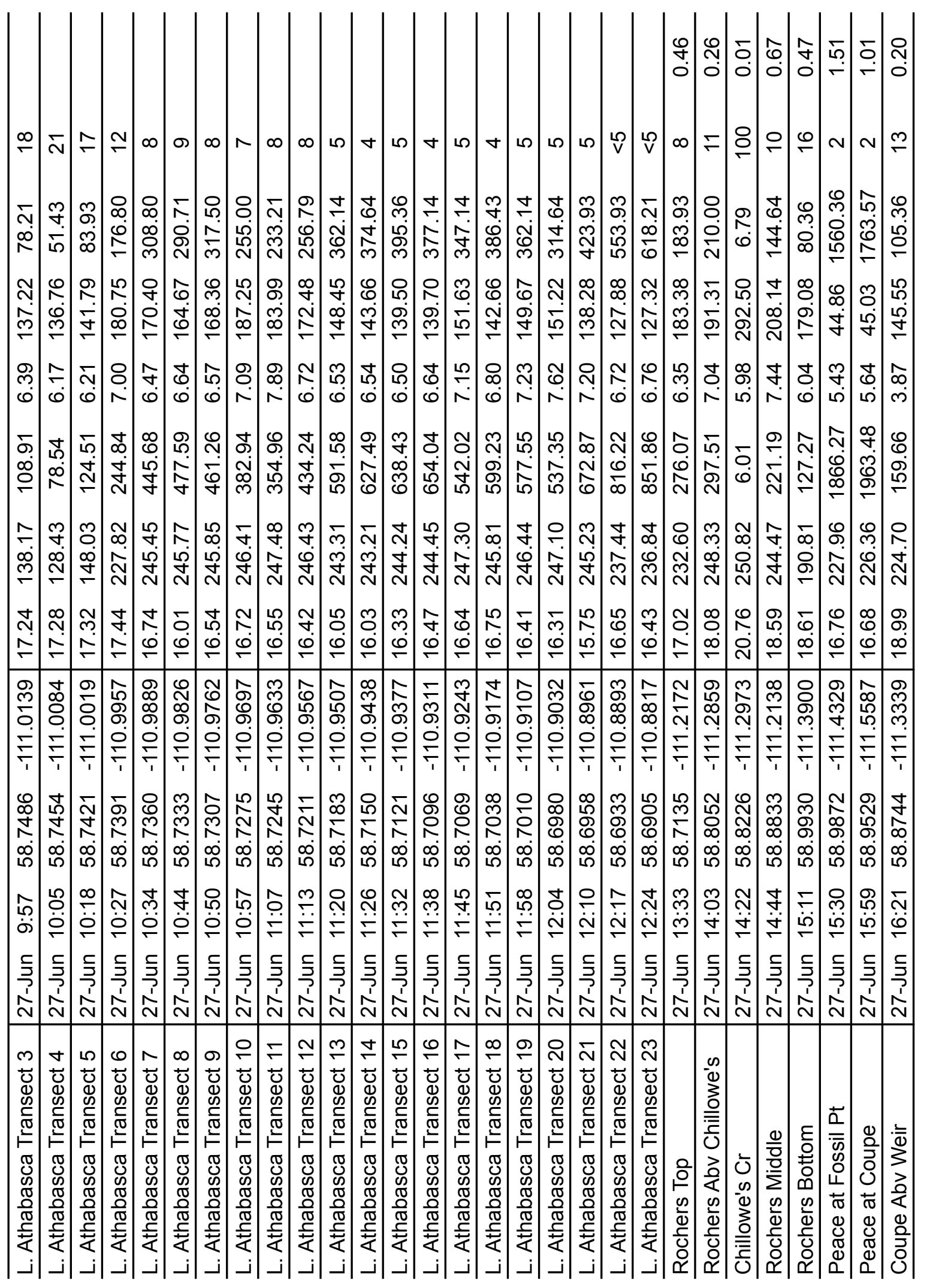




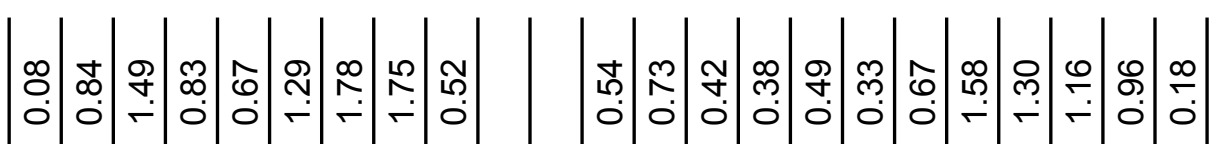

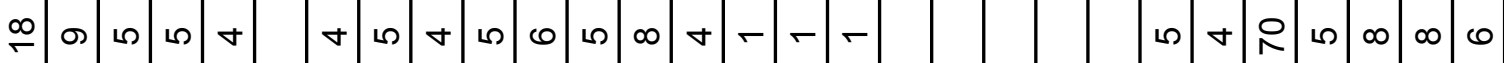

ঊ

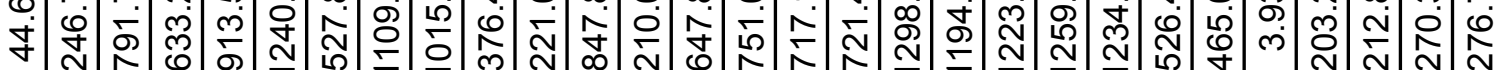

雨 సิ

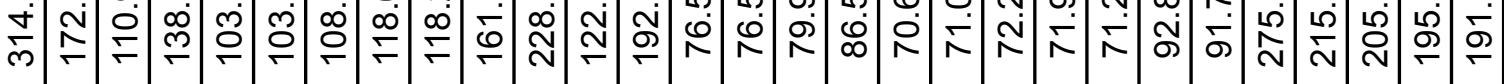

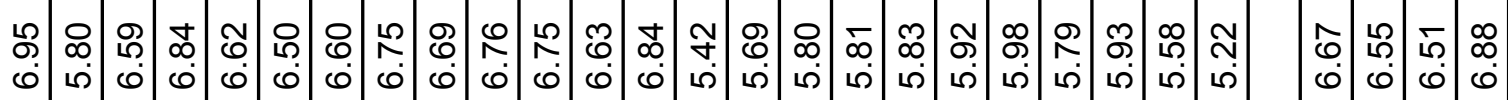
赵

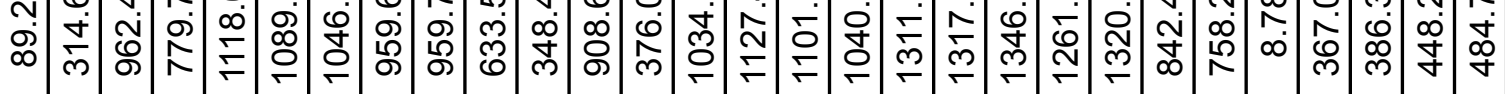

ำ ․

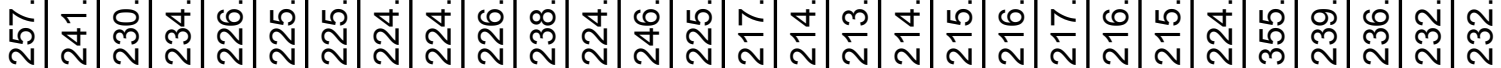
을 00 일

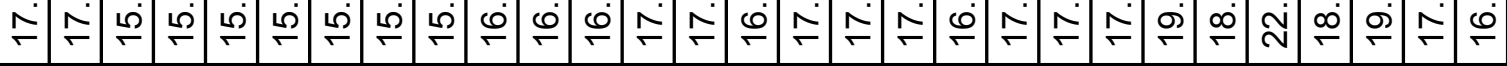
읏

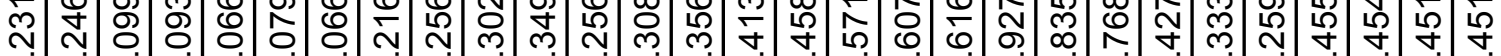

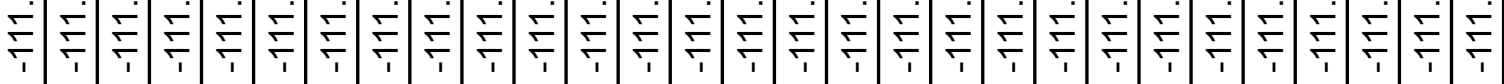

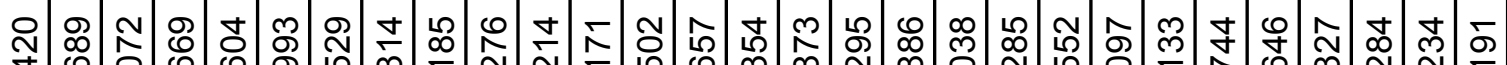

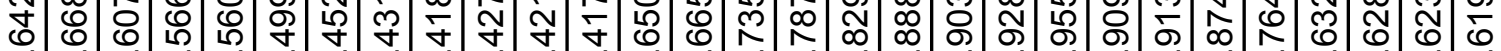

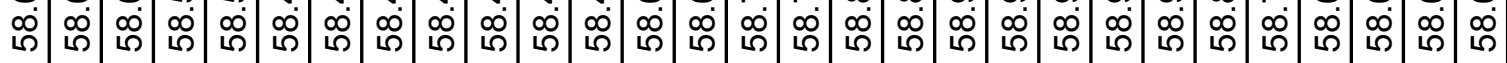

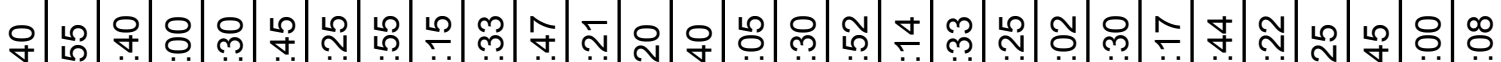
के 志

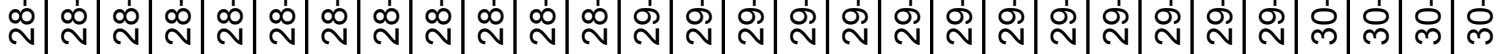

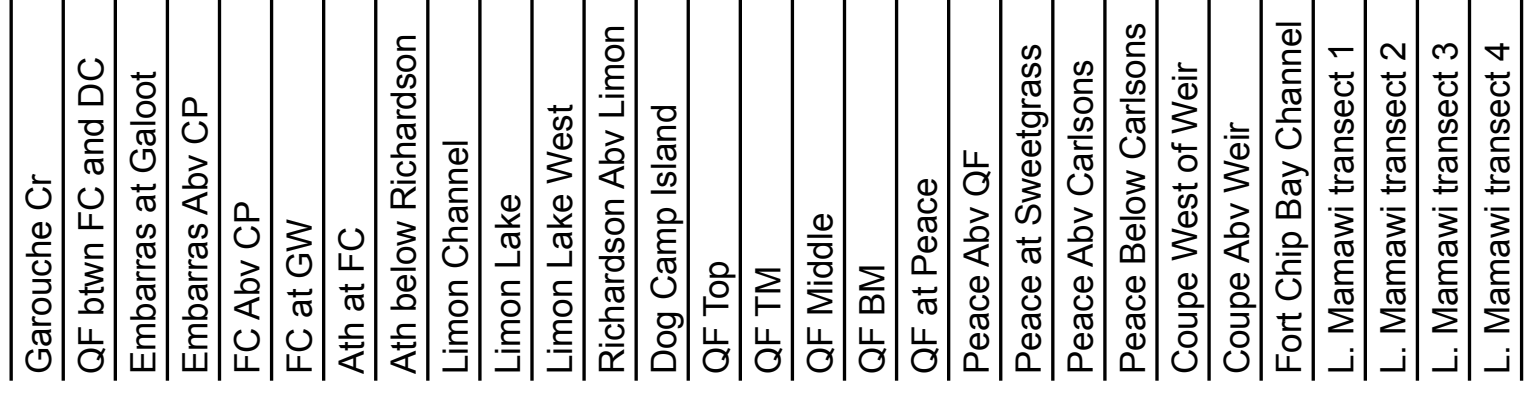




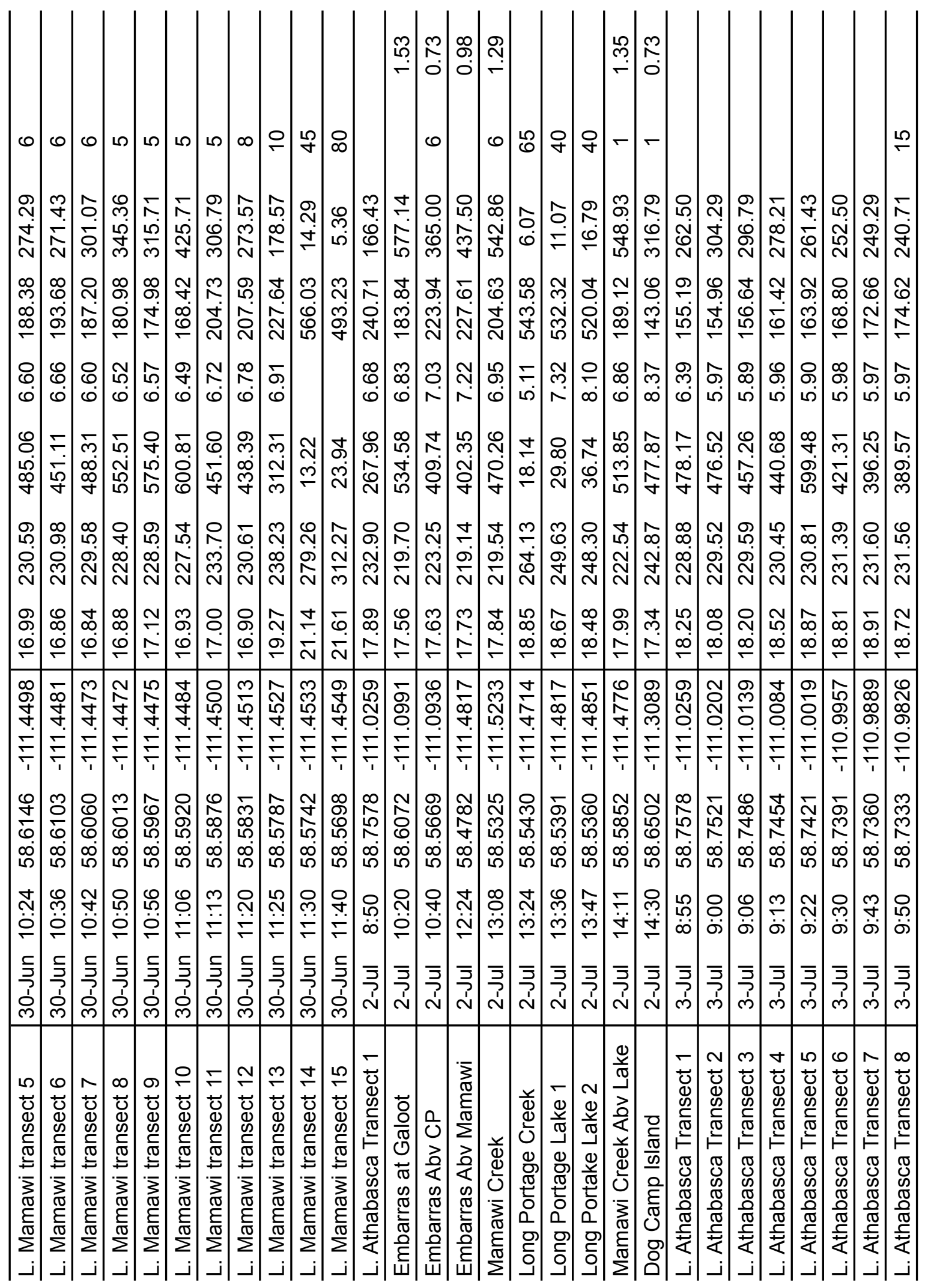




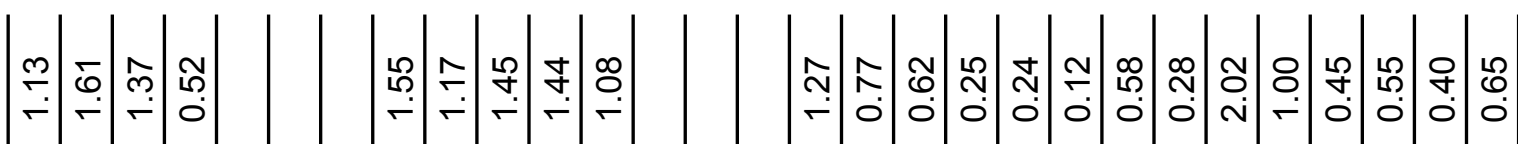
$\ln \div \frac{m}{2} \div$

र.

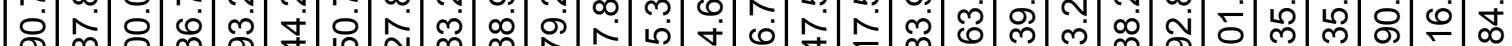

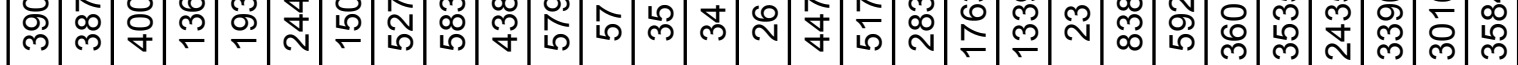
œ

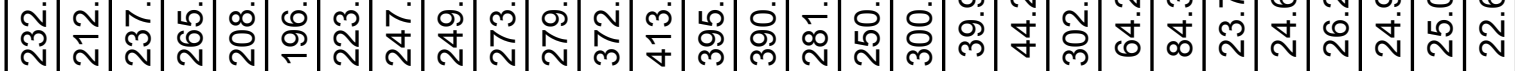

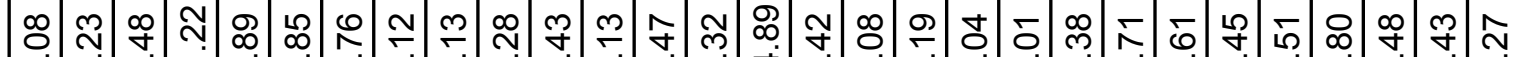

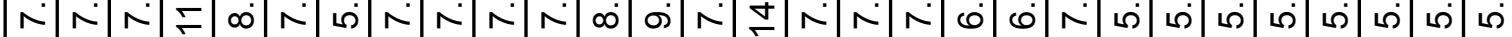

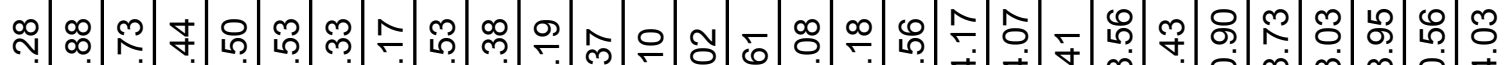
ம m

டி

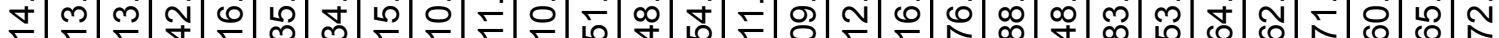

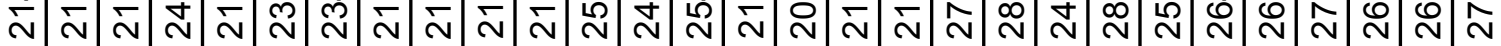
厶் ஜ ஜ ஜ

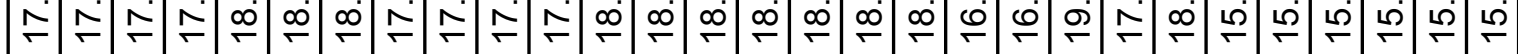

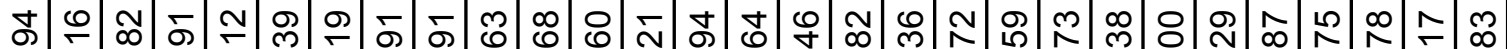

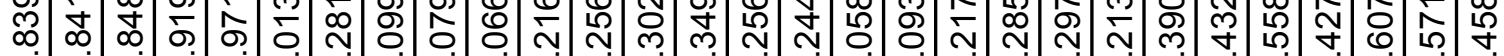

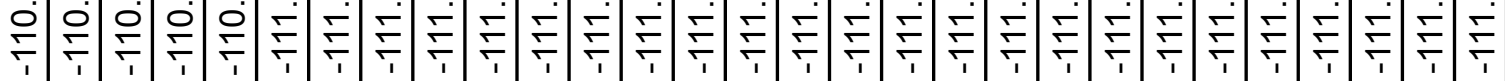

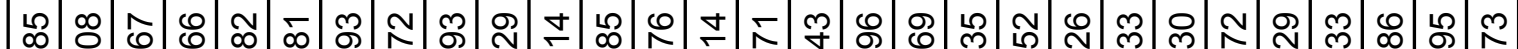

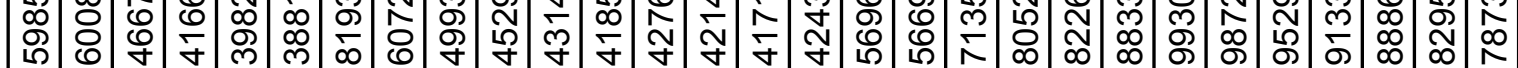

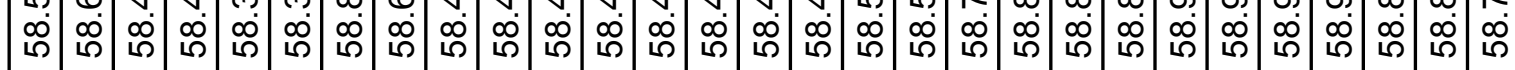
N

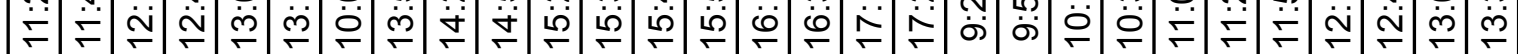

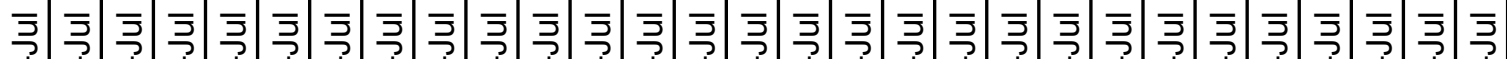

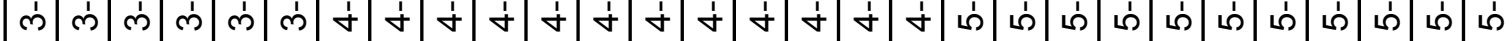

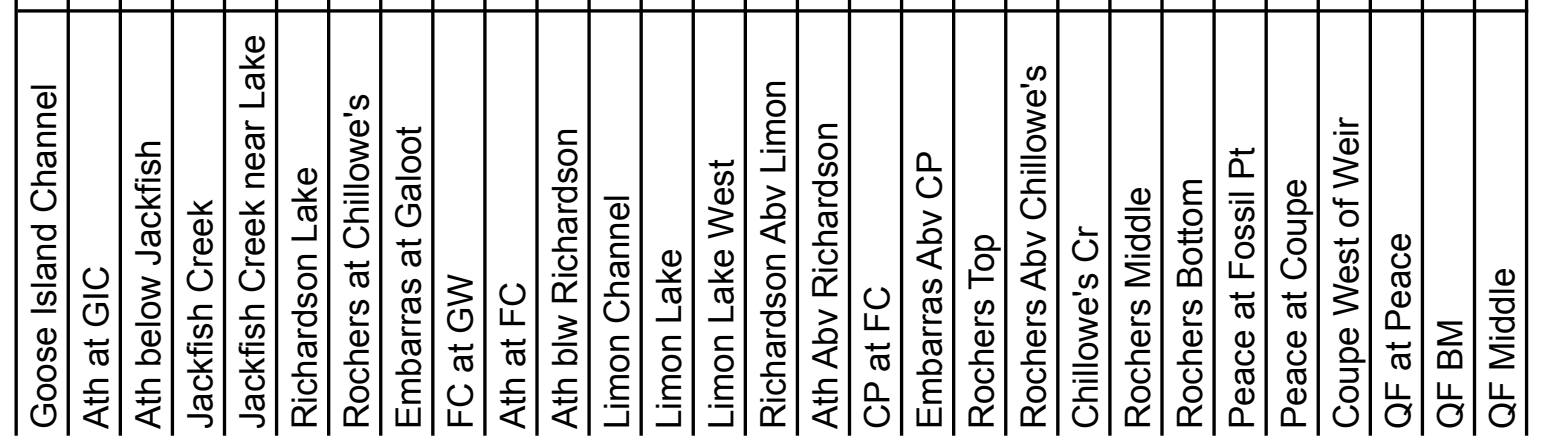




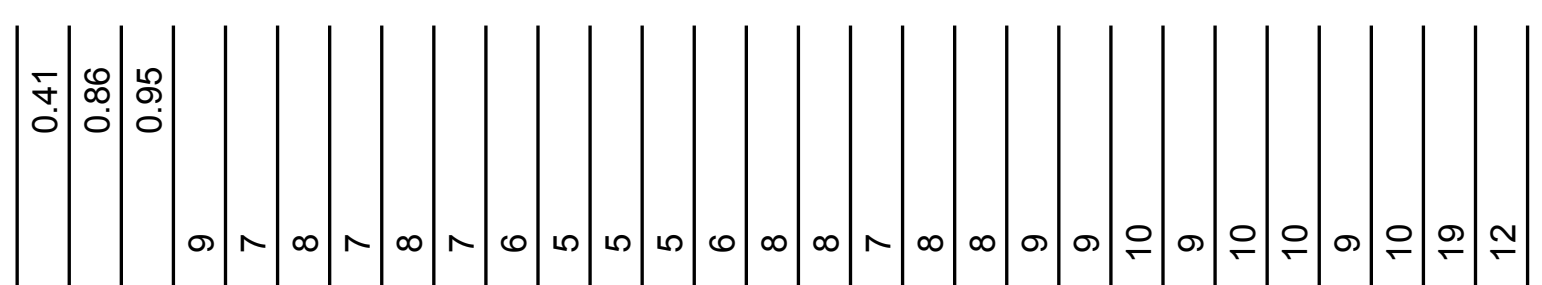

ని రీ 守穷 œ సं ○

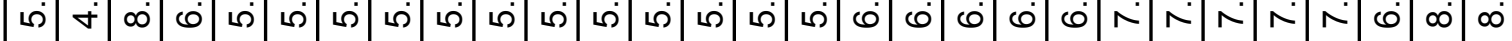
으울

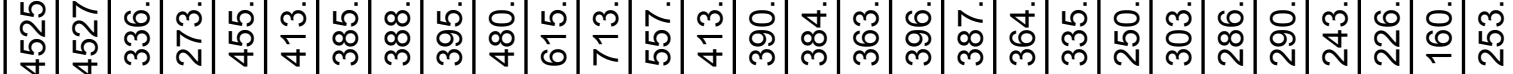

กิ

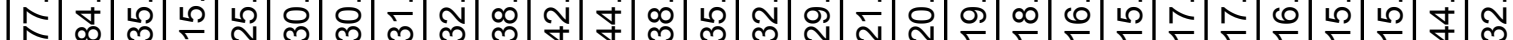

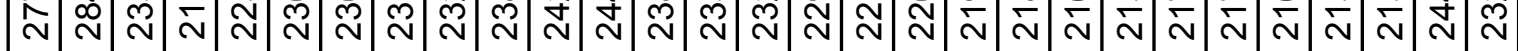

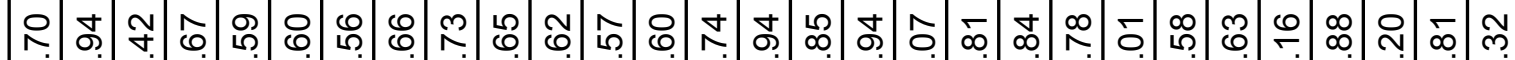

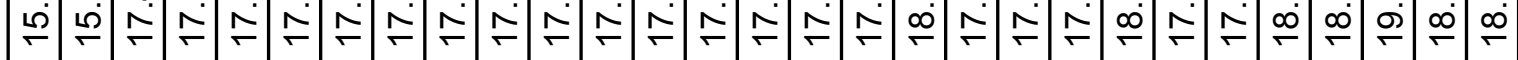
స్లి 年

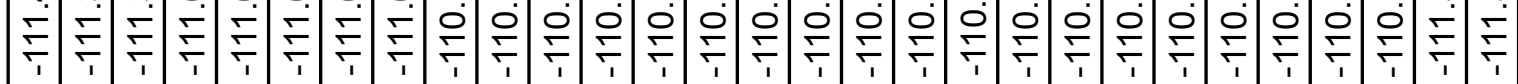

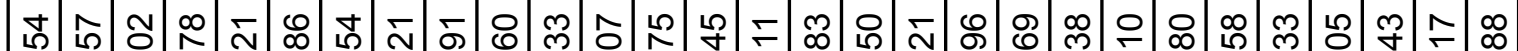
m)

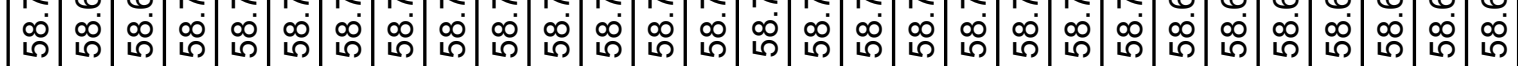

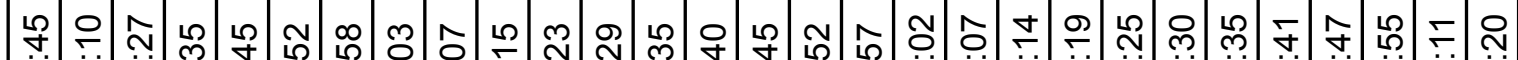

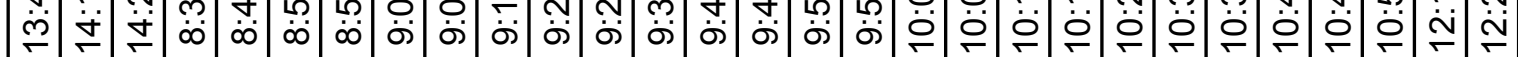

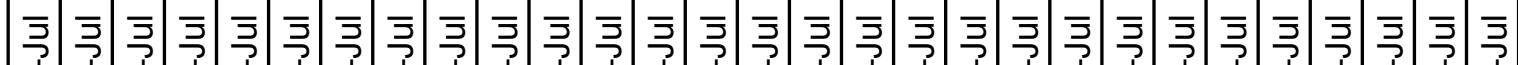

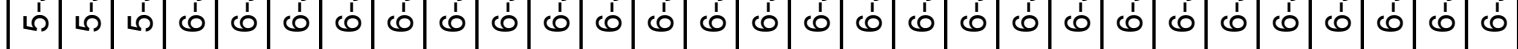

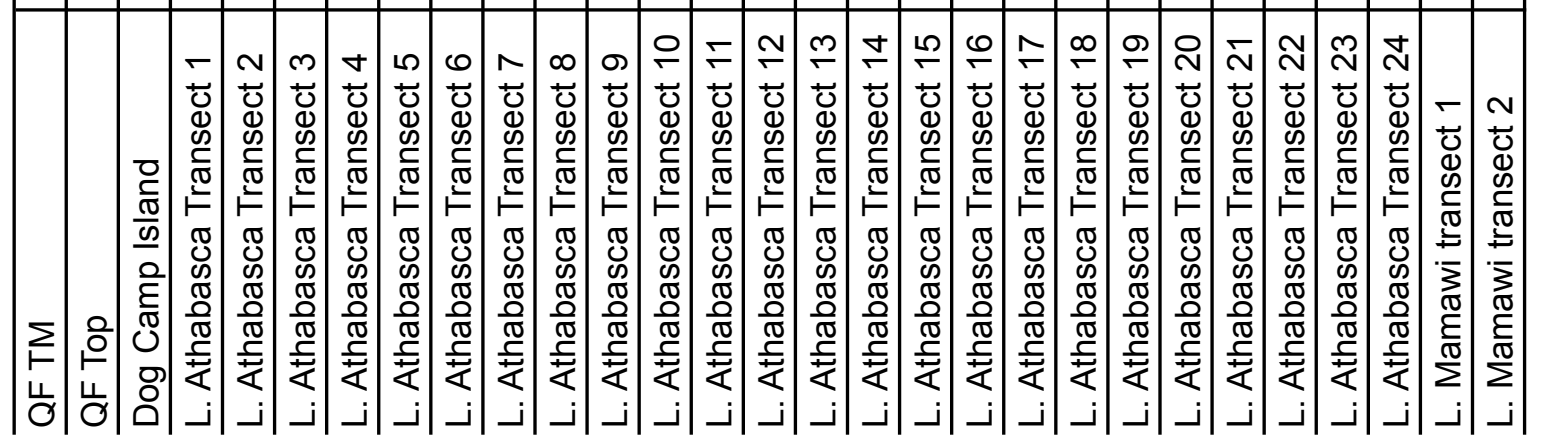




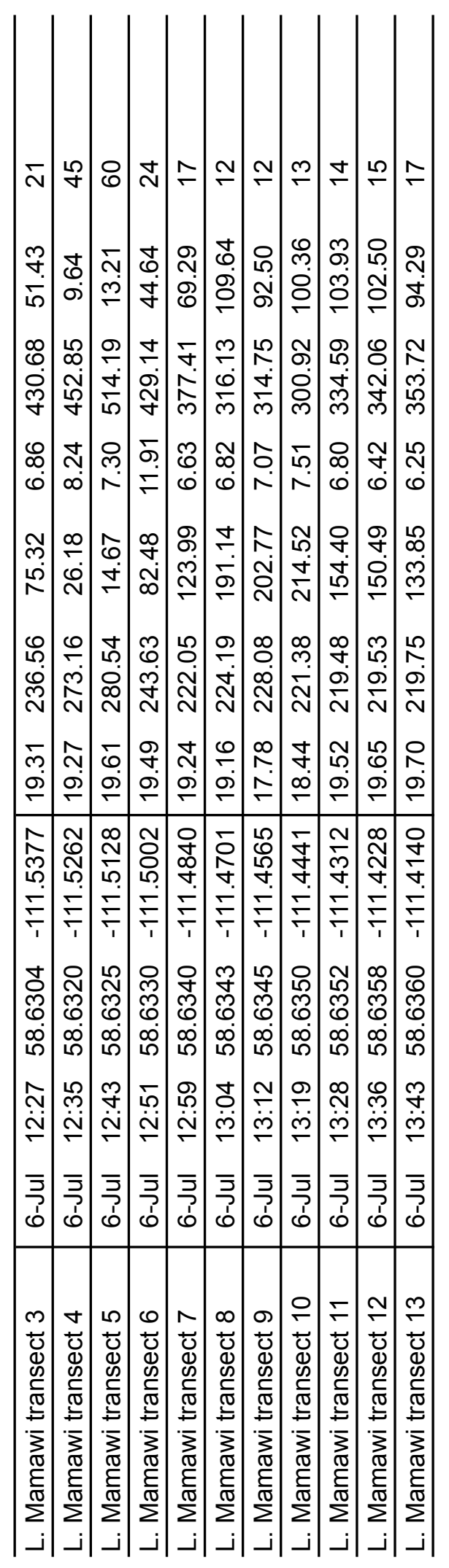


Appendix 2: In situ reflectance measurements

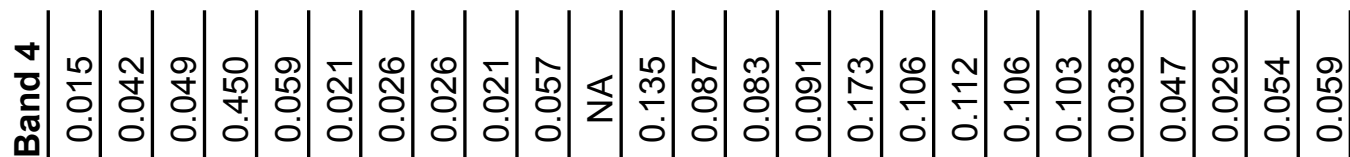

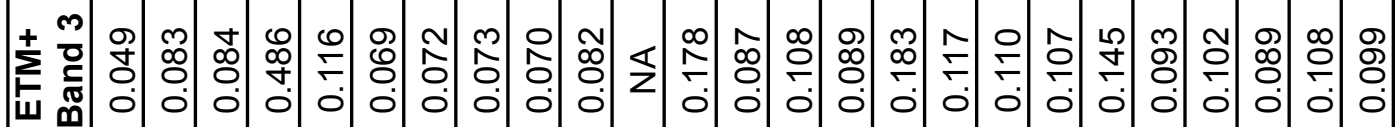
N

m m m m m $m$ m

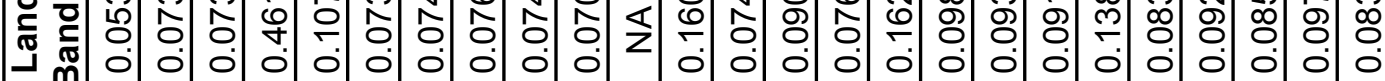

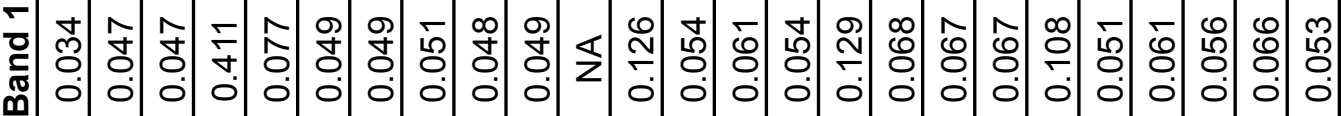

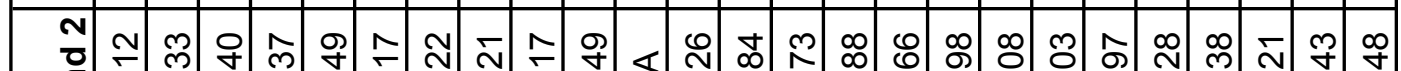

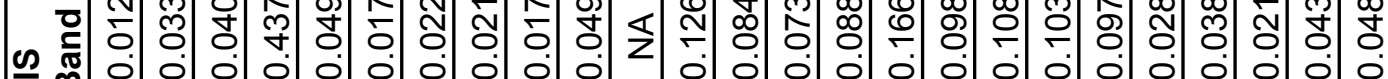

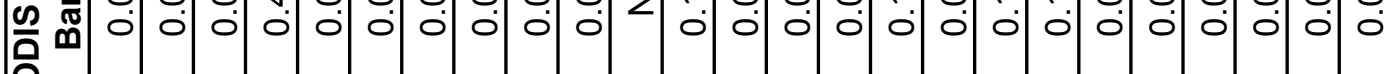

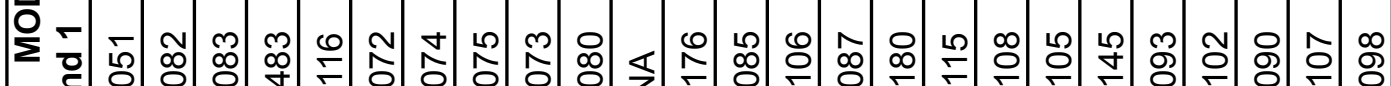

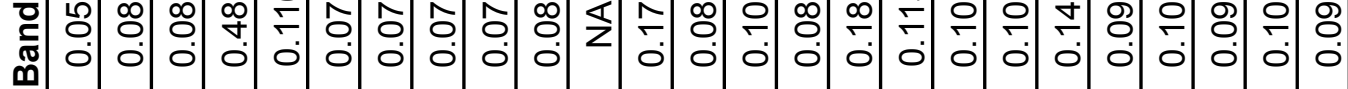
$\approx \stackrel{0}{0}$ 只

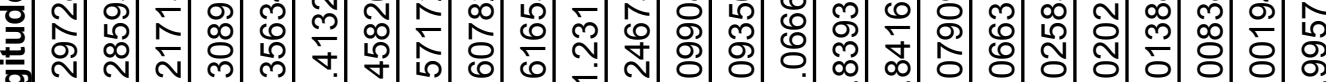

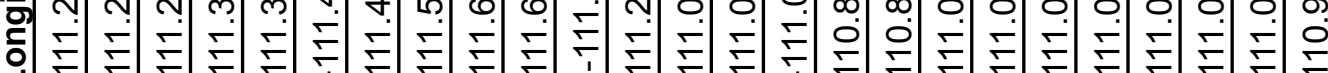
N

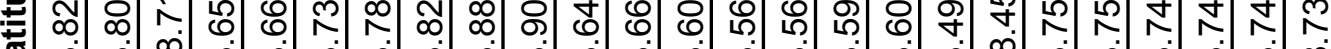

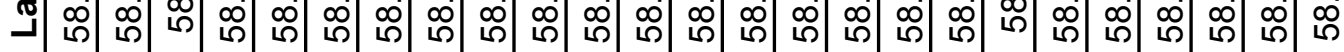

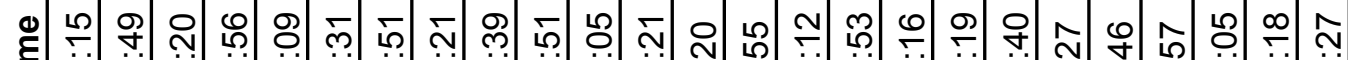

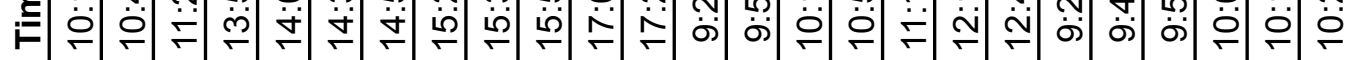

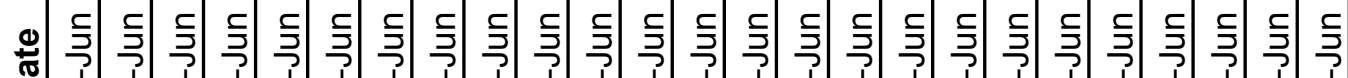
๑ d

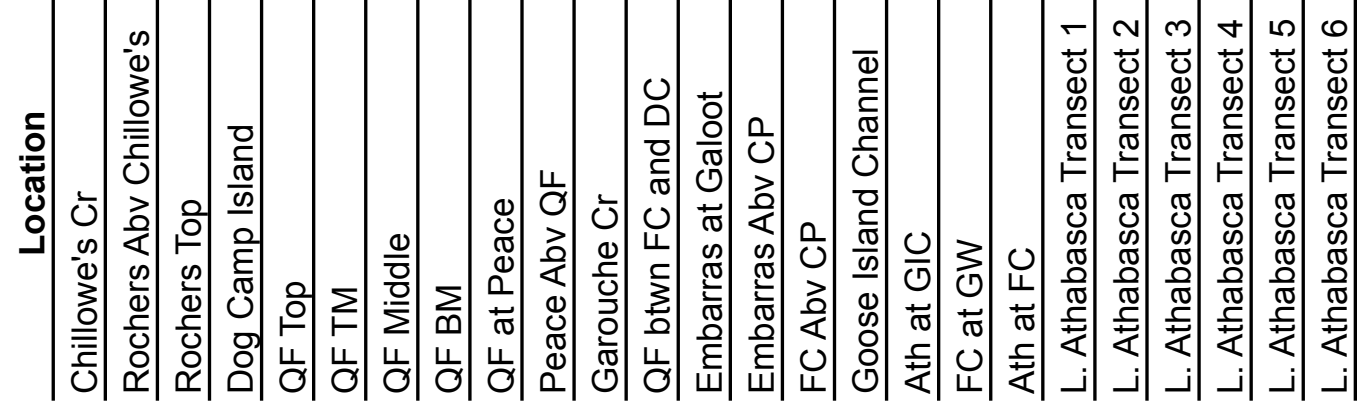




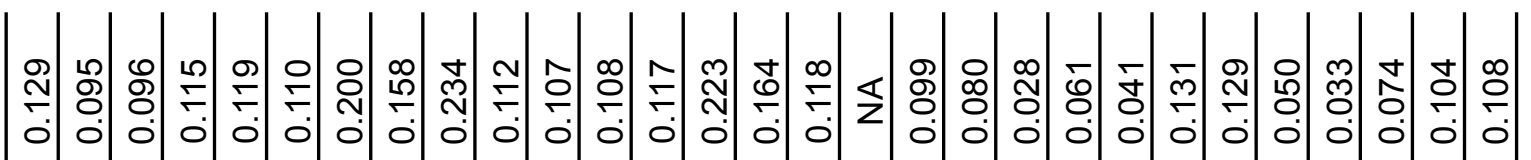

$\stackrel{0}{\circ}$ 足

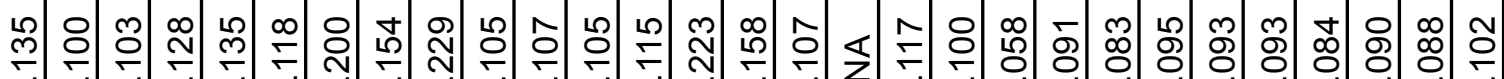

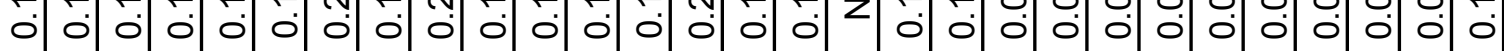

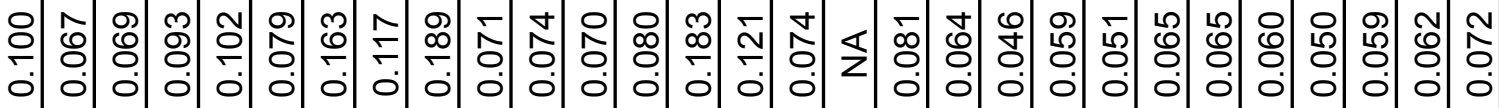

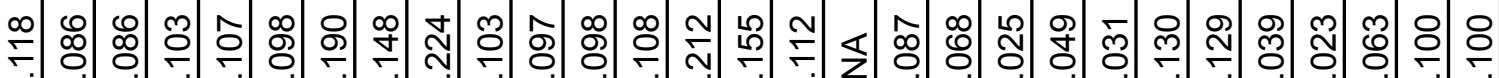

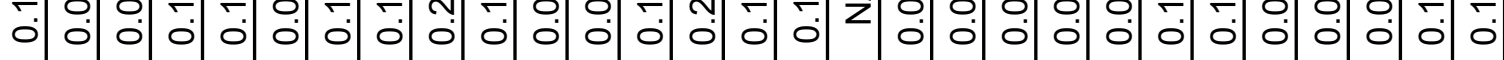

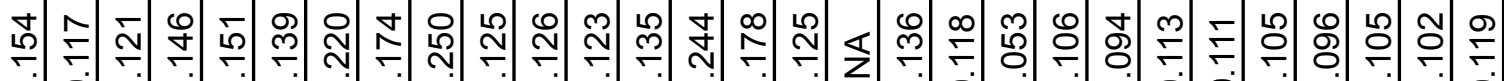

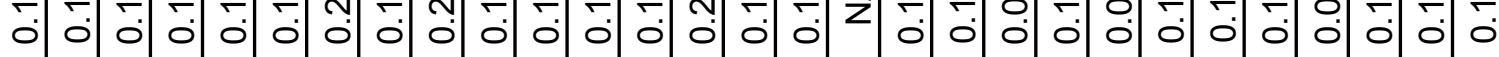

$\mathscr{0}$ œ ळ.

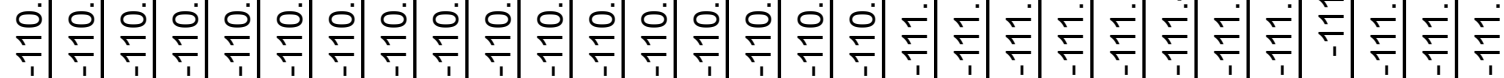

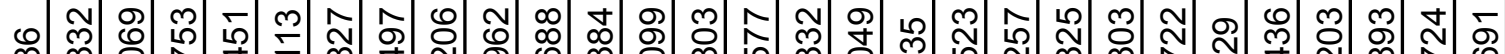

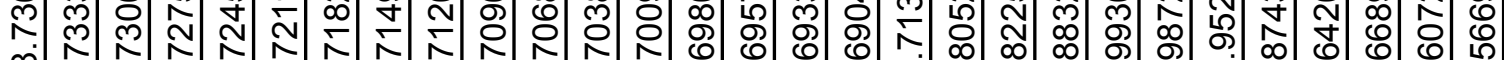

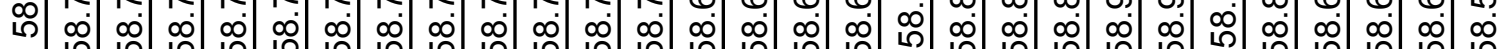

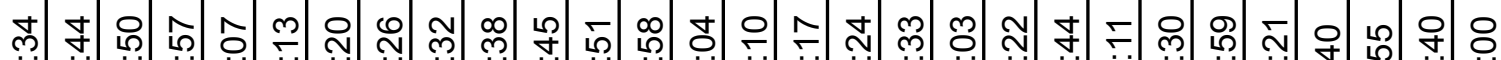

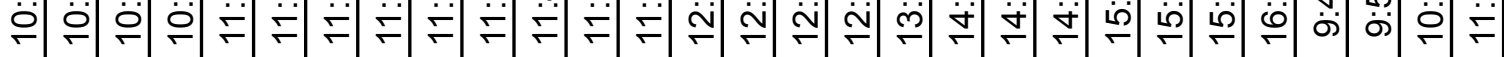

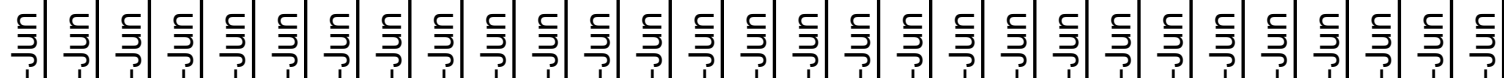

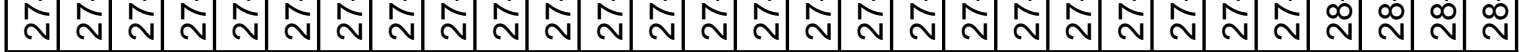

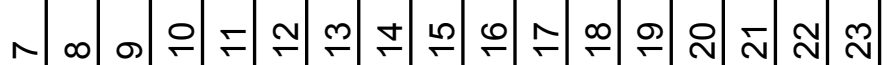

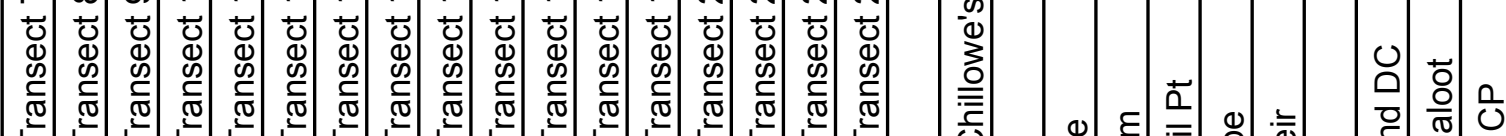

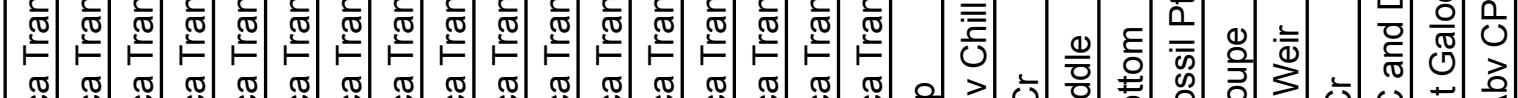

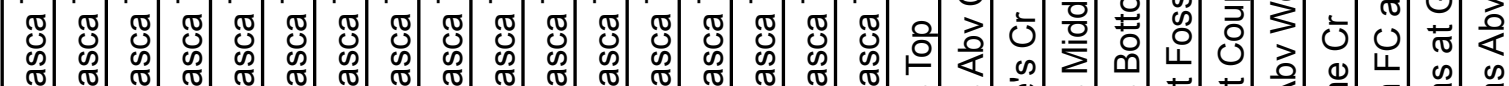

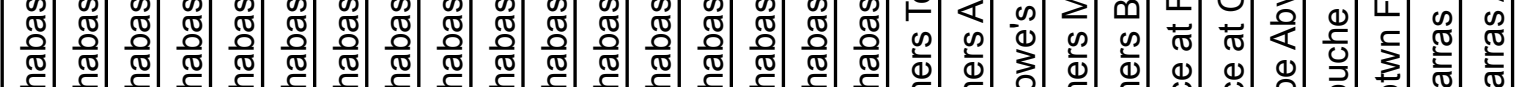

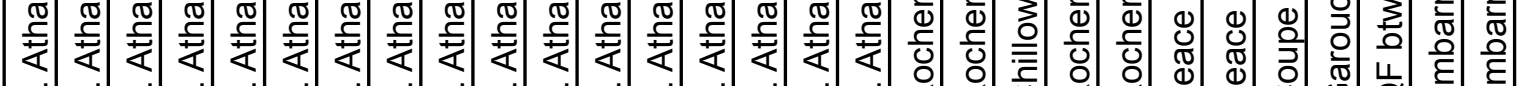

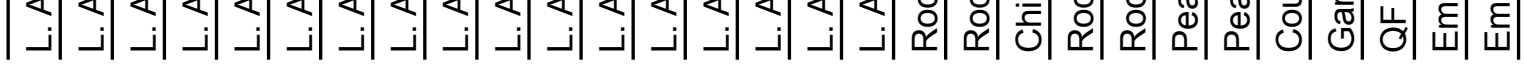


|

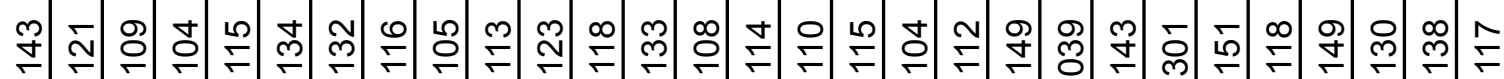

¿-

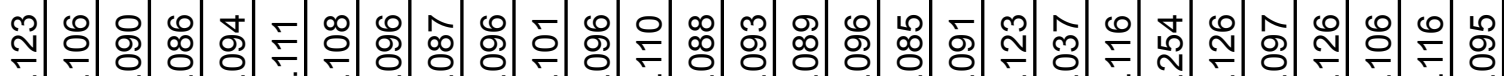

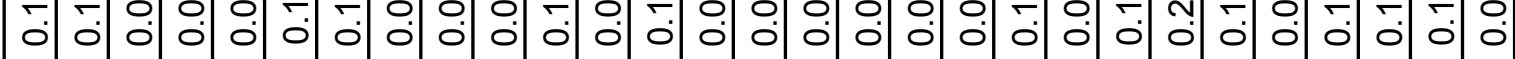

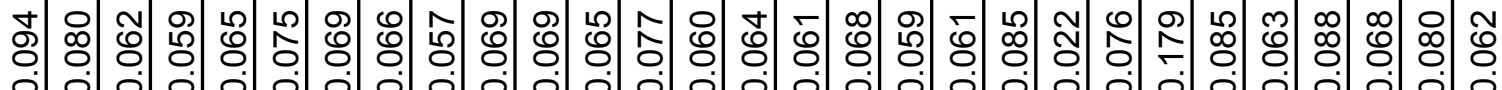

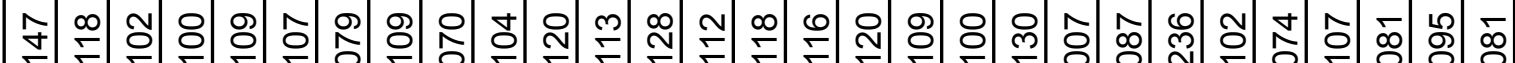

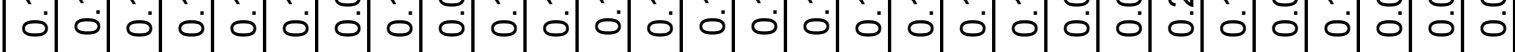

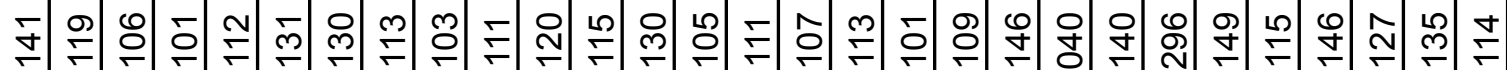

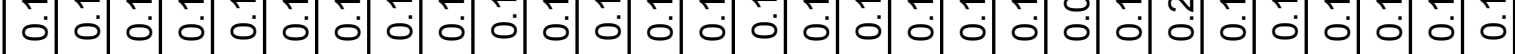

잉 :

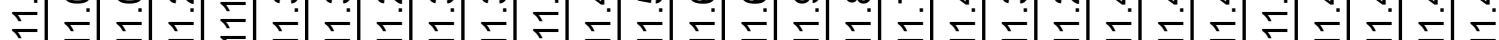

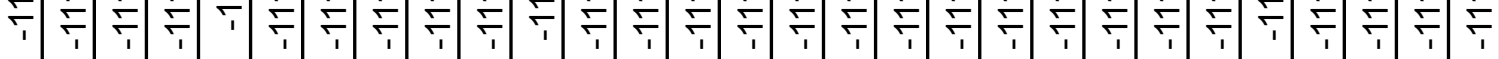

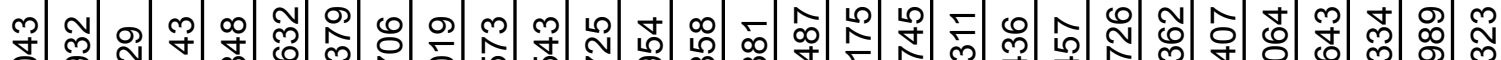

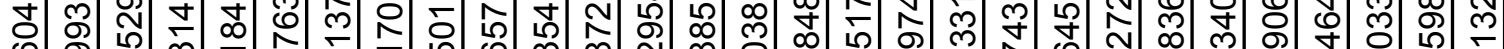

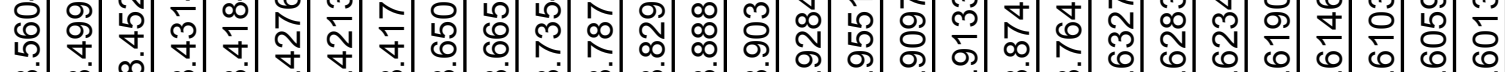

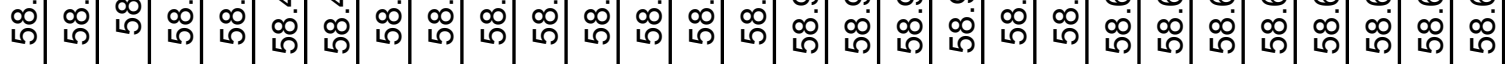

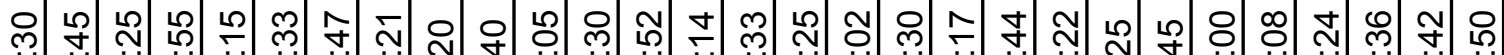

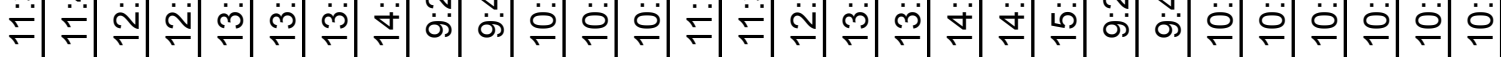

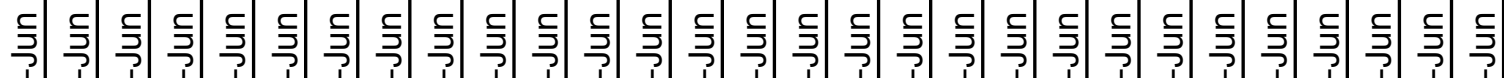

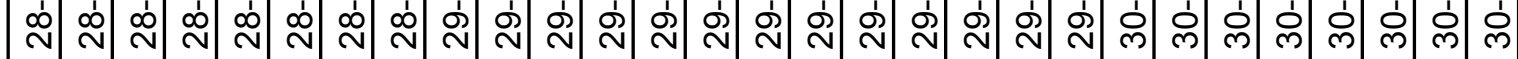

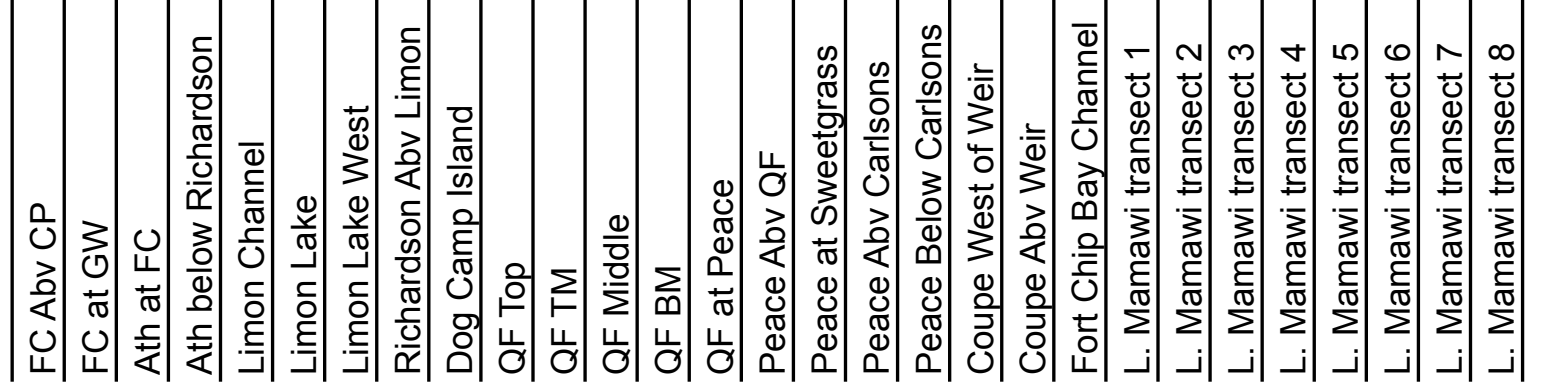




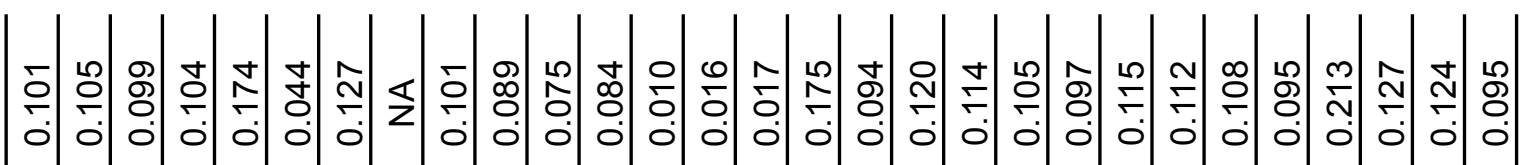

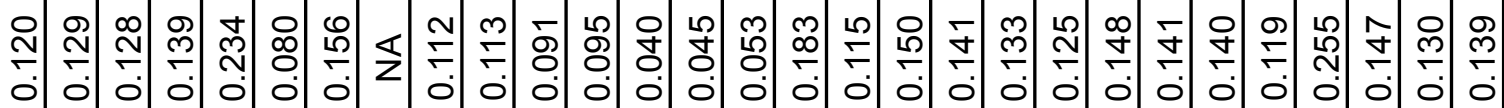

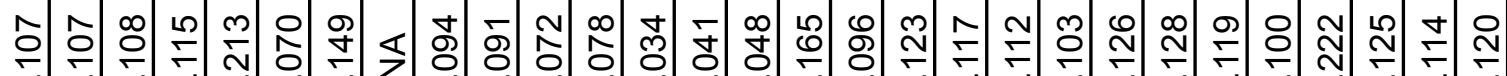

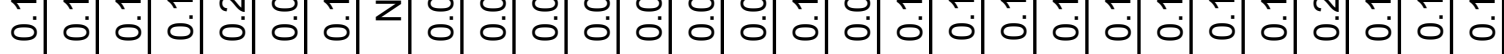

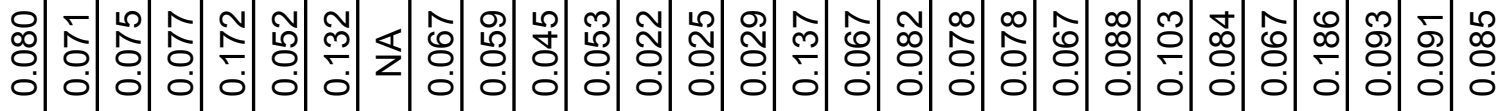

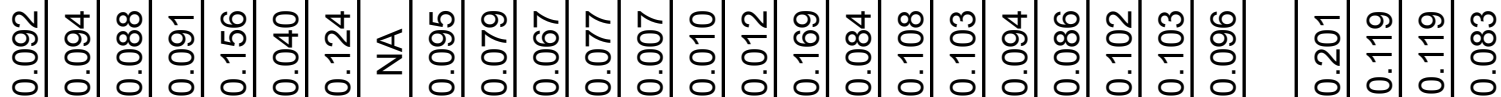

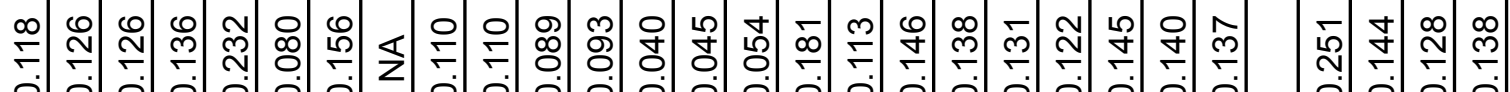

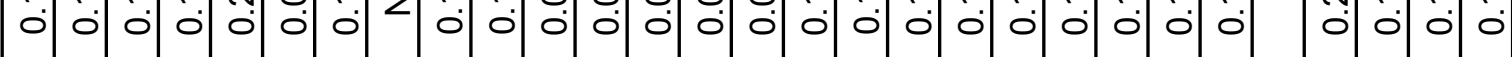

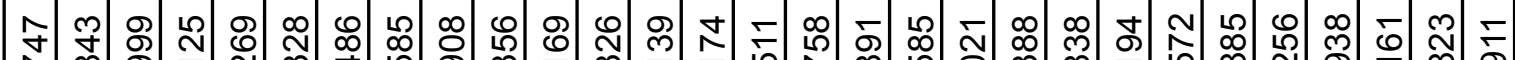

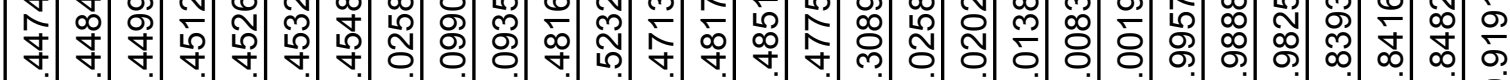

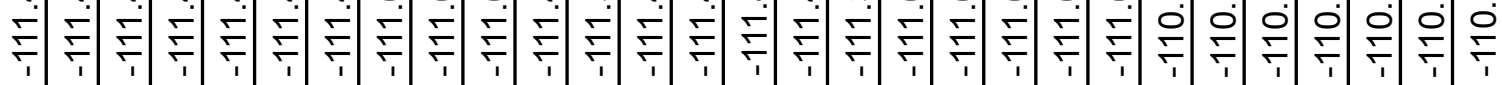

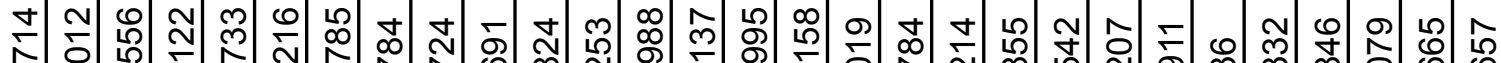

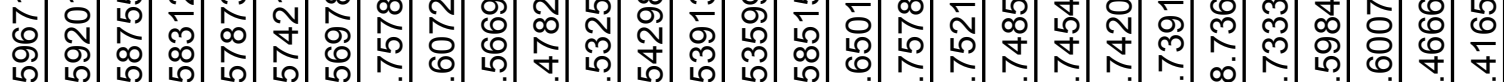

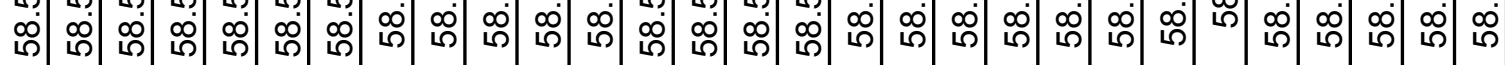

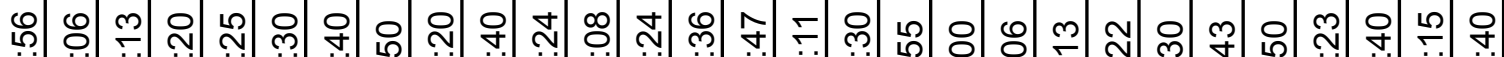

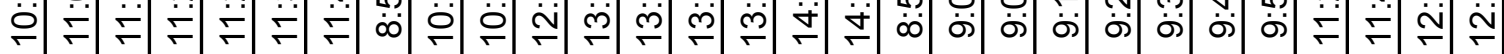

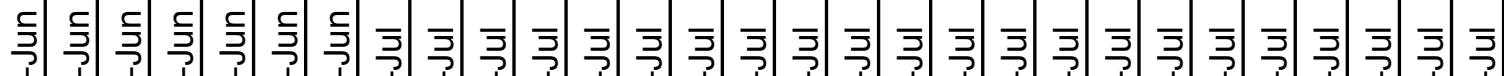
ठิ

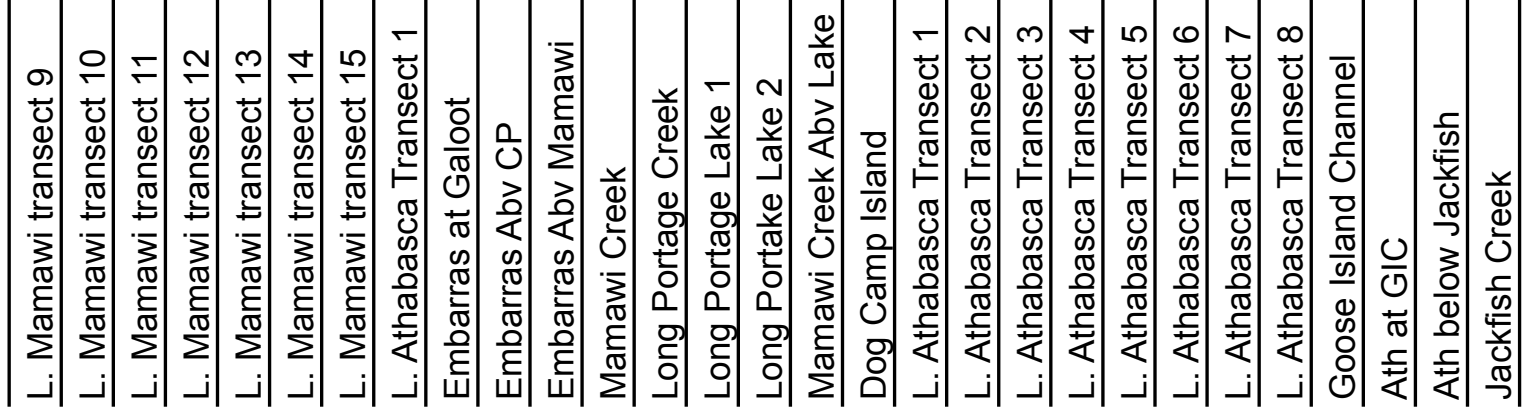




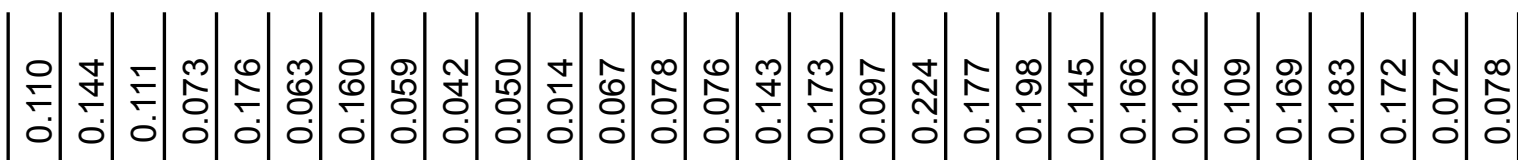

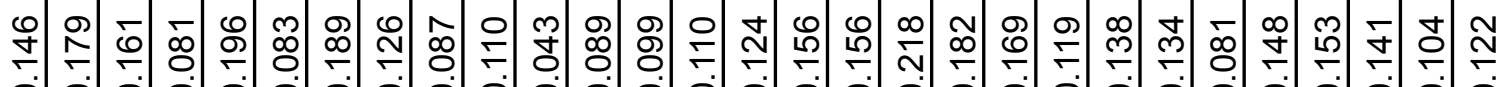

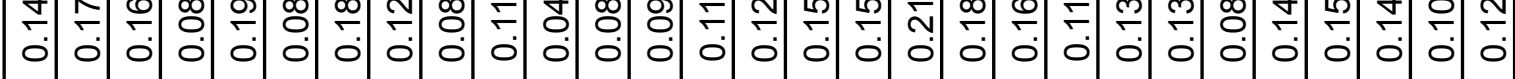

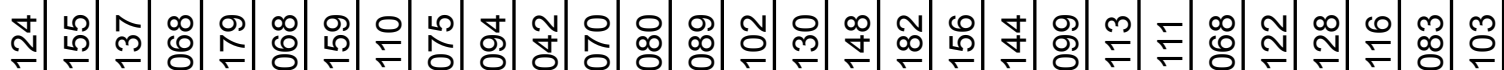
o. ó.

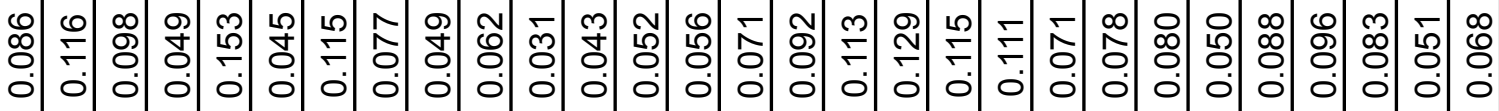

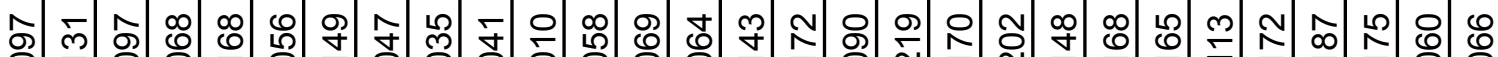

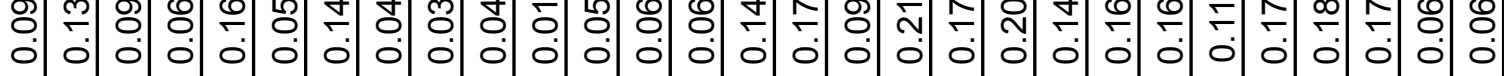

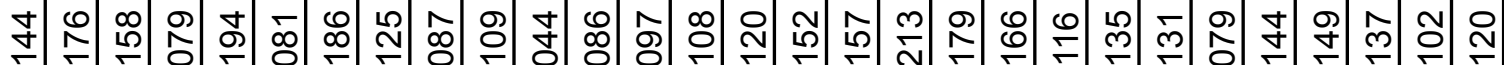

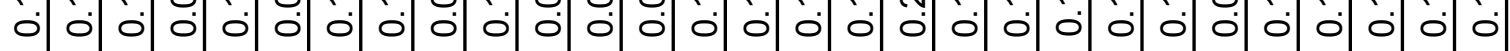

志 స

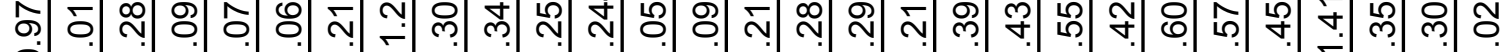

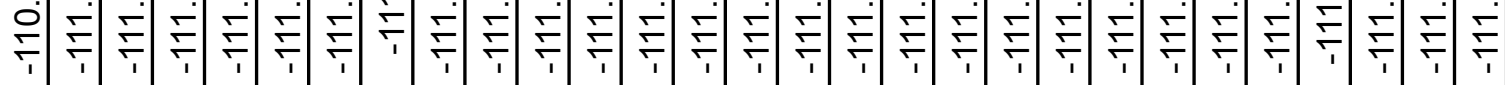

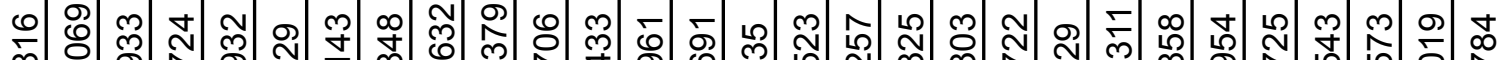

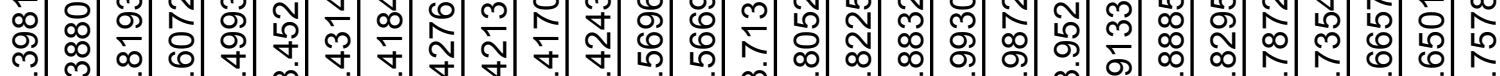

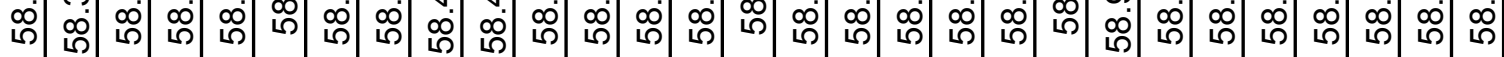

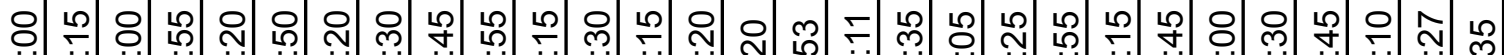
ஸ் 引 引

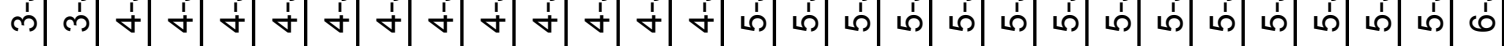

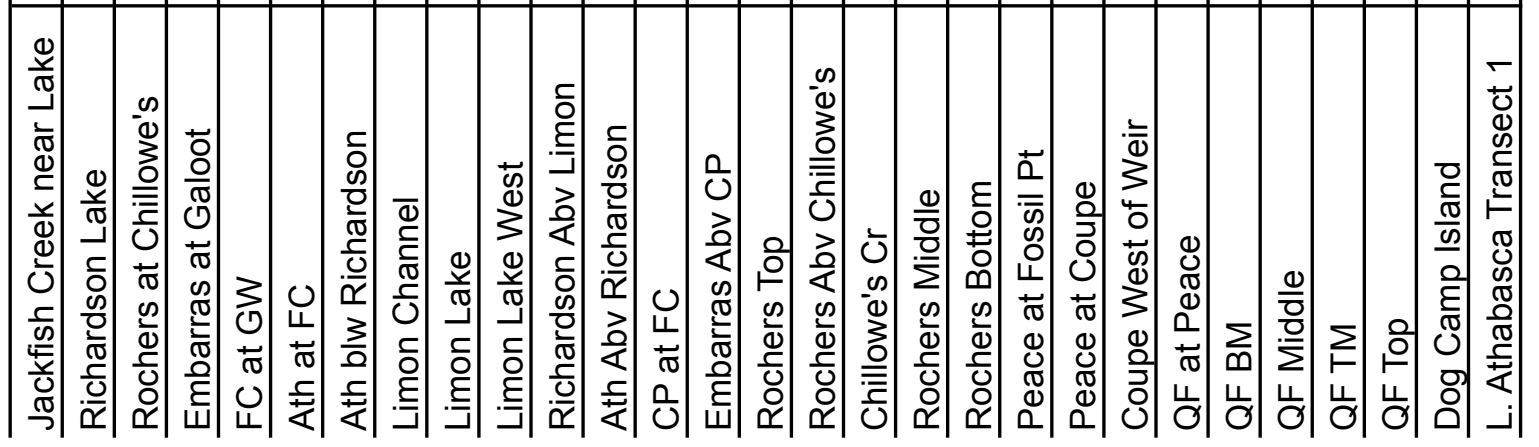




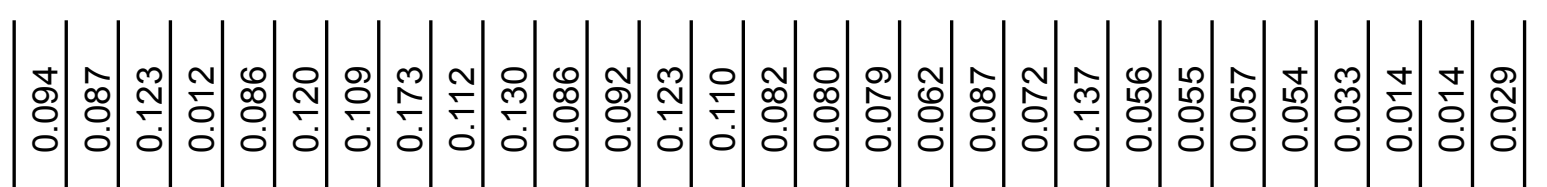

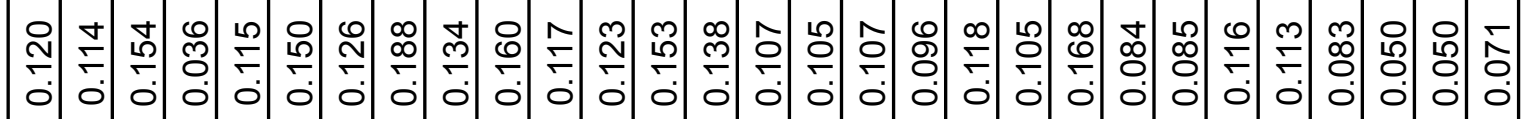

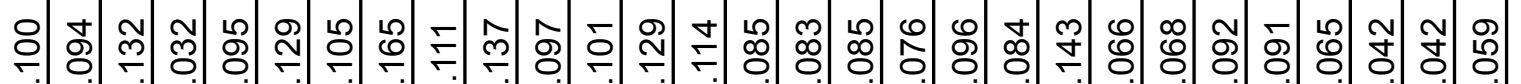

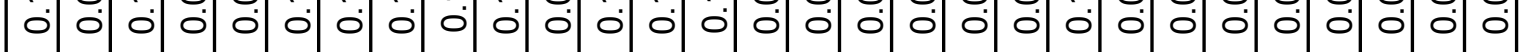

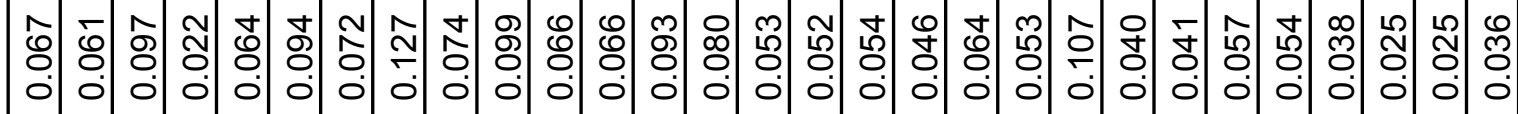

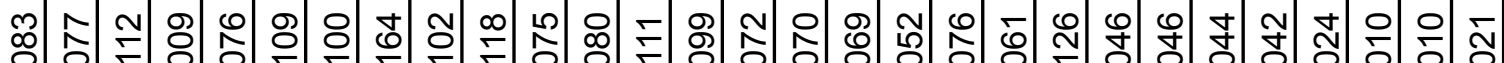

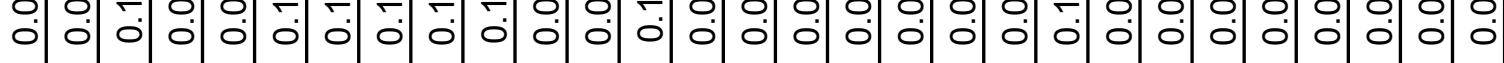

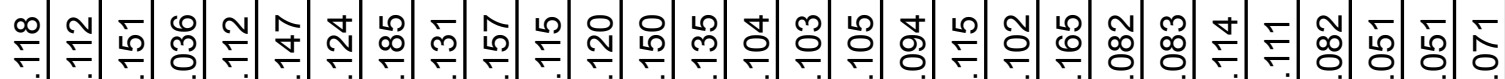

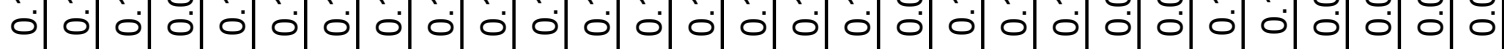

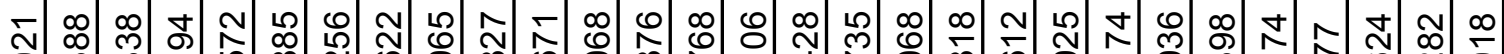

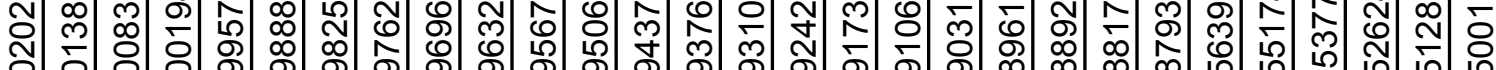

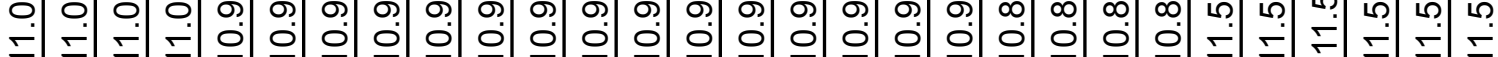
$\because \div \div \div \div \div \div \div \div \div \div \div \div \div \div$

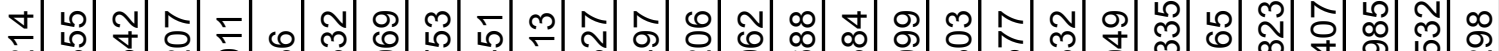

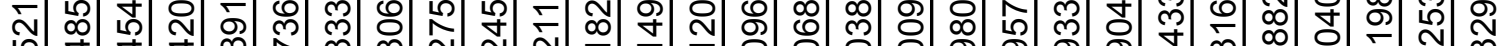

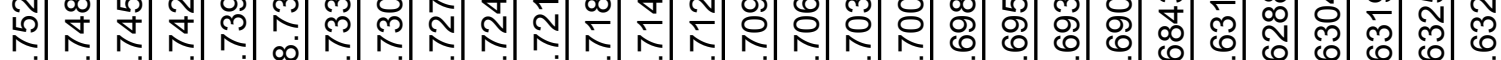

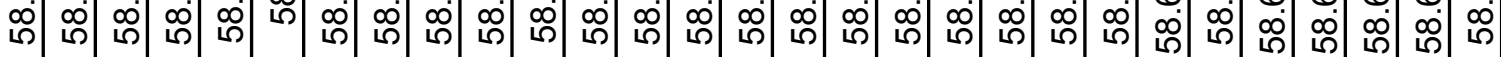

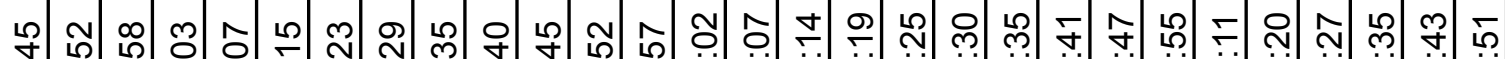

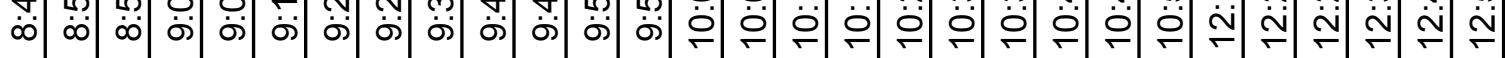

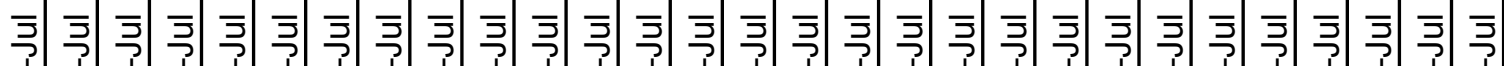

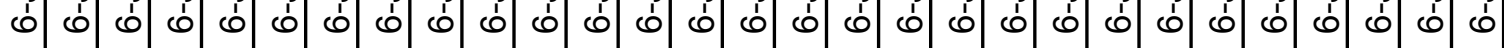
N

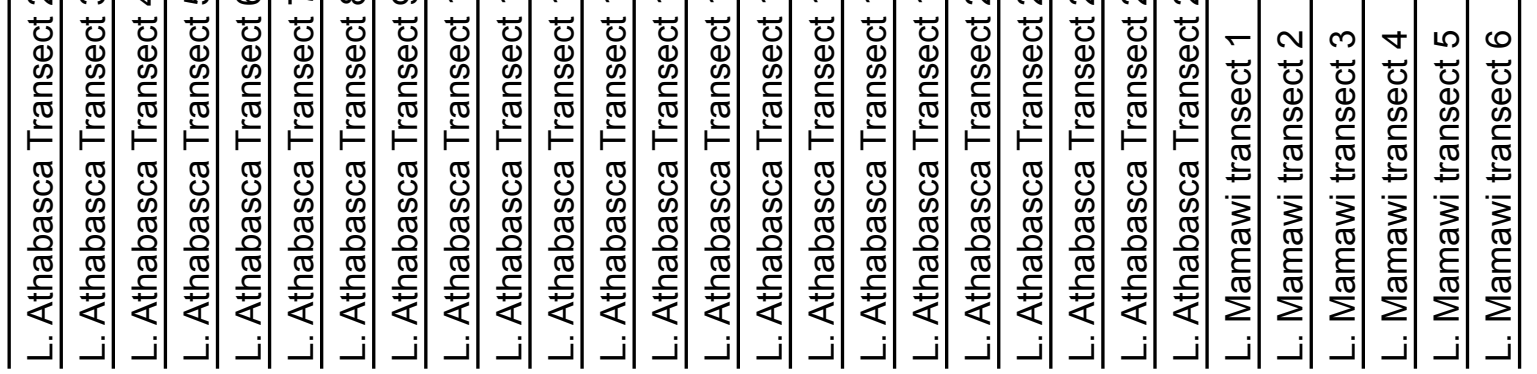




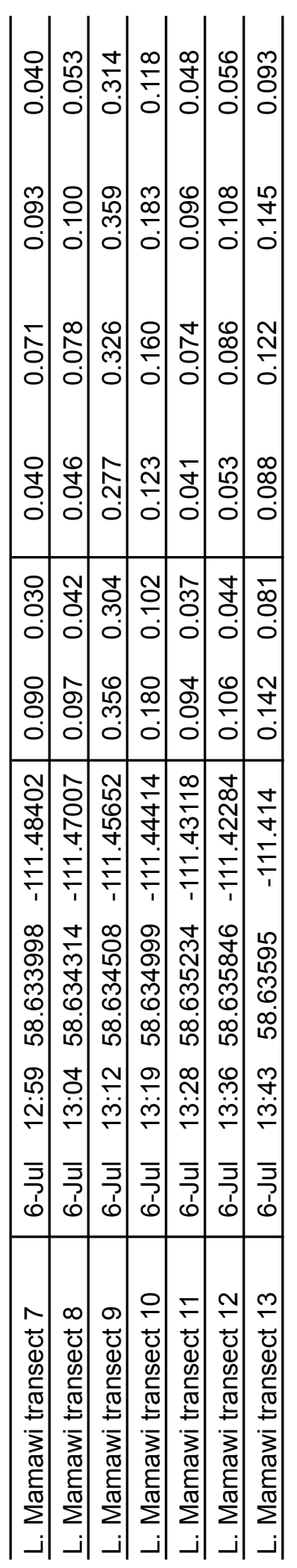


Appendix 3: Sediment Area Index time series for floodplain lakes
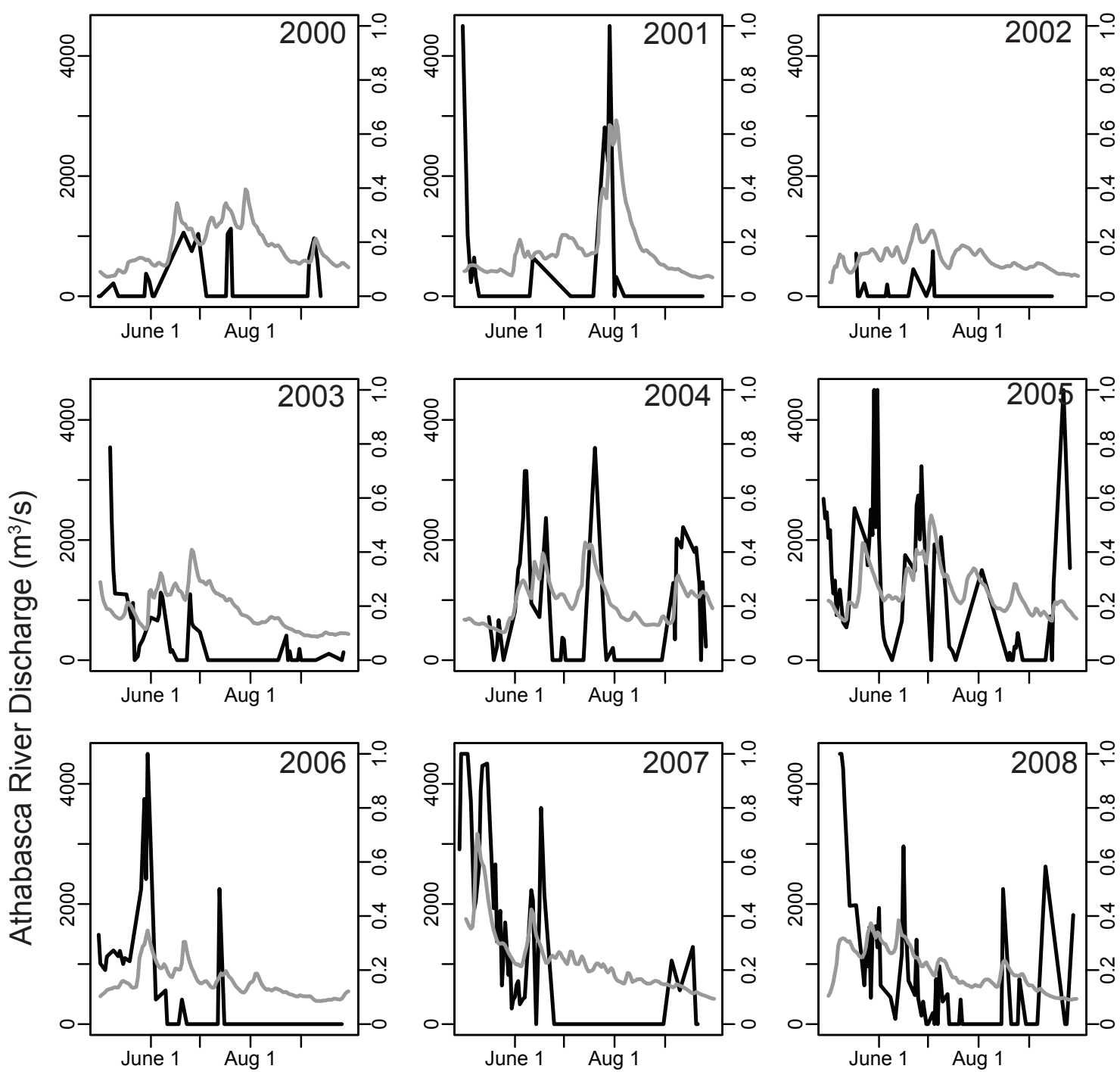

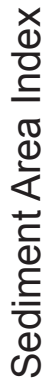
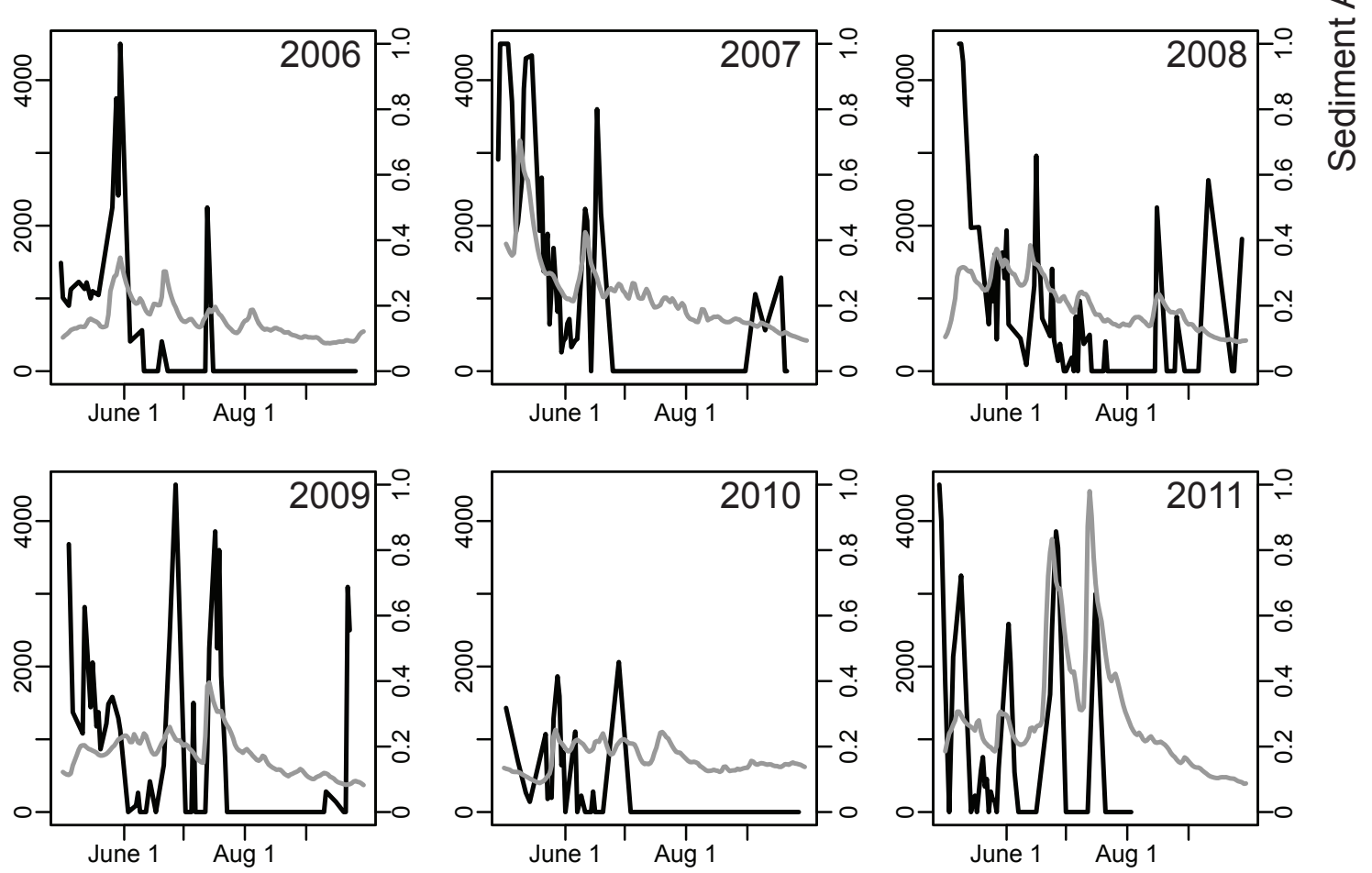

Sediment Area Index

Athabasca River discharge

Annual time series of Athabasca River discharge and remotely sensed sediment area index (proportion of lake area with high sediment water) for Lake 1 (Long Portage Lake) 

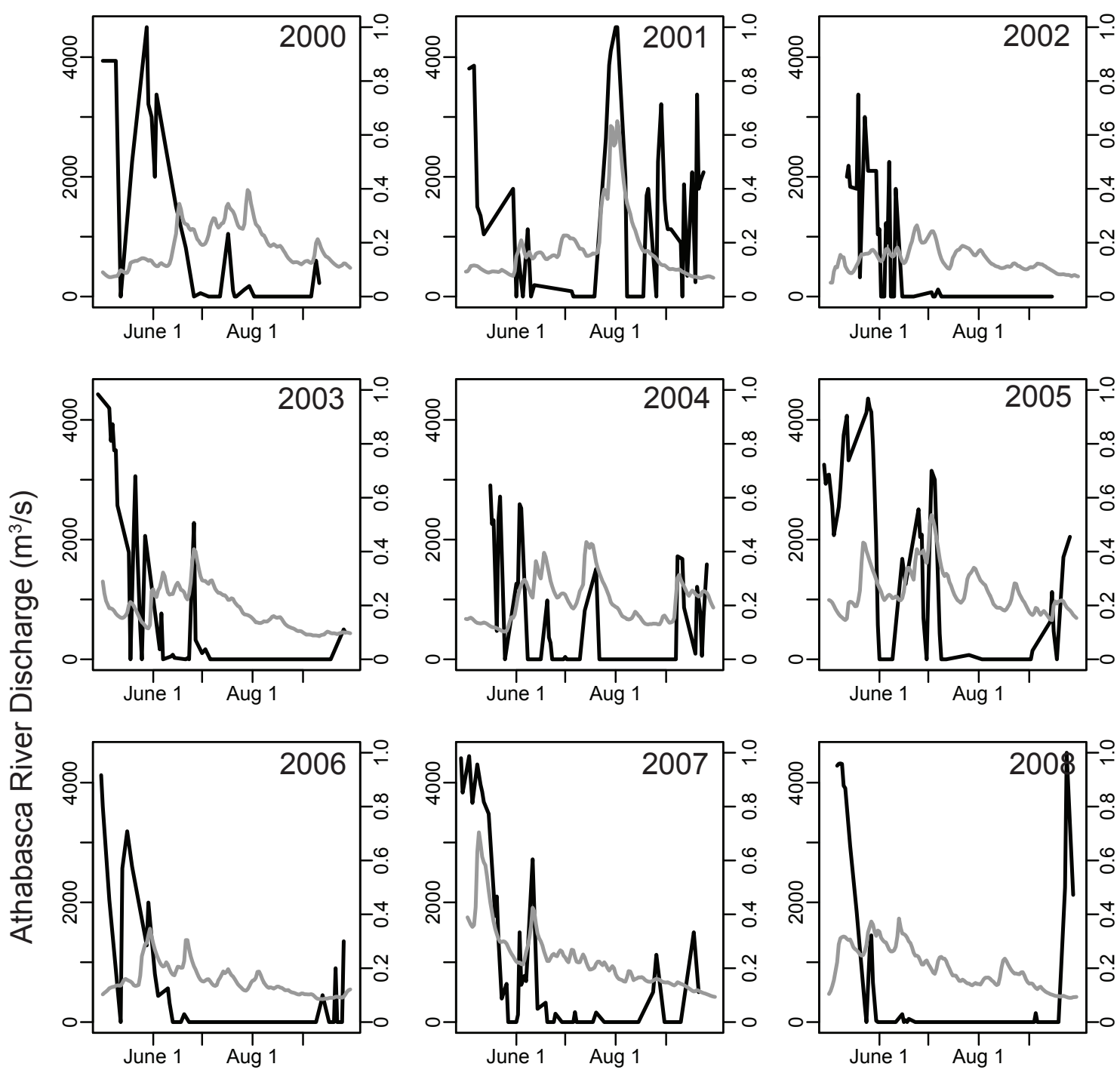

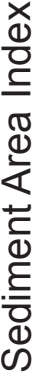
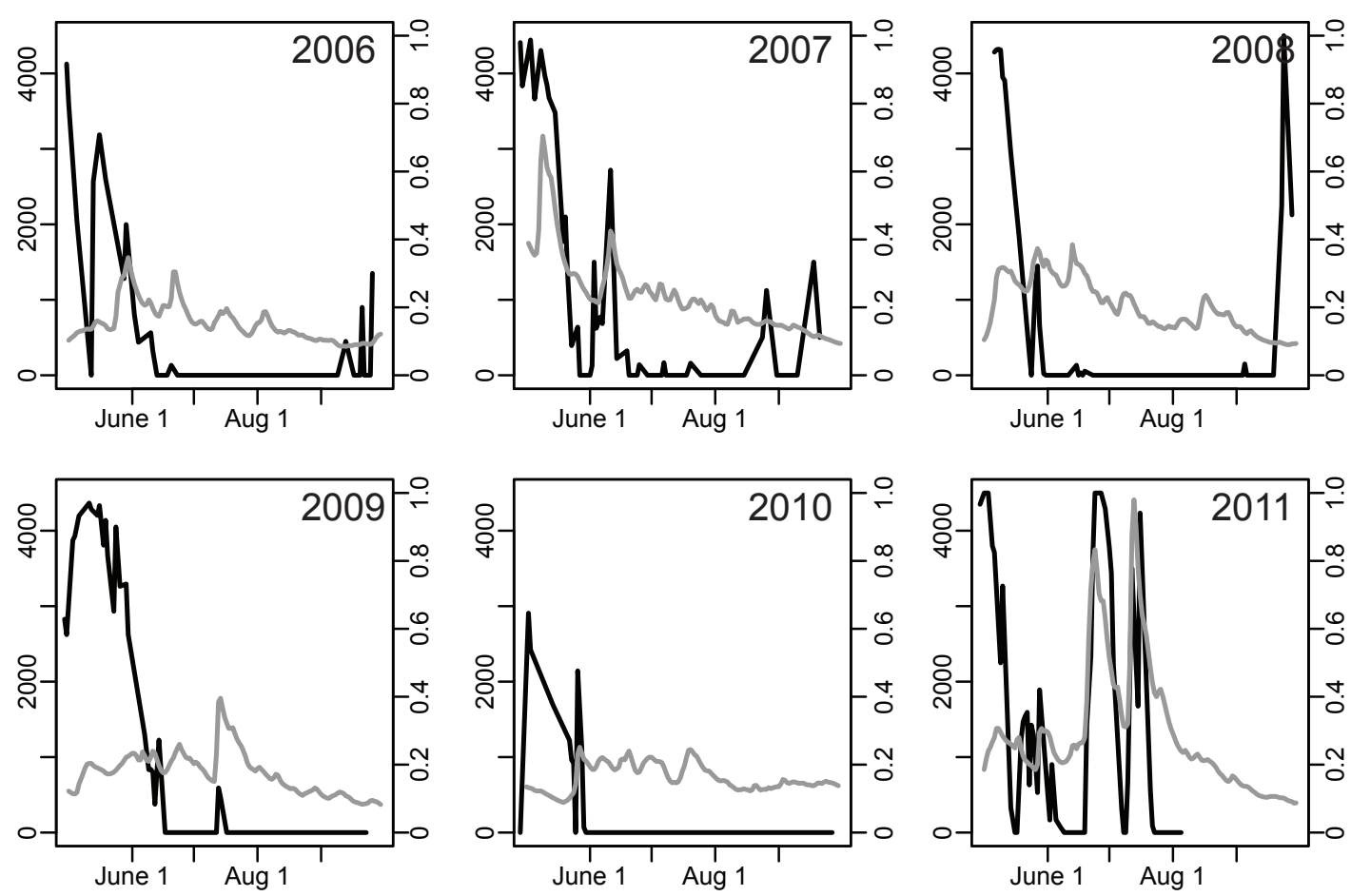

Sediment Area Index

Athabasca River discharge

Annual time series of Athabasca River discharge and remotely sensed sediment area index (proportion of lake area with high sediment water) for Lake 2 (Limon Lake) 

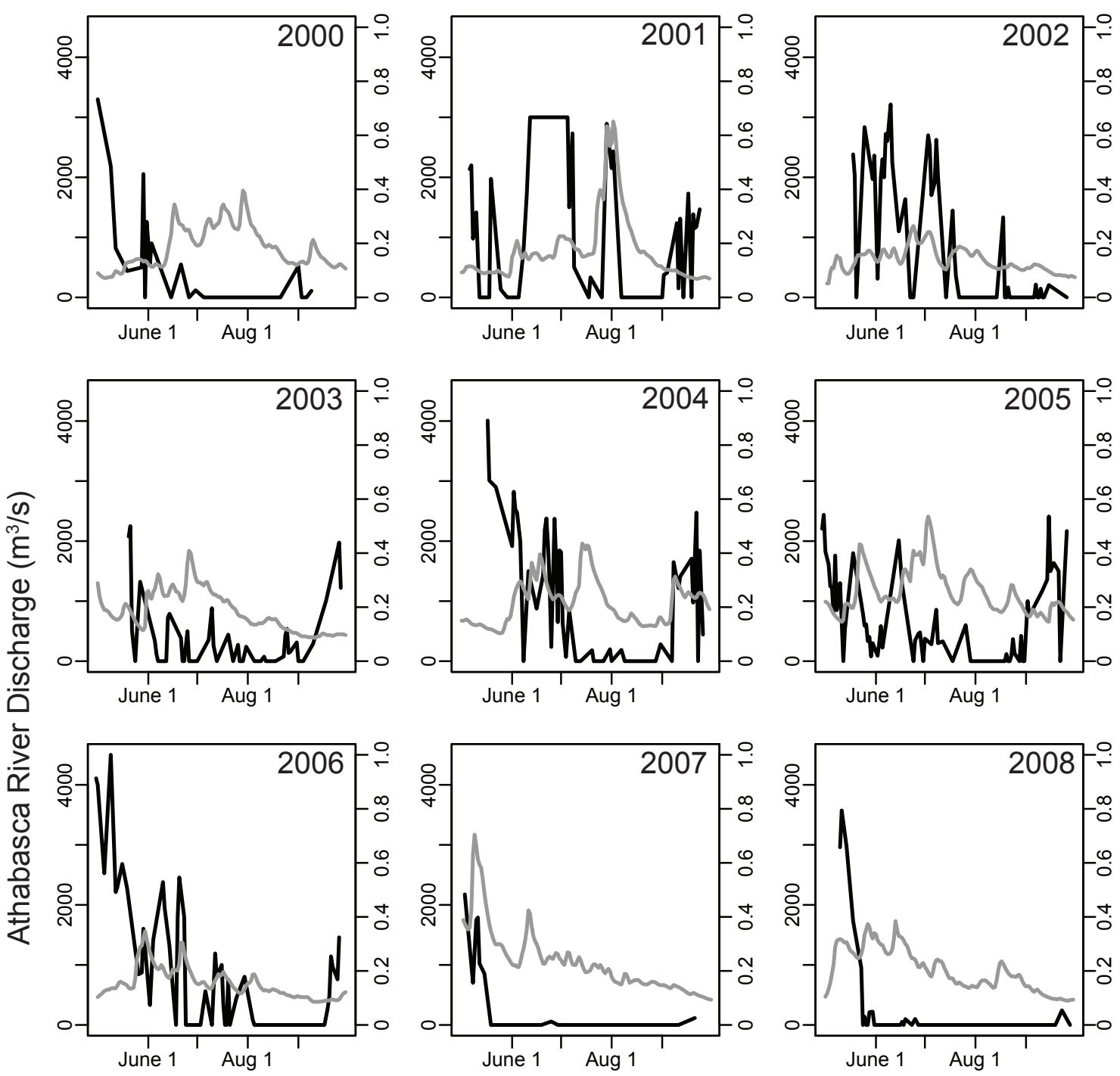

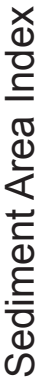
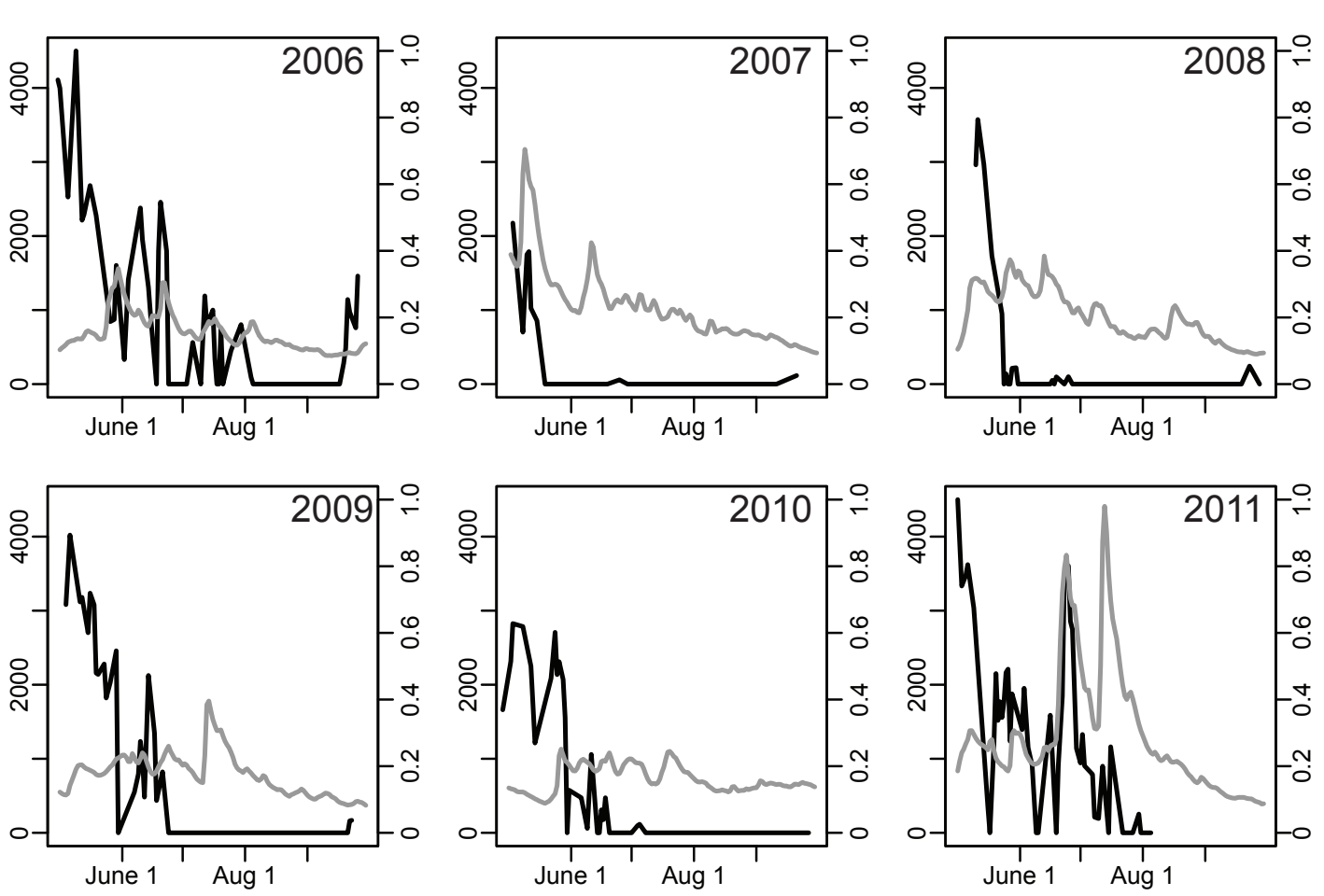

Sediment Area Index

Athabasca River discharge

Annual time series of Athabasca River discharge and remotely sensed sediment area index (proportion of lake area with high sediment water) for Lake 3 (Blanche Lake) 

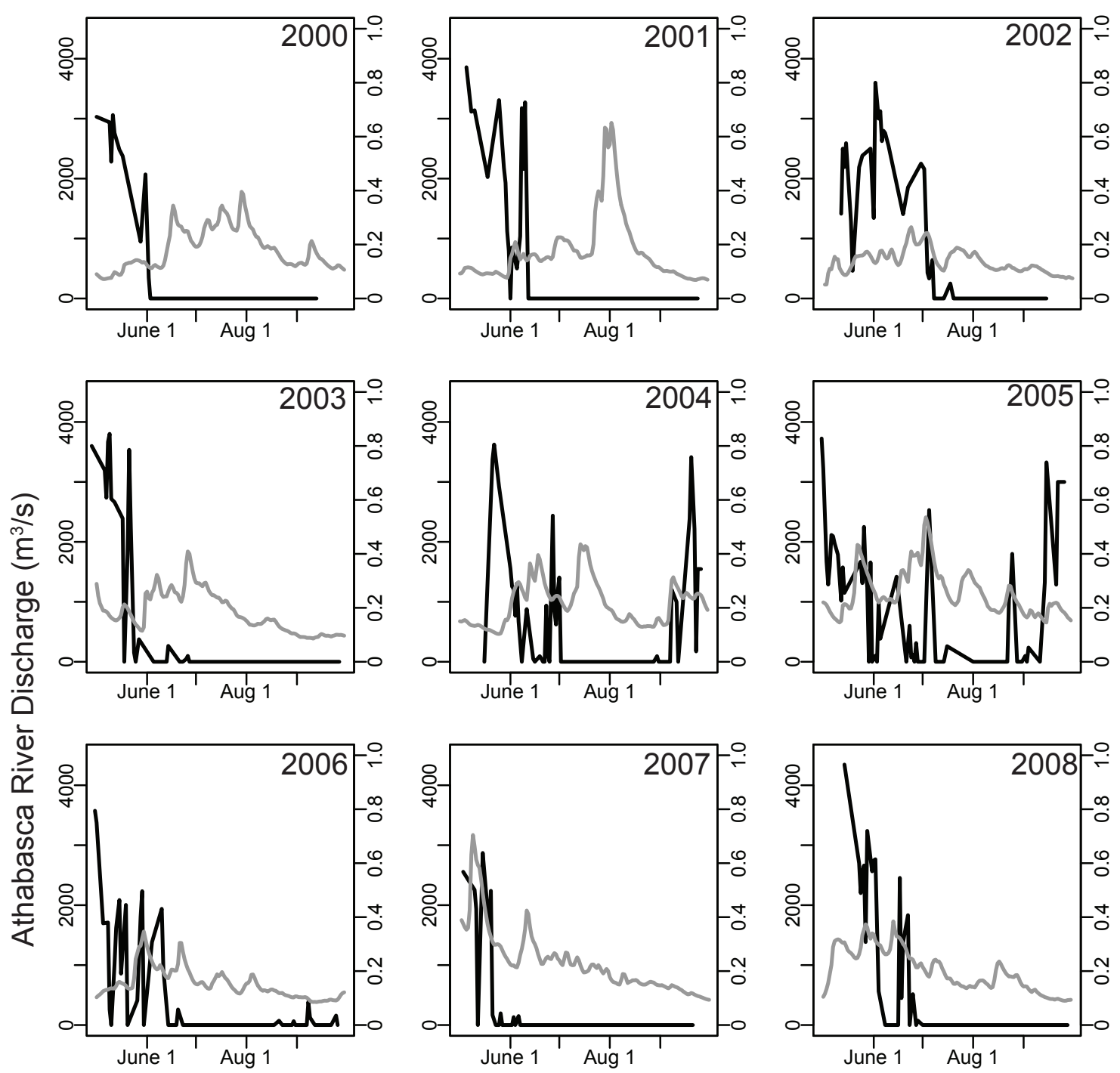

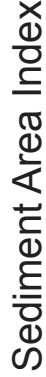
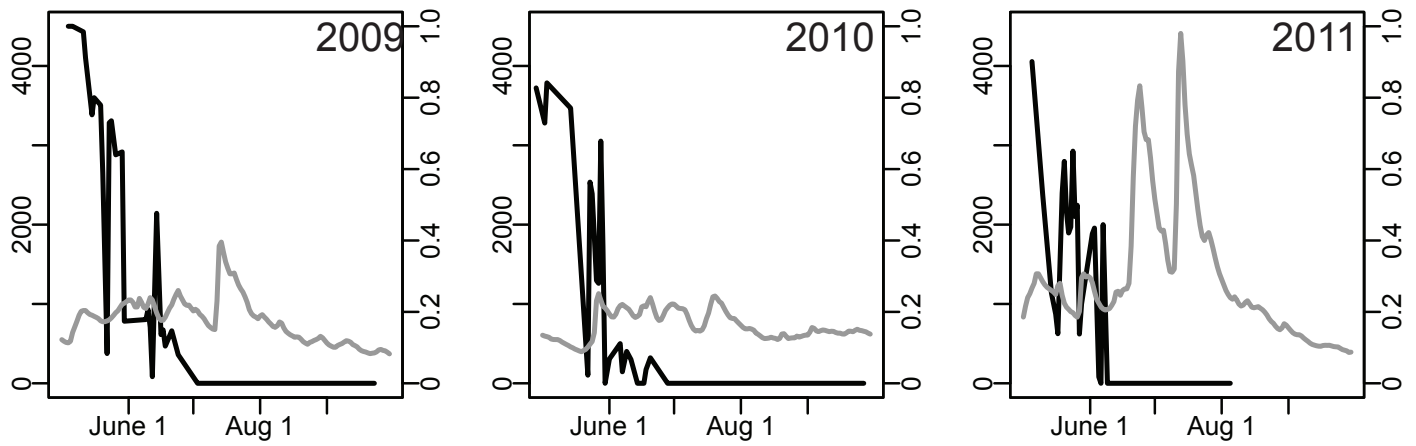

\section{Sediment Area Index}

Athabasca River discharge

Annual time series of Athabasca River discharge and remotely sensed sediment area index (proportion of lake area with high sediment water) for Lake 4 (Big Lake) 

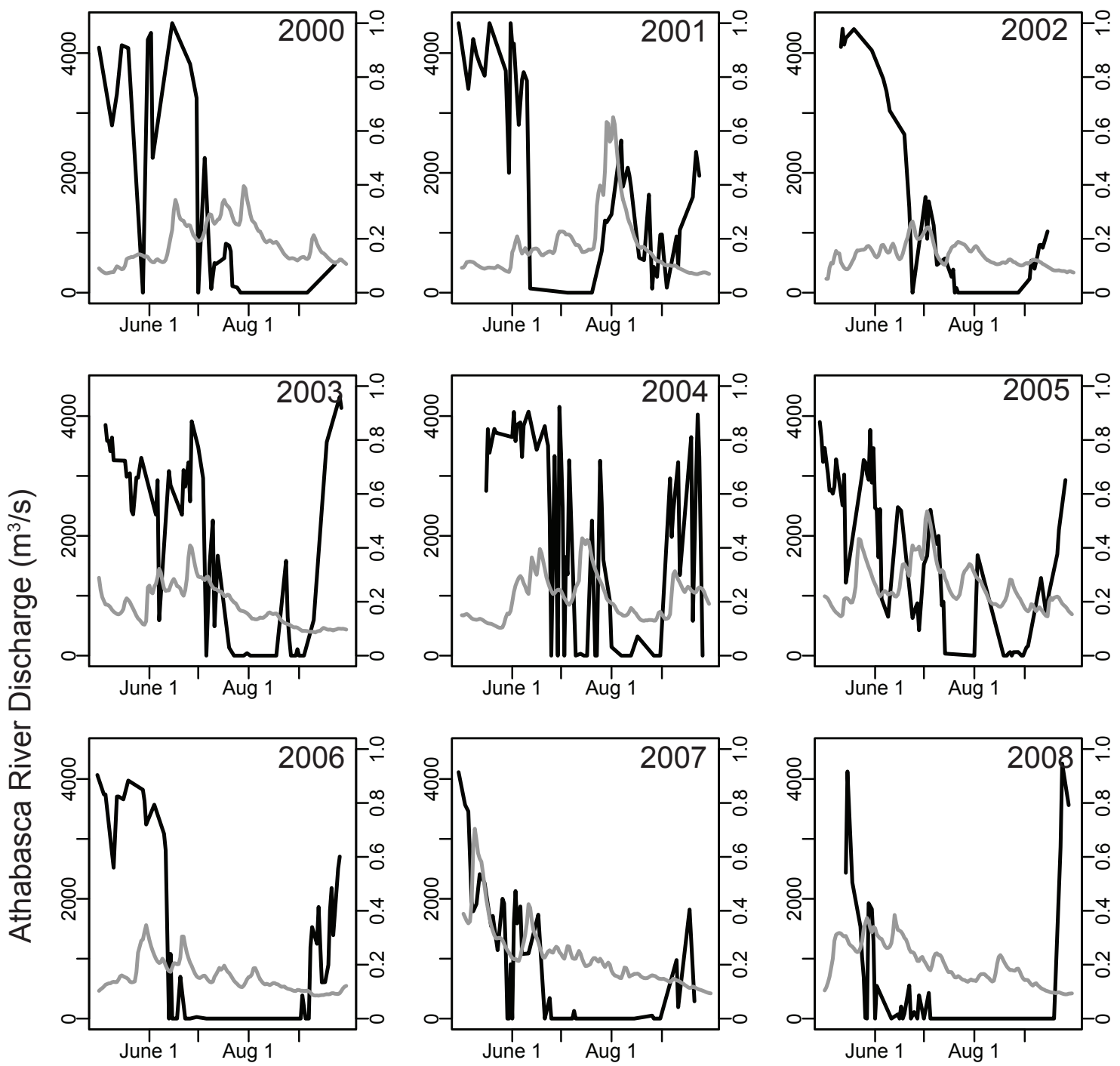

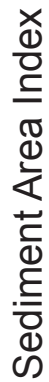
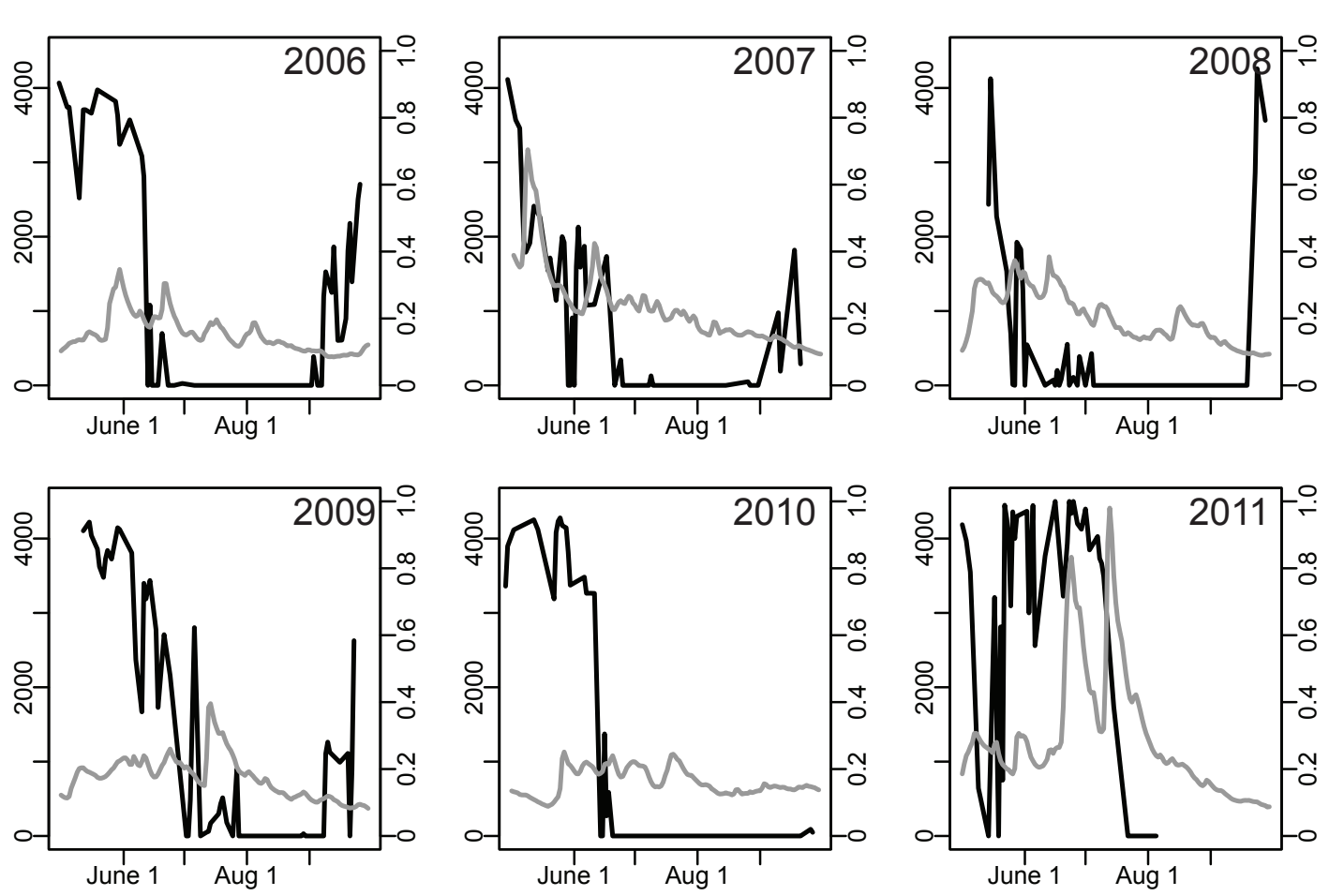

\section{Sediment Area Index \\ Athabasca River discharge}

Annual time series of Athabasca River discharge and remotely sensed sediment area index (proportion of lake area with high sediment water) for Lake 5 (Gray Wavy Lake) 

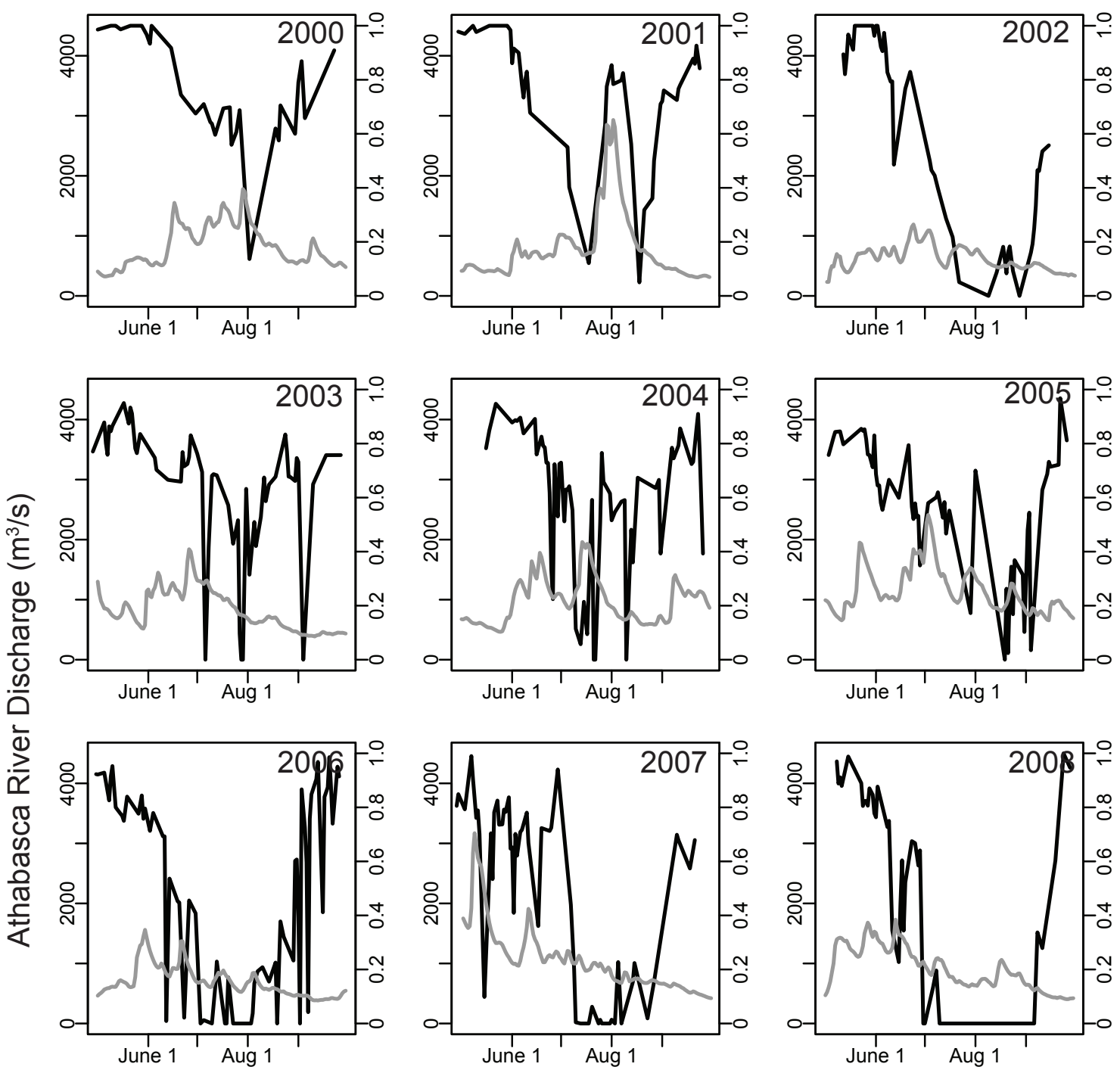

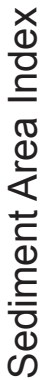
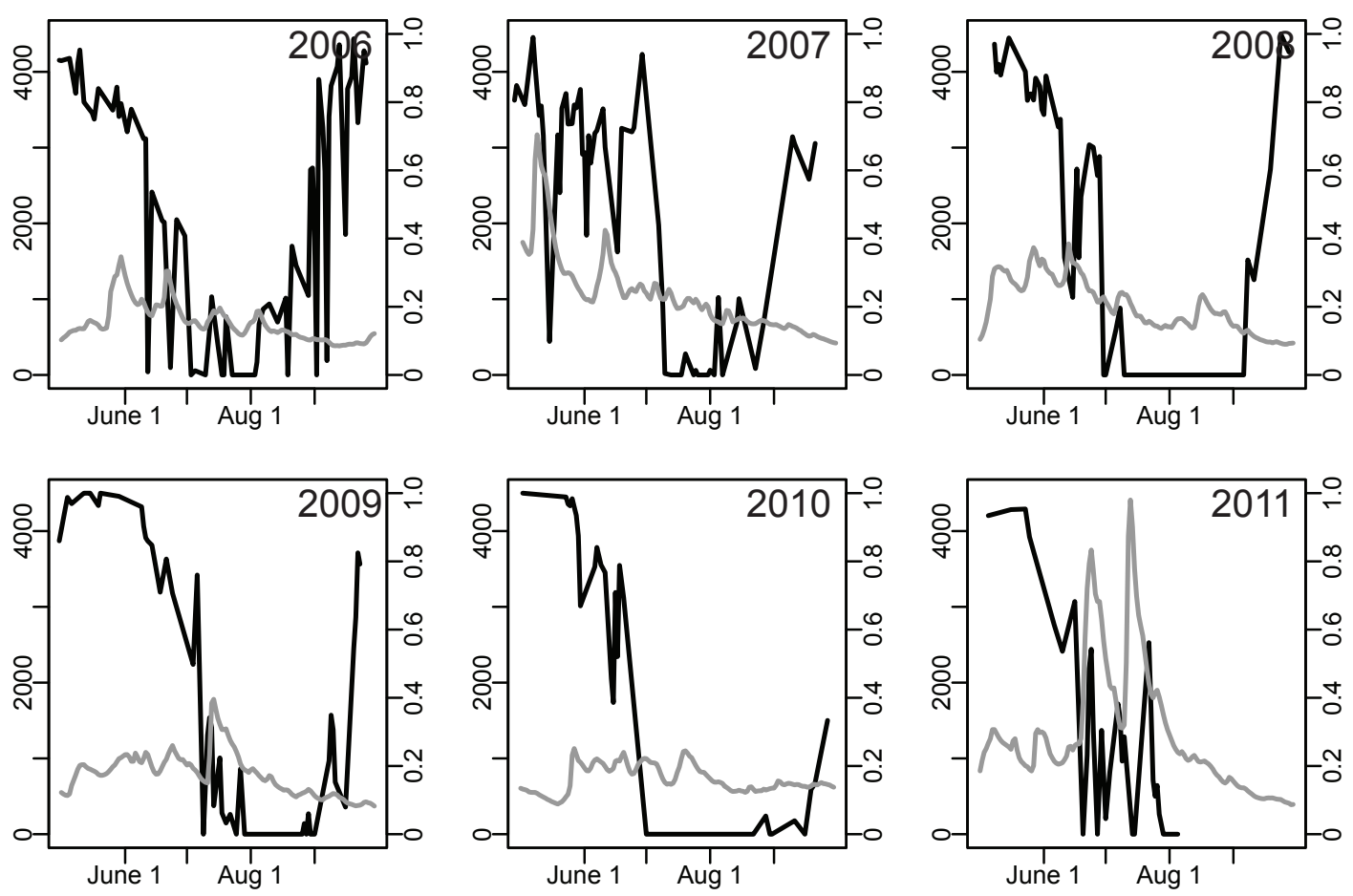

Sediment Area Index

Athabasca River discharge

Annual time series of Athabasca River discharge and remotely sensed sediment area index (proportion of lake area with high sediment water) for Lake 6 (Flour Bay) 
Appendix 4: Select additional sediment maps and MODIS images
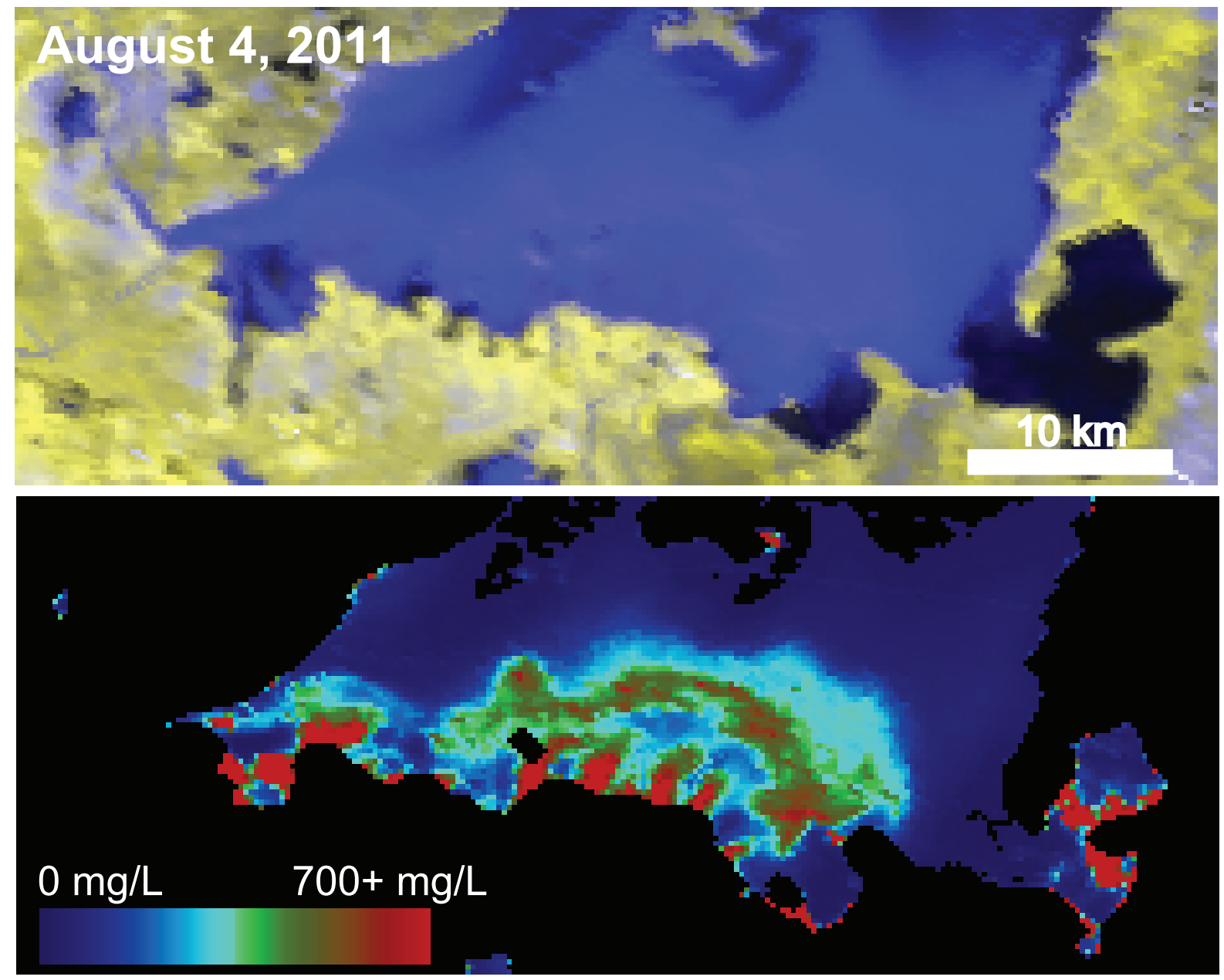

False color MODIS image and corresponding sediment map showing input of sediment laden Athabasca River water. 

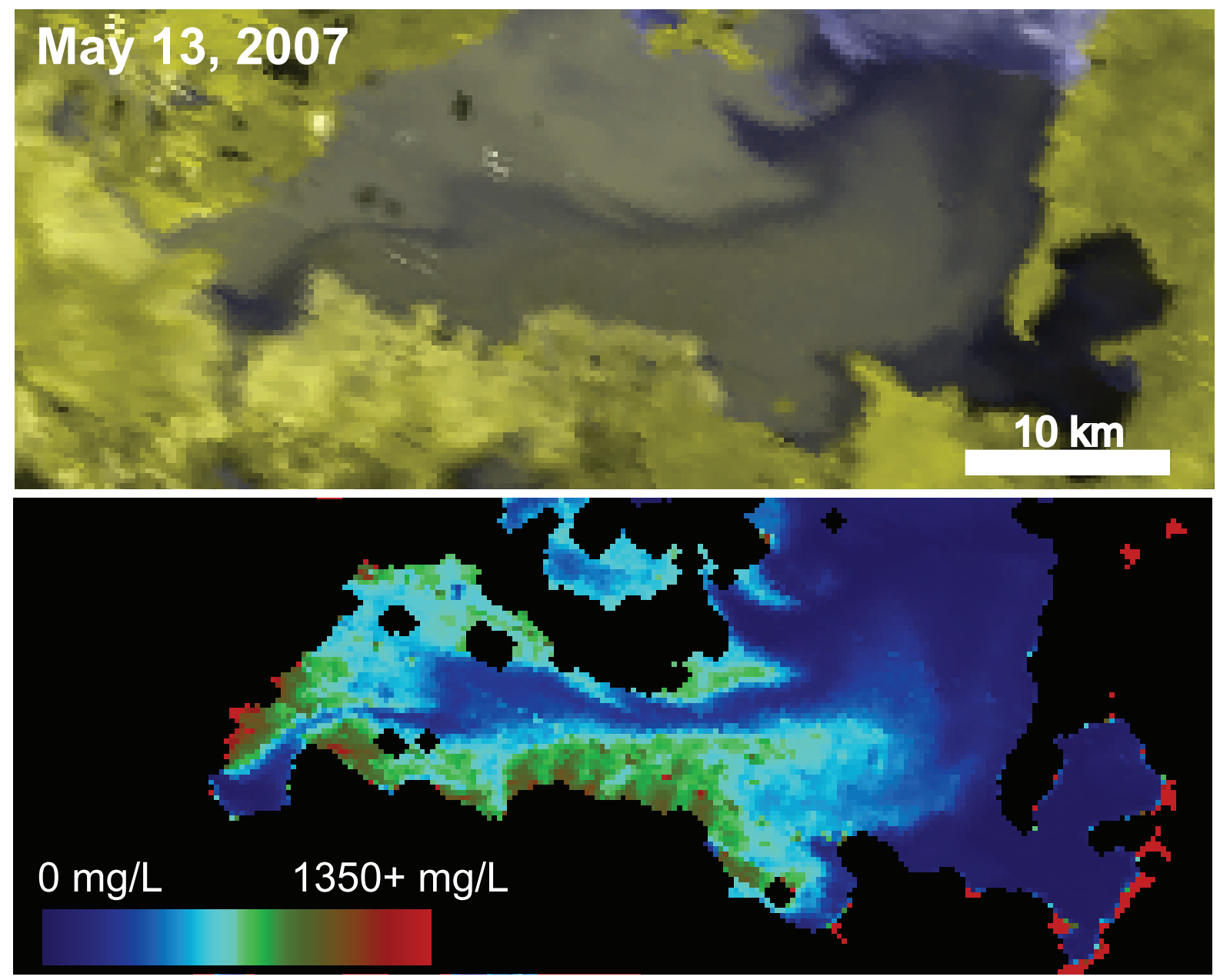

False color MODIS image and corresponding sediment map showing water input from both the Peace River and the Athabasca River. 

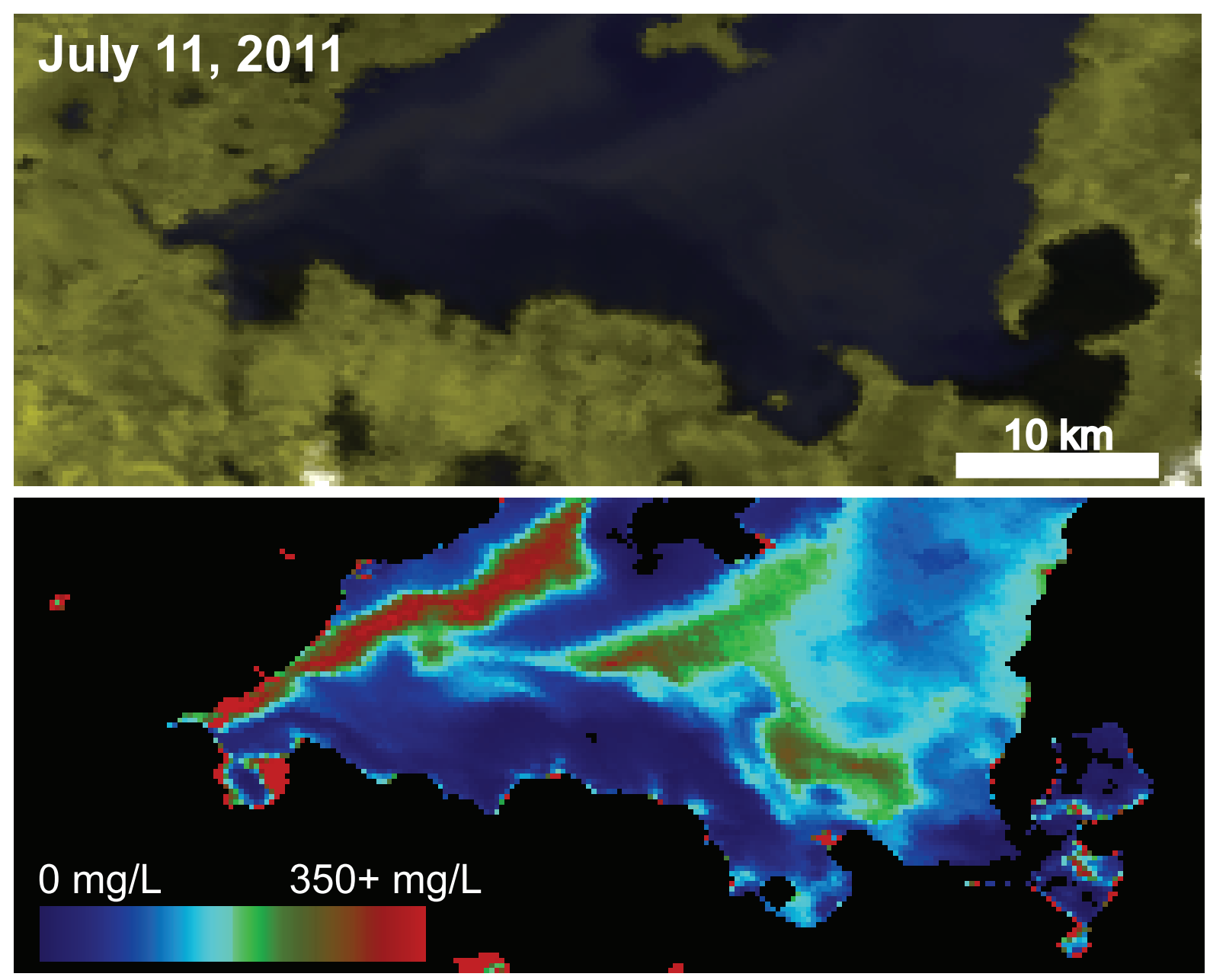

False color MODIS image and corresponding sediment map showing input of sediment laden Peace River water. 


\section{References}

Ali, G. A., \& Roy, A. G. (2010). Shopping for hydrologically representative connectivity metrics in a humid temperate forested catchment. Water Resour. Res., 46(12), W12544. doi: 10.1029/2010wr009442

Andrishak, R., \& Hicks, F. (2011). Ice effects on flow distributions within the Athabasca Delta, Canada. River Research and Applications, 27(9), 1149-1158. doi: 10.1002/rra.1414

Aranuvachapun, S., \& Walling, D. E. (1988). Landsat-MSS radiance as a measure of suspended sediment in the Lower Yellow River (Hwang Ho). Remote Sensing of Environment, 25(2), 145-165. doi: 10.1016/0034-4257(88)90098-3

Beltaos, S., Prowse, T., Bonsal, B., MacKay, R., Romolo, L., Pietroniro, A., \& Toth, B. (2006a). Climatic effects on ice-jam flooding of the Peace-Athabasca Delta. Hydrological Processes, 20(19), 4031-4050. doi: 10.1002/hyp.6418

Beltaos, S., Prowse, T. D., \& Carter, T. (2006b). Ice regime of the lower Peace River and ice-jam flooding of the Peace-Athabasca Delta. Hydrological Processes, 20(19), 4009-4029. doi: 10.1002/hyp.6417

Bloesch, J. (1995). Mechanisms, measurement and importance of sediment resuspension in lakes. Marine and Freshwater Research, 46(1), 295-304. doi: http://dx.doi.org/10.1071/MF9950295

Bracken, L. J., \& Croke, J. (2007). The concept of hydrological connectivity and its contribution to understanding runoff-dominated geomorphic systems. Hydrological Processes, 21(13), 1749-1763. doi: 10.1002/hyp.6313

Chen, Z., Hu, C., \& Muller-Karger, F. (2007). Monitoring turbidity in Tampa Bay using MODIS/Aqua 250-m imagery. Remote Sensing of Environment, 109(2), 207-220. doi: 10.1016/j.rse.2006.12.019

Chu, V. W., Smith, L. C., Rennermalm, A. K., Forster, R. R., Box, J. E., \& Reehy, N. (2009). Sediment plume response to surface melting and supraglacial lake drainages on the Greenland ice sheet. Journal of Glaciology, 55(194), 1072-1082. doi: $10.3189 / 002214309790794904$

Curran, P. J., \& Novo, E. M. M. (1988). The Relationship Between Suspended Sediment Concentration and Remotely Sensed Spectral Radiance: A Review. Journal of Coastal Research, 4(3), 351-368.

D'Sa, E. J., Miller, R. L., \& McKee, B. A. (2007). Suspended particulate matter dynamics in coastal waters from ocean color: Application to the northern Gulf of Mexico. Geophys. Res. Lett., 34(23), L23611. doi: 10.1029/2007g1031192 
Dekker, A. G., Vos, R. J., \& Peters, S. W. M. (2001). Comparison of remote sensing data, model results and in situ data for total suspended matter (TSM) in the southern Frisian lakes. Science of The Total Environment, 268(1-3), 197-214. doi: 10.1016/s0048-9697(00)00679-3

Doxaran, D., Froidefond, J.-M., \& Castaing, P. (2003). Remote-Sensing Reflectance of Turbid Sediment-Dominated Waters. Reduction of Sediment Type Variations and Changing Illumination Conditions Effects by Use of Reflectance Ratios. Appl. Opt., 42(15), 2623-2634.

Doxaran, D., Froidefond, J.-M., Castaing, P., \& Babin, M. (2009). Dynamics of the turbidity maximum zone in a macrotidal estuary (the Gironde, France): Observations from field and MODIS satellite data. Estuarine, Coastal and Shelf Science, 81(3), 321-332. doi: 10.1016/j.ecss.2008.11.013

Doxaran, D., Froidefond, J.-M., Lavender, S., \& Castaing, P. (2002). Spectral signature of highly turbid waters: Application with SPOT data to quantify suspended particulate matter concentrations. Remote Sensing of Environment, 81(1), 149161. doi: 10.1016/s0034-4257(01)00341-8

Duane Nellis, M., Harrington Jr, J. A., \& Wu, J. (1998). Remote sensing of temporal and spatial variations in pool size, suspended sediment, turbidity, and Secchi depth in Tuttle Creek Reservoir, Kansas: 1993. Geomorphology, 21(3-4), 281-293. doi: $10.1016 / \mathrm{s} 0169-555 \times(97) 00067-6$

Farley, D. W., \& Cheng, H. (1986). Hydraulic Impact of Flow Regulation on the PeaceAthabasca Delta. Canadian Water Resources Journal, 11(1), 26-42. doi: 10.4296/cwrj1101026

Fennessy, M. S., Jacobs, A. D., \& Kentula, M. E. (2004). Review of Rapid Methods for Assessing Wetland Condtion. Washington, D.C.

Fraser, R. N. (1998). Multispectral remote sensing of turbidity among Nebraska Sand Hills lakes. International Journal of Remote Sensing, 19(15), 3011-3016. doi: 10.1080/014311698214406

Han, Z., Jin, Y. Q., \& Yun, C. X. (2006). Suspended sediment concentrations in the Yangtze River estuary retrieved from the CMODIS data. International Journal of Remote Sensing, 27(19), 4329-4336. doi: 10.1080/01431160600658164

Hellweger, F., Miller, W., \& Oshodi, K. (2007). Mapping Turbidity in the Charles River, Boston Using a High-resolution Satellite. Environmental Monitoring and Assessment, 132(1), 311-320. doi: 10.1007/s10661-006-9535-8 
Hernández-Ayón, J. M., amp, x, Galindo-Bect, M. S., Flores-Báez, B. P., \& AlvarezBorrego, S. (1993). Nutrient Concentrations are High in the Turbid Waters of the Colorado River Delta. Estuarine, Coastal and Shelf Science, 37(6), 593-602. doi: 10.1006/ecss.1993.1075

Holyer, R. J. (1978). Toward universal multispectral suspended sediment algorithms. Remote Sensing of Environment, 7(4), 323-338. doi: 10.1016/00344257(78)90023-8

Islam, M. R., Yamaguchi, Y., \& Ogawa, K. (2001). Suspended sediment in the Ganges and Brahmaputra Rivers in Bangladesh: observation from TM and AVHRR data. Hydrological Processes, 15(3), 493-509. doi: 10.1002/hyp.165

Jaques, D. (1989). Topographic mapping and drying trends in the Peace-Athabasca Delta, Alberta, using LANDSAT MSS imagery Ecosat Geobotanical Surveys Inc. for Parks Canada (pp. 33). Wood Buffalo National Park, Fort Smith, Northwest Territories, Canada.

Jencso, K. G., McGlynn, B. L., Gooseff, M. N., Wondzell, S. M., Bencala, K. E., \& Marshall, L. A. (2009). Hydrologic connectivity between landscapes and streams: Transferring reach\&\#8208; and plot\&\#8208;scale understanding to the catchment scale. Water Resour. Res., 45(4), W04428. doi: 10.1029/2008wr007225

Keiner, L. E., \& Yan, X.-H. (1998). A Neural Network Model for Estimating Sea Surface Chlorophyll and Sediments from Thematic Mapper Imagery. Remote Sensing of Environment, 66(2), 153-165. doi: 10.1016/s0034-4257(98)00054-6

Kummu, M., \& Varis, O. (2007). Sediment-related impacts due to upstream reservoir trapping, the Lower Mekong River. Geomorphology, 85(3-4), 275-293. doi: 10.1016/j.geomorph.2006.03.024

Lathrop, R. G., Lillesand, T. M., \& Yandell, B. S. (1991). Testing the utility of simple multi-date Thematic Mapper calibration algorithms for monitoring turbid inland waters. International Journal of Remote Sensing, 12(10), 2045-2063. doi: $10.1080 / 01431169108955235$

Leconte, R., Pietroniro, A., Peters, D. L., \& Prowse, T. D. (2001). Effects of flow regulation on hydrologic patterns of a large, inland delta. Regulated Rivers: Research \& Management, 17(1), 51-65. doi: 10.1002/10991646(200101/02)17:1<51::aid-rrr588>3.0.co;2-v

Lesack, L. F. W., Marsh, P., \& Hecky, R. E. (1998). Spatial and Temporal Dynamics of Major Solute Chemistry Among Mackenzie Delta Lakes. Limnology and Oceanography, 43(7), 1530-1543. 
McGowan, S., Leavitt, P. R., Hall, R. I., Wolfe, B. B., Edwards, T. W. D., KarstRiddoch, T., \& Vardy, S. R. (2011). Interdecadal declines in flood frequency increase primary production in lakes of a northern river delta. Global Change Biology, 17(2), 1212-1224. doi: 10.1111/j.1365-2486.2010.02304.x

Meade, R. H. (1996). River-Sediment Inputs to Major Deltas. In J. D. Milliman \& B. U. Haq (Eds.), Sea-Level Rise and Coastal Subsidence: Causes, Consequences, and Strategies (pp. 63-85). The Netherlands: U.S. Government.

Mertes, L. A. K., Smith, M. O., \& Adams, J. B. (1993). Estimating suspended sediment concentrations in surface waters of the Amazon River wetlands from Landsat images. Remote Sensing of Environment, 43(3), 281-301. doi: 10.1016/00344257(93)90071-5

Miller, R. L., \& McKee, B. A. (2004). Using MODIS Terra $250 \mathrm{~m}$ imagery to map concentrations of total suspended matter in coastal waters. Remote Sensing of Environment, 93(1-2), 259-266. doi: 10.1016/j.rse.2004.07.012

Mouchot, M.-C., Alfoldi, T., DeLisle, D., \& McCullough, G. (1991). Monitoring the Water Bodies of the Mackenzie Delta by Remote Sensing Methods. Arctic, 44(1), 21-28.

Novo, E. M. M., Hansom, J. D., \& Curran†, P. J. (1989). The effect of sediment type on the relationship between reflectance and suspended sediment concentration.

International Journal of Remote Sensing, 10(7), 1283-1289. doi:

10.1080/01431168908903967

Owens, P. N., Batalla, R. J., Collins, A. J., Gomez, B., Hicks, D. M., Horowitz, A. J., . . . Trustrum, N. A. (2005). Fine-grained sediment in river systems: environmental significance and management issues. River Research and Applications, 21(7), 693-717. doi: 10.1002/rra.878

Pavelsky, T. M., \& Smith, L. C. (2008). Remote sensing of hydrologic recharge in the Peace-Athabasca Delta, Canada. Geophys. Res. Lett., 35(8), L08403. doi: $10.1029 / 2008 \mathrm{~g} 1033268$

Pavelsky, T. M., \& Smith, L. C. (2009). Remote sensing of suspended sediment concentration, flow velocity, and lake recharge in the Peace-Athabasca Delta, Canada. Water Resour. Res., 45(11), W11417. doi: 10.1029/2008wr007424

Peace-Athabasca Delta Project Group (1973). Technical report: A report on low water levels in Lake Athabasca and their effect on the Peace-Athabasca Delta (pp. 176). Ottawa, Canada.

Pereira, W. E., Domagalski, J. L., Hostettler, F. D., Brown, L. R., \& Rapp, J. B. (1996). Occurrence and accumulation of pesticides and organic contaminants in river 
sediment, water and clam tissues from the san Joaquin River and tributaries, California. Environmental Toxicology and Chemistry, 15(2), 172-180. doi: 10.1002/etc.5620150216

Peters, D. L., \& Prowse, T. D. (2001). Regulation effects on the lower Peace River, Canada. Hydrological Processes, 15(16), 3181-3194. doi: 10.1002/hyp.321

Peters, D. L., Prowse, T. D., Pietroniro, A., \& Leconte, R. (2006). Flood hydrology of the Peace-Athabasca Delta, northern Canada. Hydrological Processes, 20(19), 40734096. doi: 10.1002/hyp.6420

Pringle, C. (2003). What is hydrologic connectivity and why is it ecologically important? Hydrological Processes, 17(13), 2685-2689. doi: 10.1002/hyp.5145

Prowse, T. D., \& Conly, F. M. (2002). A review of hydroecological results of the Northern River Basins Study, Canada. Part 2. Peace-Athabasca Delta. River Research and Applications, 18(5), 447-460. doi: 10.1002/rra.682

Prowse, T. D., \& Demuth, M. N. (1996). USING ICE TO FLOOD THE PEACEATHABASCA DELTA, CANADA. Regulated Rivers: Research \& Management, 12(4-5), 447-457. doi: 10.1002/(sici)1099-1646(199607)12:4/5<447::aidrrr404>3.0.co; $2-\mathrm{y}$

Ritchie, J. C. (2003). Remote sensing techniques to assess water quality. Photogrammetric engineering and remote sensing, 69(6), 695.

Ritchie, J. C., \& Cooper, C. M. (1991). AN ALGORITHM FOR ESTIMATING SURFACE SUSPENDED SEDIMENT CONCENTRATIONS WITH LANDSAT MSS DIGITAL DATA1. JAWRA Journal of the American Water Resources Association, 27(3), 373-379. doi: 10.1111/j.1752-1688.1991.tb01436.x

Ritchie, J. C., Schiebe, F. R., \& McHenry, R. (1976). Remote sensing of suspended sediment in surface waters. Photogrammetric engineering and remote sensing, 69(6), 695-7014.

Ritchie, J. C., \& Zimba, P. V. (2006). Estimation of Suspended Sediment and Algae in Water Bodies Encyclopedia of Hydrological Sciences: John Wiley \& Sons, Ltd.

Schiebe, F. R., Harrington, J. A., \& Ritchie, J. C. (1992). Remote sensing of suspended sediments: the Lake Chicot, Arkansas project. International Journal of Remote Sensing, 13(8), 1487-1509. doi: 10.1080/01431169208904204

Schindler, D. W. (2001). The cumulative effects of climate warming and other human stresses on Canadian freshwaters in the new millennium. Canadian Journal of Fisheries and Aquatic Sciences, 58(1), 18-29. 
Schindler, D. W., \& Donahue, W. F. (2006). An impending water crisis in Canada's western prairie provinces. Proceedings of the National Academy of Sciences, 103(19), 7210-7216. doi: 10.1073/pnas.0601568103

Schindler, D. W., \& Smol, J. P. (2006). Cumulative Effects of Climate Warming and Other Human Activities on Freshwaters of Arctic and Subarctic North America. AMBIO: A Journal of the Human Environment, 35(4), 160-168. doi: 10.1579/0044-7447(2006)35[160:ceocwa]2.0.co;2

Smith, L. C., \& Alsdorf, D. E. (1998). Control on sediment and organic carbon delivery to the Arctic Ocean revealed with space-borne synthetic aperture radar: Ob' River, Siberia. Geology, 26(5), 395-398. doi: 10.1130/00917613(1998)026<0395:cosaoc $>2.3 . c 0 ; 2$

Smith, L. C., \& Pavelsky, T. M. (2009). Remote sensing of volumetric storage changes in lakes. Earth Surface Processes and Landforms, 34(10), 1353-1358. doi: 10.1002/esp. 1822

Song, K., Wang, Z., Blackwell, J., Zhang, B., Li, F., Zhang, Y., \& Jiang, G. (2011). Water quality monitoring using Landsat Themate Mapper data with empirical algorithms in Chagan Lake, China. Journal of Applied Remote Sensing, 5, 053506-053516.

Spearman, C. (1904). The Proof and Measurement of Association between Two Things. The American Journal of Psychology, 15(1), 72-101.

Sterckx, S., Knaeps, E., Bollen, M., Trouw, K., \& Houthuys, R. (2007). Retrieval of Suspended Sediment from Advanced Hyperspectral Sensor Data in the Scheldt Estuary at Different Stages in the Tidal Cycle. Marine Geodesy, 30(1-2), 97-108. doi: 10.1080/01490410701296341

Syvitski, J. (2008). Deltas at risk. Sustainability Science, 3(1), 23-32. doi: $10.1007 / \mathrm{s} 11625-008-0043-3$

Syvitski, J. P. M., Kettner, A. J., Overeem, I., Hutton, E. W. H., Hannon, M. T., Brakenridge, G. R., . . Nicholls, R. J. (2009). Sinking deltas due to human activities. [10.1038/ngeo629]. Nature Geosci, 2(10), 681-686. doi: http://www.nature.com/ngeo/journal/v2/n10/suppinfo/ngeo629_S1.html

Syvitski, J. P. M., Vörösmarty, C. J., Kettner, A. J., \& Green, P. (2005). Impact of Humans on the Flux of Terrestrial Sediment to the Global Coastal Ocean. Science, 308(5720), 376-380. doi: 10.1126/science.1109454

Timoney, K. (2006). Landscape cover change in the Peace-Athabasca Delta, 1927-2001. Wetlands, 26(3), 765-778. doi: 10.1672/0277-5212(2006)26[765:lccitp]2.0.co;2 
Topliss, B. J., Almos, C. L., \& Hill, P. R. (1990). Algorithms for remote sensing of high concentration, inorganic suspended sediment. International Journal of Remote Sensing, 11(6), 947-966. doi: 10.1080/01431169008955069

Töyrä, J., \& Pietroniro, A. (2005). Towards operational monitoring of a northern wetland using geomatics-based techniques. Remote Sensing of Environment, 97(2), 174191. doi: $10.1016 /$ j.rse.2005.03.012

Vörösmarty, C. J., Meybeck, M., Fekete, B., Sharma, K., Green, P., \& Syvitski, J. P. M. (2003). Anthropogenic sediment retention: major global impact from registered river impoundments. Global and Planetary Change, 39(1-2), 169-190. doi: 10.1016/s0921-8181(03)00023-7

Wang, F., Zhou, B., Xu, J., Song, L., \& Wang, X. (2009). Application of neural network and MODIS $250 \mathrm{~m}$ imagery for estimating suspended sediments concentration in Hangzhou Bay, China. Environmental Geology, 56(6), 1093-1101. doi: $10.1007 / \mathrm{s} 00254-008-1209-0$

Wass, P. D., Marks, S. D., Finch, J. W., Leeks, G. J. L., \& Ingram, J. K. (1997). Monitoring and preliminary interpretation of in-river turbidity and remote sensed imagery for suspended sediment transport studies in the Humber catchment. Science of The Total Environment, 194-195(0), 263-283. doi: 10.1016/s00489697(96)05370-3

Wiklund, J. A., Hall, R. I., \& Wolfe, B. B. (2011). Timescales of hydrolimnological change in floodplain lakes of the Peace-Athabasca Delta, northern Alberta, Canada. Ecohydrology, n/a-n/a. doi: 10.1002/eco.226

Wolfe, B. B., Karst-Riddoch, T. L., Hall, R. I., Edwards, T. W. D., English, M. C., Palmini, R., . . Vardy, S. R. (2007). Classification of hydrological regimes of northern floodplain basins (Peace-Athabasca Delta, Canada) from analysis of stable isotopes $(\delta 18 \mathrm{O}, \delta 2 \mathrm{H})$ and water chemistry. Hydrological Processes, $21(2)$, 151-168. doi: 10.1002/hyp.6229

Yang, S. L., Belkin, I. M., Belkina, A. I., Zhao, Q. Y., Zhu, J., \& Ding, P. X. (2003). Delta response to decline in sediment supply from the Yangtze River: evidence of the recent four decades and expectations for the next half-century. Estuarine, Coastal and Shelf Science, 57(4), 689-699. doi: 10.1016/s0272-7714(02)00409-2 